\title{
CONSUMO DE ÁGUA DA CULTURA DA ESTÉVIA (Stevia rebaudiana (Bert.) Bertoni) ESTIMADO POR MICROLISÍMETRO AUTOMÁTICO
}

\author{
DINIZ FRONZA
}

\begin{abstract}
Tese apresentada à Escola Superior de Agricultura "Luiz de Queiroz", Universidade de São Paulo, para a obtenção do título de Doutor em Agronomia, Área de Concentração: Irrigação e Drenagem.
\end{abstract}

\section{PIRACICABA \\ Estado de São Paulo - Brasil}

Fevereiro - 2002 


\title{
CONSUMO DE ÁGUA DA CULTURA DA ESTÉVIA (Stevia rebaudiana (Bert.) Bertoni) ESTIMADO POR MICROLISÍMETRO AUTOMÁTICO
}

\author{
DINIZ FRONZA \\ Engenheiro Agrônomo
}

Orientador: Prof. Dr. MARCOS VINÍCIUS FOLEGATTI

Tese apresentada à Escola Superior de Agricultura "Luiz de Queiroz", Universidade de São Paulo, para a obtenção do título de Doutor em Agronomia, Área de Concentração: Irrigação e Drenagem.

\author{
PIRACICABA \\ Estado de São Paulo - Brasil \\ Fevereiro - 2002
}




\title{
Dados I nternaci onai s de Catal ogação na Publ i cação ( CI P) DI VI SÃo DE BI BLI OTECA E DOCUMENTAÇÃO - ESALQ/ USP
}

\author{
Fronza, Diniz \\ Consumo de água da cultura da estévia (Stevia rebaudiana (Bert.) Bertoni) estimado \\ por microlisímetro automático / Diniz Fronza. - - Piracicaba, 2002. \\ 109 p. : il. \\ Tese (doutorado) - Escola Superior de Agricultura Luiz de Queiroz, 2002. \\ Bibliografia. \\ 1. Balanço hidríco 2. Consumo de água 3. Estévia 4. Irrigação localizada 5. Lençois \\ freáticos 6. Máquinas agrícolas I. Título
}

CDD 633.6

"Permitida a cópia total ou parcial deste documento, desde que citada a fonte - $\mathrm{O}$ autor" 
A meus pais, Lodovico e Dometilda,

e irmãos Dirceu, Dionísio, Dilson, Lisete e Dimas

\section{DEDICO}




\section{AGRADECIMENTOS}

$\mathrm{O}$ autor deixa aqui registrado o seu reconhecimento a todas as pessoas e instituições que, de alguma forma contribuíram para a realização deste trabalho, em especial:

A Universidade Federal de Santa Maria, através do Colégio Agrícola de Santa Maria e seus servidores, pelo incentivo e liberação para tornar possível a realização deste Doutorado.

À Escola Superior de Agricultura "Luiz de Queiroz", da Universidade de São Paulo (Esalq/USP), pelos ensinamentos, oportunidade e disponibilidade para a execução do referido curso.

À Fundação Coordenação de Aperfeiçoamento de Pessoal de Nível Superior (CAPES), por meio do programa CAPES/PICDT/UFSM pela bolsa de estudo concedida no Brasil e CAPES/USP, bolsa sanduíche no Exterior.

Ao Professor Dr. Marcos Vinícius Folegatti, pela orientação, confiança, incentivo e amizade despendida durante estes 3 anos de convivência.

Aos professores Nilson Augusto Villa Nova, José Antônio Frizzone, Durval Dourado Neto e Paulo Leonel Libardi, pelos ensinamentos e apoio na realização deste curso.

À Universidade de Pisa - Itália, na figura do Laboratório Nacional de Irrigação, vinculado ao Departamento de Agronomia e Gestão do Agroecosistema, por disponibilizar de forma permanente toda a estrutura necessária à realização desta pesquisa.

Ao professor Dr. Pier Gino Megale, pela confiança depositada, oportunidade e apoio permanente durante a realização da pesquisa e ao 
pesquisador Dr. Marcello Bertolacci pelo incentivo, amizade, apoio irrestrito durante todo o período de permanência na Itália.

À todos os colegas de curso e Esalq, em especial: à Eder João Pezzebon, Vanoli Fronza, Luis Carlos Timm, Ricardo Nicolas Zarate Rojas, Juan Sinfloriano Delgado Rojas, Alexandre Cândido Xavier e Luis Geraldo Sorria, pelos debates, trocas de idéias, convivência e grande espírito de coleguismo; aos amigos Francisco José de Oliveira Parise e Magali Tanaka, pela rotineira prestatividade e contribuição na relização da tese.

Ao Sr. Paolo Giovannetti, colaborador técnico do Laboratório Nacional de Irrigação, Departamento de Agronomia e Gestão do Agroecosistema da Universidade de Pisa, idealizador e realizador da montagem e calibração dos microlisímetros; aos servidores: Romano Capelli, Fabrizio Alpigiani, Pier Luigi Grossi e Silvia Tagliacarne pela colaboração durante a execução do experimento.

Aos colegas de pesquisa, Ivan Solinas, José E. P. Peres, Fábio Bonacci, Emiliano Mattano e de convívio em Pisa, Geni Zanol, Fábio Pacciolla, Vito Figliuolo, Andrea Cossu, Antônio Cristian Caddeo, pelo companheirismo e apoio durante a permanência na Itália.

A todos os professores e funcionários do Departamento da Engenharia Rural e da Esalq que contribuíram na realização do curso, em especial: Márcia Cristina Guidi Ganzella, Beatriz Regina Duarte Novaes e Davilmar Colevatti, pela grande prestatividade e disposição. 


\section{SUMÁRIO}

Página

LISTA DE FIGURAS.................................................................... viii

LISTA DE TABELAS ....................................................................... xii

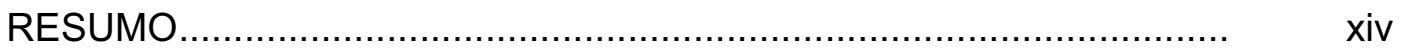

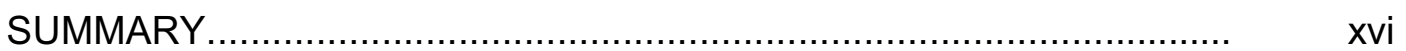

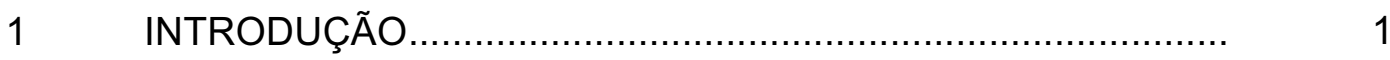

2 REVISÃO DE LITERATURA.................................................

$2.1 \quad$ Uso de edulcorantes..........................................................

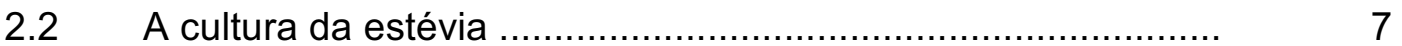

2.2.1 Descrição e distribuição da planta...............................................

2.2.2 Pesquisas e componentes do rendimento............................... 9

2.3 Determinação da evapotranspiração........................................ 11

2.4 Evapotranspiração de referência e coeficiente de cultura.......... 15

2.5 Lisímetros.................................................................... 19

2.6 Microlisímetro de lençol freático constante................................ 21

$3 \quad$ MATERIAL E MÉTODOS....................................................... 26

3.1 Caracterização da área experimental ....................................... 26

3.2 Dados meteorológicos .................................................... 29

3.3 Tratamentos e delineamento experimental ............................. 30

3.4 Descrição e funcionamento do microlisímetro............................ 31

3.5 Instalação e manejo da cultura .............................................

3.6 Irrigações nos diversos tratamentos......................................... $\quad 36$

$3.7 \quad$ Fertirrigação.................................................................. 36

3.8 Avaliação da disponibilidade hídrica........................................ 38

3.9 Análise de crescimento.................................................... $\quad 39$

3.10 Determinação da produção de estévia.................................... 41 
3.11 Análise de esteviosídeo..................................................... 41

3.12 Eficiência do uso da água (EUA).......................................... 42

3.13 Avaliação do sistema de irrigação.......................................... 42

3.14 Controle de pragas, doenças e plantas invasoras ..................... $\quad 43$

3.15 Método Penman-Monteith-FAO................................................. 44

$4 \quad$ RESULTADOS E DISCUSSÃO...............................................

$4.1 \quad$ Consumo hídrico da cultura...................................................... 51

4.2 Evapotranspiração de referência e coeficiente de cultura da

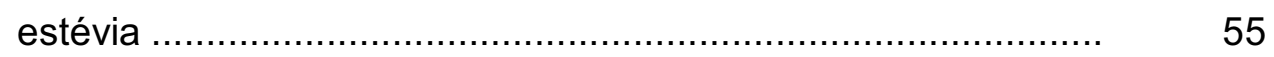

4.3 Resposta da estévia às lâminas de irrigação ............................ 60

4.3.1 Efeito das lâminas totais de água sobre o rendimento de

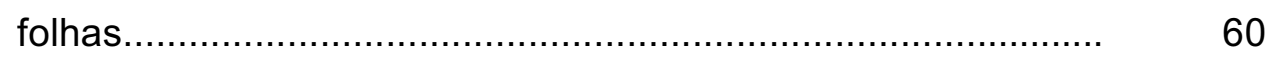

4.3.2 Efeito das lâminas totais de água sobre o índice de área foliar

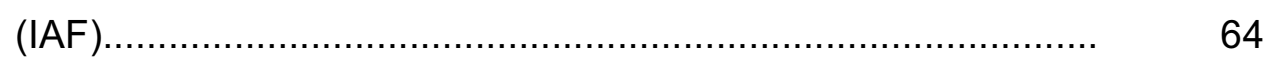

4.3.3 Efeito das lâminas totais de água sobre o número de folhas

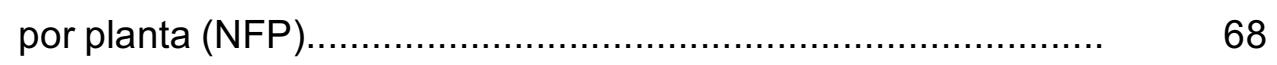

4.3.4 Efeito das lâminas totais de água sobre a relação folha/caule.. 71

4.4 Água disponível no solo e a produtividade................................ 72

4.4.1 Disponibilidade hídrica nos diferentes tratamentos.................... $\quad 72$

4.4.2 Variação da disponibilidade hídrica e intervalos de irrigação ... 77

$4.5 \quad$ Análise de esteviosídeo....................................................... $\quad 80$

4.6 Avaliação do sistema de irrigação............................................. 81

4.7 Rendimento de folhas na segunda colheita.............................. 81

4.8 Considerações sobre o desenvolvimento da cultura................... 83

4.9 Recomendações para futuras pesquisas.................................. 83

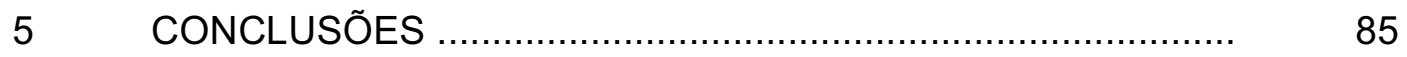

REFERÊNCIAS BIBLIOGRÁFICAS ................................................. 87

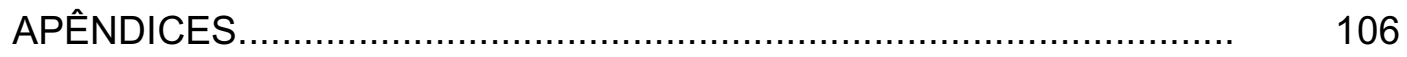




\section{LISTA DE FIGURAS}

Página

1 Localização da cidade de Pisa, Província da Toscana - Itália ......

2 Curva de retenção de água no solo da área experimental

3 Estação Meteorológica de San Piero a Grado - Pisa

29

4 Desenho ilustrativo do microlisímetro de ascensão capilar. Fonte: Laboratório Nacional de Irrigação - Universidade de Pisa .

5 Detalhe do dosador volumétrico hidromecânico de balanço e do contador de pulsos

6 Microbomba de 15 watts e reservatório utilizados para a drenagem e armazenamento do excesso de água dos microlisímetros por ocasião das precipitações

7 Desenho ilustrativo da localização das parcelas de bordaduras, parcelas com os microlisímetros e tratamentos na área experimental

8 Uniformidade das plantas de estévia 15 dias após o corte de uniformização, realizado em 01 de junho de 2.000

9 Sistema de fertirrigação tipo Venturi, distribuição dos 
tensiômetros e microlisímetros no campo experimental .....

10 Detalhe dos tensiômetros instalados na fila, entre plantas da estévia

11 Divisão das 3 classes de tamanho das folhas da estévia, utilizadas para a determinação do índice de área foliar

12 Variação de consumo diário de água, durante o período de cultivo, nos 2 microlisímetros

13 Variação de consumo de água durante o período de cultivo, nos 2 microlisímetros, com dados médios de 5 dias

14 Correlação entre os dados de evapotranspiração real da cultura coletados nos dois microlisímetros

15 Consumo de água medida pelos microlisímetros e ETo estimada por Penman-Monteith para o período de 80 dias

16 Consumo de água e ETo médio para o períodos de 5 dias

17 Variação do coeficiente da cultura $(\mathrm{Kc})$ da estévia ao longo do ciclo

18 Rendimento médio de folhas de estévia em função das lâminas totais de água aplicados

19 Índice de área foliar nos 5 tratamentos e nos microlisímetros em três fases do cultivo da estévia (1 - 25 dias; 2- 50 dias; 3 - 75 dias) 
20 Correlação entre o índice de área foliar e o rendimento da cultura da estévia

21 Índice de área foliar em função das lâminas totais de irrigação ....

22 Visualização da altura das plantas de estévia no momento da colheita e desfolha manual visando a pré-secagem

23 Equação de correlação entre o número de folhas por planta e lâminas totais de irrigação

24 Efeito das lâminas de irrigação no número de folhas por planta durante o período de cultivo da estévia

25 Rendimento relativo de folhas da estévia em função do potencial matricial da água no solo

26 Variação da tensão de água no solo, medida por tensiômetros a $10 \mathrm{~cm}$ de profundidade

27 Variação da tensão de água no solo, medida por tensiômetros a $20 \mathrm{~cm}$ de profundidade

28 Variação da tensão de água no solo, medida por tensiômetros a $30 \mathrm{~cm}$ de profundidade

29 Variação da tensão de água no solo, medida por tensiômetros a $40 \mathrm{~cm}$ de profundidade

30 Tensão de água no solo na zona radicular um dia após as irrigações, na dose de $117 \%$ ETE do microlisímetro. 
31 Tensão de água no solo na zona radicular dois dias após as irrigações, na dose de $117 \%$ ETE do microlisímetro

32 Tensão de água no solo na zona radicular três dias após as irrigações, na dose de $117 \%$ ETE do microlisímetro

33 Tensão de água no solo na zona radicular quatro dias após as irrigações, na dose de 117\% ETE do microlisímetro..................... 


\section{LISTA DE TABELAS}

Página

1 Composição granulométrica e classificação textural do solo

2 Composição química dos nutrientes do solo da área em que foi desenvolvida a pesquisa

4 Análises de algumas características físico-hídricas do solo

5 Duração máxima de horas de insolação forte $(\mathrm{N})$ em diferentes meses do ano, radiação extraterrestre $(\mathrm{Ra})$, em equivalentes de evaporação $\left(\mathrm{mm} \cdot \mathrm{dia}^{-1}\right)$ e energia extraterrestre $(\mathrm{Ee})$ para a região de Pisa - Itália

6 Macronutrientes e micronutrientes $\left(\mathrm{kg} \cdot \mathrm{ha}^{-1}\right)$ exigidos pela cultura da estévia (Lima Filho et al. 1997)

7 Consumo hídrico da cultura da estévia nos microlisímetros $\left(\mathrm{mm} \cdot \mathrm{dia}^{-1}\right)$

8 Consumo médio de água nos microlisímetros, evapotranspiração de referência e Kc médio para períodos de 5 dias 
9 Valores médios de índice de área foliar (aos 25, 50 e 75 dias), número de folhas por planta (NPF) e rendimento de folhas (Rend.), em função das fases da cultura e dos tratamentos irrigados

10 Produção de massa seca de folhas (MSkg.ha-1 ${ }^{-1}$ ), lâmina total de irrigação no ciclo $(\mathrm{mm})$, eficiência do uso da água para produção de folhas $\left(\mathrm{L} . \mathrm{kg}^{-1}\right)$

11 Relações folha/caule e percentagem de matéria seca das folhas (\%MSF), submetida às diferentes lâminas de irrigação

12 Análise quantitativa de esteviosídeo, rebaudiosídeo $A$ e rebaudiosídeo $\mathrm{C}$ (análise HPLC)

13 Rendimento de folhas da cultura da estévia na segunda colheita..

14 Dados meteorológicos coletados em junho de 2000 na área experimental

15 Dados meteorológicos coletados em julho de 2000 na área experimental

16 Dados meteorológicos coletados em agosto de 2000 na área experimental 


\title{
CONSUMO DE ÁGUA DA CULTURA DA ESTÉVIA (Stevia rebaudiana (Bert.) Bertoni) ESTIMADO POR MICROLISÍMETRO AUTOMÁTICO
}

\author{
Autor: DINIZ FRONZA \\ Orientador: Prof. MARCOS VINÍCIUS FOLEGATTI
}

\section{RESUMO}

Este trabalho teve como objetivos estimar o consumo hídrico da cultura da estévia utilizando dois microlisímetros de lençol freático de nível constante, bem como determinar as funções de resposta de lâminas de irrigação no rendimento de folhas da cultura. A pesquisa foi realizada na área experimental do Departamento de Agronomia e Gestão do Agroecossistema da Universidade de Pisa, em San Piero a Grado Pisa/Itália. A evapotranspiração de referência foi determinada pelo método Penman-Monteith-FAO. Os dados de evapotranspiração foram coletados diariamente durante o período de junho a outubro de 2000. O lençol freático dos dois microlisímetros foi mantido a $35 \mathrm{~cm}$ da superfície do solo. As lâminas de irrigação aplicadas foram $64 \%, 80 \%, 100 \%, 117 \%$ da evapotranspiração medida pelos microlisímetros e um tratamento testemunha sem irrigação, sendo 4 repetições em cada tratamento. $O$ potencial de água no solo nos tratamentos foi monitorado com tensiômetros instalados nas profundidades de $10 \mathrm{~cm}, 20 \mathrm{~cm}, 30 \mathrm{~cm}$ e $40 \mathrm{~cm}$ de profundidade. A evapotranspiração da cultura durante todo ciclo (80 dias) foi de $464 \mathrm{~mm}$. Os valores médios de evapotranspiração para a fase de maior 
consumo, ou seja, fase final, foram de $5,44 \mathrm{~mm} \cdot \mathrm{dia}^{-1}$. Os valores de coeficiente de cultura foram de 1,45 para a fase inicial, 1,14 para a intermediária e 1,16 para a fase final do desenvolvimento da cultura. $O$ uso das maiores lâminas de irrigação, 117\% ETE (538 mm) e 100\%ETE (464 $\mathrm{mm}$ ) promoveram o maior rendimento de folhas, com $5130 \mathrm{~kg} \cdot \mathrm{ha}^{-1}$ e 4931 kg.ha ${ }^{-1}$, respectivamente. Esses valores foram $113 \%$ e $105 \%$ superiores ao tratamento sem irrigação. $O$ rendimento da cultura decresceu conforme aumentou a tensão de água no solo. $O$ uso das diferentes lâminas de irrigação não afetou o teor de esteviosídeo nas folhas, com um valor médio de $6,49 \%$. O intervalo de irrigação de 3 dias não afetou o rendimento quando foi aplicado a maior lâmina de irrigação (117\%). 


\title{
WATER CONSUMPTION OF ESTEVIA (Stevia rebaudiana (Bert.) Bertoni) ESTIMATE BY AUTOMATIC MICROLYSIMETER
}

\author{
Author: DINIZ FRONZA \\ Adviser: Prof. MARCOS VINÍCIUS FOLEGATTI
}

\section{SUMMARY}

The aim of this work was to estimate the water consumption of stevia using two constant watertable microlysimeters and determine the irrigation levels response in the yield. The research was conducted at the Department of Agronomy and Agroecosystem Gestion experimental area of the Pisa University, in San Piero a Grado -Pisa/Italy. The reference evapotranspiration was determined by the Penman-Monteith-FAO method. The data was daily collected from June to October 2000. The two microlysimeters watertable had been maintained at $35 \mathrm{~cm}$ depth. The irrigation levels were $15 \%, 64 \%$, $80 \%, 100 \%$ and $117 \%$ of evapotranspiration (ETP), measured by capillary ascension microlisymeter. The experimental design was entirely randomized with 4 repetition and 20 plots. The soil water potential was measured by tensiometers installed at $10 \mathrm{~cm}, 20 \mathrm{~cm}, 30 \mathrm{~cm}$ e $40 \mathrm{~cm}$. The crop evapotranspiration in the total cicle (80 days) was $464 \mathrm{~mm}$. For the most water consumption phase, the crop evapotranspiration average was 5,44 mm.day ${ }^{-1}$. The crop coefficient values were 1.45 for the first 25 days, 1.14 for the next period (from 26 to 50 days), and 1.16 for the latest one (from 51 to 80 days). The greatest yield was obtained by $117 \%$ ETE $(538 \mathrm{~mm})$ and $100 \%$ 
ETE (464 mm) irrigation levels, with $5130 \mathrm{~kg} \cdot \mathrm{ha}^{-1}$ and $4931 \mathrm{~kg} \cdot \mathrm{ha}^{-1}$, respectively. Theses values were $113 \%$ and $105 \%$ higher than the treatment without irrigation. The yield decreased according to increased the soil water tension. The different irrigation levels did not affect the steviodeo content, with an average of $6,49 \%$. Until 3 days between irrigation under the $117 \%$ ETE, the crops yield was not affected significatevily. 


\section{INTRODUÇÃO}

A cultura da estévia teve um incremento de cultivo em vários países graças ao glicosídeo extraído de suas folhas (esteviosídeo), cujo poder adoçante é aproximadamente 300 vezes superior ao da sacarose. O produto destaca-se pela ausência de calorias, sendo muito utilizado em dietas especiais, como a dos diabéticos, obesos, etc.

A estévia é cultivada em pequenas áreas agrícolas, sendo uma opção de alta lucratividade por unidade de área. Após 30 anos de exploração econômica, a elevação da rentabilidade é dificultada, dentre outros fatores, pela ausência de informações referentes às exigências hídricas da cultura ao longo das diferentes fases de desenvolvimento.

Cabe ressaltar que entre os fatores climáticos, a precipitação pluviométrica é a que mais freqüentemente tem limitado o rendimento dos cultivos. A flutuação das safras agrícolas, principalmente das culturas de primavera-verão, é dependente do regime de chuvas. Assim, em regiões de insuficiência pluviométrica, tanto no que se refere a quantidade como a distribuição, altos patamares de produtividade dependem da irrigação. Apesar dessa técnica ser muito utilizada, na maioria das vezes, é aplicada de forma incorreta, conseqüentemente com obtenção de baixa produtividade e aumento no custo de produção. O sucesso da agricultura irrigada envolve muito mais que a instalação e operação dos equipamentos de irrigação. Depende principalmente, da quantidade de água aplicada no devido momento requerido pela cultura.

Quando a taxa de absorção de água do solo pelas raízes torna-se 
menor que da transpiração, a taxa de crescimento das plantas é afetada. Isto ocorre, pois as mesmas fecham seus estômatos, evitando perda excessiva de umidade nos tecidos foliares, a entrada de $\mathrm{CO}_{2}$ é reduzida e, conseqüentemente a fotossíntese e o crescimento celular. Deste modo a redução da transpiração está diretamente relacionada ao decréscimo do crescimento e da produção. Fica claro, portanto que a determinação da evapotranspiração (evaporação da água do solo + transpiração das plantas) de uma cultura agrícola é de fundamental importância para a utilização racional dos recursos hídricos na irrigação e também para atingir elevada produtividade dos cultivos. Essa evapotranspiração, ocorre de forma variada durante o ciclo, sendo influenciada pelas condições edafoclimáticas locais.

O estudo da evaporação e transpiração têm sido alvo de muitos pesquisadores em diferentes regiões de cultivo e recorrendo-se a diferentes metodologias. Estas possuem características que podem se adaptar melhor a determinadas condições ou apresentar limitações devido a exigências de variáveis necessárias ou condições particulares de funcionamento. Um fator que tem intrigado os pesquisadores é que na aplicação de diferentes metodologias sob as mesmas condições, os resultados encontrados, muitas vezes, têm variado dependendo do método empregado. Este fato tem estimulado estudos visando ajustar os métodos e avaliá-los objetivando estimativas mais precisas.

Apesar do nível tecnológico dos equipamentos de irrigação ter avançado consideravelmente, este progresso ainda não é plenamente aproveitado devido ao nível de conhecimento dos produtores, políticas agrícolas ineficientes e, principalmente ao manejo da irrigação equivocado durante as diferentes fases de desenvolvimento das culturas. Existem vários métodos para estimar o consumo hídrico de uma cultura. Entre eles, os lisímetros têm demostrado serem melhores para a obtenção da evapotranspiração real da cultura com elevada precisão. A maioria dos lisímetros fornece dados de evapotranspiração precisos para períodos de 7 a 10 dias (lisímetros de não- 
pesagem), ou seja, não são eficientes para dados diários. Outros lisímetros (de pesagem), com alta precisão, inclusive horária, apresentam elevado custo e grande dificuldade de instalação em cultivos comerciais, por exigirem um alto nível de conhecimento do agricultor.

Alguns países, buscando alternativas simples para a determinação da demanda hídrica de uma cultura e seu coeficiente de cultura, utilizam lisímetros de nível freático constante. Nesse sentido, o Laboratório Nacional de Irrigação (Pisa - Itália) testou durante 10 anos um microlisímetro de lençol freático constante de baixo custo de instalação e alta praticidade. Instalado diretamente no campo, ele permite a obtenção de dados de evapotranspiração diários e também a tomada de decisão quanto à dose e momento da irrigação (Grossi et al.,1990; Bertolacci \& Megale, 1999; Pardossi et al. 1993).

Mediante o exposto, o objetivo deste trabalho foi estimar o consumo hídrico da cultura da estévia por meio do uso de microlisímetros de ascensão capilar (com nível do lençol freático constante). Com os dados de consumo hídrico e de evapotranspiração de referência calculado através de PenmanMonteith-FAO, foi determinado o Kc para três fases da cultura.

Neste trabalho, foi verificado também a resposta da cultura a diferentes lâminas de irrigação fornecidas, bem como sua interferência na variação do teor de esteviosídeo em função da água disponível no solo. 


\section{REVISÃO DE LITERATURA}

\subsection{Uso de edulcorantes}

Nos últimos anos, tem-se observado grande procura por alimentos de baixa caloria ou mesmo não calórico. Muito provavelmente uma conseqüência dos hábitos muito mais sedentários, seja em função da vida profissional ou descuido com as necessidades de exercícios, essenciais ao organismo, ou pela desproporcional ingestão de alimentos energéticos, que causam acúmulos, prejudiciais à saúde humana.

O estudo de adoçantes utilizados na formulação de alimentos dietéticos, bem como medicamentos, teve significativo aumento na última década. Tal fato pode ser justificado pelo consumo crescente desses produtos na busca de proporcionar uma melhor saúde humana. Por sua vez, pesquisas visam também encontrar adoçantes com gosto semelhante ao da sacarose, que sejam de baixo custo e não forneçam calorias ao organismo.

Os adoçantes dietéticos são, em sua maioria, compostos a partir de substâncias não calóricas, naturais ou sintéticas, conhecidas como edulcorantes. Estes edulcorantes são mais doces que o açúcar branco e responsáveis pelo sabor dos adoçantes de mesa (Angelucci, 1986).

A maioria dos edulcorantes têm o inconveniente de apresentarem um ligeiro sabor residual desagradavelmente amargo após a ingestão. Nesse sentido, as indústrias estão buscando mais alternativas para possibilitar ao paciente desfrutar o sabor dos alimentos sem precisar sair da dieta. Normalmente, recorre-se a uma combinação de 2 ou 3 edulcorantes.

No Brasil, os edulcorantes aprovados pela Agência Nacional de 
Vigilância Sanitária (ANVISA), para uso em adoçantes dietéticos não calóricos, são: a sacarina, o ciclamato, o aspartame, o acesulfame-k, a sucralose e o esteviosídeo. A seguir são descritas as características principais desses adoçantes (Cidade do Diabético, 2001).

A sacarina tem poder adoçante 500 vezes maior do que a sacarose. Em altas concentrações deixa um sabor residual amargo e não é metabolizado pelo organismo. Trata-se de um substância de fácil solubilidade e estável em altas temperaturas. Sua ingestão diária aceitável (IDA) é correspondente a 5 $\mathrm{mg} \cdot \mathrm{kg}^{-1}$ de peso corpóreo.

Já, o ciclamato é outro edulcorante artificial largamente utilizado no setor alimentício, sendo aplicado em adoçantes de mesa, bebidas dietéticas, geléias, sorvetes, gelatinas, etc. Com o menor poder adoçante entre os edulcorantes, é 40 vezes mais doce que a sacarose. Não calórico, possui sabor agradável e semelhante ao açúcar refinado (apresentando um leve gosto residual). Não é metabolizado pelo organismo, nem perde a doçura quando submetido a altas ou baixas temperaturas e a meios ácidos. Apresenta IDA correspondente a $11 \mathrm{mg} \cdot \mathrm{kg}^{-1}$ de peso corpóreo.

O aspartame possui sabor agradável e semelhante ao açúcar branco. Como seu potencial adoçante é 200 vezes maior, permite o uso em pequenas quantidades. Seu valor energético corresponde a 4 calorias por grama. É muito utilizado pela indústria alimentícia, principalmente nos refrigerantes diet. Sensível ao calor, perde o seu poder de adoçamento em altas temperaturas. Também, a capacidade adoçante poderá diminuir quando estiver armazenado por muito tempo. É contra-indicado aos portadores de fenilcetonúria, uma doença genética rara que provoca o acúmulo da fenilalanina no organismo, causando retardo mental. Sua IDA é correspondente a $40 \mathrm{mg} \cdot \mathrm{kg}^{-1}$ de peso corpóreo.

O acesulfame-k é o adoçante sintético de maior resistência ao armazenamento prolongado e a diferentes temperaturas. Adoça 200 vezes mais que a sacarose e seu gosto doce é percebido de imediato. Em grandes doses 
deixa um leve sabor residual amargo. Não é calórico e nem metabolizado pelo organismo. Devido a suas características, pode ser utilizado tanto como adoçante de mesa, como numa infinidade de produtos. Embora seja rapidamente absorvida, 99 \% da substância é eliminada em 24 horas pela urina de forma inalterada. Vários estudos demonstraram ausência de indícios cancerígenos ou mutações na célula. Apresenta IDA correspondente a 15 $\mathrm{mg} \cdot \mathrm{kg}^{-1}$ de peso corpóreo.

Por sua vez, a sucralose é um edulcorante sintético com poder adoçante 600 vezes maior do que a sacarose. Não é calórico e possui sabor agradável. Também não é metabolizada pelo organismo, sendo eliminada por completo em 24 horas pela urina. É estável a temperaturas altas e baixas e por longos períodos de armazenamento. Pode ser usada como adoçante de mesa, em formulações secas (como refrescos e sobremesas instantâneas), em aromatizantes, conservantes, temperos, molhos prontos, compotas, etc. Não produz cáries, além de reduzir a produção de ácidos responsáveis pela sua formação. Apresenta IDA correspondente a $15 \mathrm{mg} \cdot \mathrm{kg}^{-1}$ de peso corpóreo.

Ao passo que a Stevia rebaudiana (BERT.) foi classificada por Bertoni em 1905, é muito difundida no Japão. Das suas folhas se extrai o esteviosídeo, edulcorante natural de sabor doce retardado com poder adoçante 300 vezes maior do que a sacarose. Tem boa estabilidade tanto em altas como em baixas temperaturas. Pode ser consumida sem nenhuma contra-indicação por qualquer pessoa. Não produz cáries, nem é calórica, tóxica, fermentável ou metabolizada pelo organismo. Sua IDA é correspondente a $5,5 \mathrm{mg} \cdot \mathrm{kg}^{-1}$ de peso corpóreo.

Conforme Freitas (1999), os edulcorantes mais utilizados atualmente são: a sacarina, o ciclamato, o aspartame e o esteviosídeo. A autora também aborda alguns aspectos desses adoçantes, descritas a seguir. A sacarina apresenta baixo custo, não contém calorias, não afeta os dentes e apresenta estabilidade a uma faixa ampla de aplicações. No entanto, tem como inconveniente conferir um gosto amargo residual após o consumo. O ciclamato 
tem maior custo mas reduz o gosto amargo quando associado à sacarina. Geralmente, eles são utilizados de forma conjunta. Já, o aspartame fornece baixa quantidade de calorias $\left(4 \mathrm{Kcal}^{-1} \mathrm{~g}^{-1}\right.$ ). Ele apresenta alta solubilidade em água, porém, é insolúvel em óleos e gorduras. Alguns autores afirmam que, sob temperaturas elevadas, seus componentes são desestabilizados e podem se tornar tóxicos.

Existem poucos edulcorantes de origem natural que são permitidos e utilizados como substitutos da sacarose. Dentre esses, destaca-se o extrato de folhas de estévia, composto por glicosídeos terpênicos. É o único edulcorante natural, não calórico, totalmente produzido no Brasil. O extrato puro é um pó branco, formado por cristais adoçantes de estévia, cujos princípios ativos encontrados são: esteviosídeo, rebaudiosídeo $A, B, C, D$ e $E$ e dulcosídeo $A$. Os mesmos não possuem calorias e sua aplicação é feita em bebidas com baixo valor calórico, na indústria de alimentos enlatados, nos biscoitos, nos doces e nas gomas de mascar. O esteviosídeo é o edulcorante de maior teor nas folhas de estévia (5-15\% em peso seco) seguido do rebaudeosídeo A (3$6 \%$ em peso seco) (Sakaguchi \& Kan, 1982). Os estudos mais avançados, bem como o seu uso mais amplo, ocorrem no Japão desde os anos 70 (Cardello et al., 2000). A permissão de seu uso no Brasil, como adoçante em bebidas e alimentos, foi oficializada em 1988 (ABIA, 1991). Os adoçantes extraídos substituem os açúcares convencionais ou dietéticos artificiais em muitos alimentos líquidos e sólidos, sendo muito utilizados, principalmente, no Japão, Coréia, Canadá, Tailândia, Brasil e Paraguai (Manara et al., 1986, Risaliti et al., 1997). A planta tem sido consumida como diurético, antidiabético e no auxilio no tratamento contra a obesidade (substitui o açúcar de cana).

\subsection{A Cultura da estévia}

\subsubsection{Descrição e distribuição da planta}

Como já foi mencionado anteriormente, a estévia (Stevia rebaudiana 
Bert.) possui propriedades edulcorantes 300 a 400 vezes maiores que o açúcarde-cana. Inicialmente, esta capacidade foi atribuída ao esteviosídeo (Fellipe, 1977). Após a década de 1970, outros compostos com propriedades edulcorantes foram extraídos e identificados (Handro \& Ferreira, 1989).

A estévia é uma planta herbácea perene, pertencente à família das Compositae. É um sub-arbusto ereto que chega até $1 \mathrm{~m}$ de altura. Possui folhas opostas, subsésseis, ovado-oblongas, obtusas, com até $6 \mathrm{~cm}$ de comprimento. Tem sido utilizada pelos índios Guaranis como adoçantes de bebidas, especialmente no mate cozido. Esta planta é conhecida na linguagem Guarani como "Kaá-hê-é" ou Caá Hê-é (erva-doce), "ca-a-yupè" (doce), "azucà-caà (erva de açúcar), ou nomes similares que tem o significado de erva doce (Monteiro, 1982; Soejardo, 1983; Alvarez, 1984,).

A planta é originalmente encontrada em regiões de clima tropical, entre $22^{\circ}$ a $25^{\circ}$ de latitude sul e $54^{\circ}$ a $56^{\circ}$ de longitude oeste de Greenwich. Esta região compreende o leste do Paraguai, Cordilheira do Amanbaí e Oeste do Brasil, entre Paraná e Mato Grosso do Sul (Alvarez, 1984; Monteiro, 1986; Bertonha et al., 1984).

Desde o século XIX encontram-se referências na literatura sobre o poder edulcorante dessa espécie (Lewis,1992; Carvalho \& Zaidan, 1995). Os primeiros relatos formais da planta foram feitos em 1899, por Moisés S. Bertoni, um naturalista paraguaio, que obteve referências sobre a planta de ervateiros e índios no leste do Paraguai (Bertoni, 1899; 1927).

Segundo trabalho realizado por Valio \& Rocha (1977), a estévia é uma planta de dias curtos para florescimento, com comprimento de dia crítico de 12 a 13 horas, com pequenas variações por ecotipos. Dois a três dias curtos são suficientes para induzirem a floração. Ainda, Metiver \& Viana (1979), relatam que, quando as plantas são submetidas a fotoperíodo de 16 horas, desenvolvem maior comprimento de entrenós, maior área foliar, maior produção de massa seca, maior velocidade de emissão de folhas e maior conteúdo foliar de açúcares solúveis, proteínas, esteviosídeo e esteviol, quando comparadas 
com plantas submetidas a oito horas de luz.

Em condições naturais paraguaias, a principal época de floração é entre outubro e novembro (Fellipe, 1977). Quando a planta possui quatro pares de folhas, está fisiologicamente preparada para receber estímulos que induzem o florescimento (Viana \& Metivier, 1980; Carneiro, 1990).

A propagação da estévia pode ser feita por via sexual ou assexual. A propagação sexual é dificultada em função do baixo período de viabilidade das sementes, menor de 8 meses, e do alto percentual de frutos estéreis, entre 80 a 90\% (Fellipe \& Lucas, 1971; Rocha \& Válio, 1972; Randi \& Fellipe, 1981). Por outro lado, a reprodução vegetativa por meio de enraizamento de estacas é relativamente fácil (Carvalho \& Zaidan, 1995). Segundo Handro \& Kerbauy (1975), a propagação por cultura de tecidos, utilizando discos foliares, é outra possibilidade para a implantação comercial da estévia.

A planta possui sistema radicular pivotante no início do desenvolvimento. Após o primeiro corte, ocorre uma diferenciação celular na região do coleto e o sistema radicular torna-se fasciculado, com maior distribuição na camada superficial do solo. Ainda, seu crescimento é determinado e a altura da planta é influenciada pela época de transplantio ou corte, do local e produção, da idade das plantas e adubação utilizada, podendo atingir até um metro (Bertonha, 1986; Carneiro, 1990). Após cada corte, ocorre a diminuição dos ramos secundários até que cada perfilho tenha somente a haste principal, porém o número de perfilhos aumenta consideravlmente.

\subsubsection{Pesquisas e componentes do rendimento}

Como citado anteriormente, a preocupação com o uso de adoçantes não calóricos, ocasionou um incremento no interesse em estudar técnicas de cultivo e extração dos elementos adoçantes da estévia (Tateo et al. 1998; Cardello et al., 2000; Brandle \& Rosa, 1998). Vários países estão cultivando a

estévia comercialmente. No entanto, os artigos científicos que estudaram a 
importância do fator água na produção da massa seca de folhas e, conseqüentemente, de adoçante, são poucos ou inexistentes (Bertonha et al. 2000; Risaliti et al. 1997).

O cultivo da estévia sob irrigação tem apresentado produtividade de até $3.000 \mathrm{~kg} \cdot \mathrm{ha}^{-1}$ anuais. Tal produtividade pode ser considerada baixa, comparando-se ao potencial da cultura (Bertonha et al. 2000). A irrigação tem aumentado tanto a produção de massa seca, como também afeta positivamente o vigor e a velocidade de rebrota da planta após cada colheita. Ainda não existem parâmetros definidos relacionados à quantidade de água de irrigação em cada uma das fases fenológicas, nível de exigência de água disponível no solo e produtividade em função do método de irrigação aplicado. O conhecimento destes fatores implicaria em redução dos custos e melhor aproveitamento dos recursos hídricos (González, 2000; Frizone, 1986).

Apesar da estévia ser cultivada há mais de 20 anos de forma comercial, poucos são os produtores que recorrem à irrigação por gotejamento, técnica que permite o uso da fertirrigação. Essa técnica é muito aplicada em cultivos de alta resposta financeira por unidade de área. Como principais vantagens da fertirrigação destacam-se: economia de mão-de-obra e energia, possibilidade de aplicar fertilizantes em qualquer fase do ciclo da cultura, fácil parcelamento dos fertilizantes e maior eficiência na utilização dos nutrientes pelas culturas, maior eficiência de uso da água e menor incidência de doenças (Vermeiren \& Joblin, 1980; Folegatti, 1999). A considerável resposta econômica por hectare ao ano da estévia (U\$ 2.000,00 a 5.000,00) justifica investigações científicas empregando a técnica da fertirrigação. Ademais, destaca-se o fato de ser uma cultura onde há o predomínio de pequenos produtores, com áreas que necessitam cultivos e/ou criações de elevado retorno financeiro, que permitam a digna subsistência.

Em trabalho realizado por Bertonha et al. (2000), mantendo-se o cultivo com a disponibilidade hídrica ao potencial de água no solo de $117,5 \mathrm{kPa}$, concluiu-se que é possível obter uma produtividade acima de $7.000 \mathrm{~kg}^{-\mathrm{ha}^{-1}}$ ao 
ano. Trata-se de 2,5 vezes superior à média obtida na região de maior produção (Oeste do Paraná). Ainda, foi encontrado no mesmo trabalho efeitos semelhantes da disponibilidade de água sobre a produção de massa seca da planta e açúcares nas folhas.

Experimentos realizados na Universidade de Assunção - Paraguai proporcionaram a obtenção de rendimentos oito vezes maiores em cultivos irrigados, quando comparados aos sistemas convencionais de produção (sem o uso desta técnica). A produção variou de $250 \mathrm{~kg} \mathrm{ha}^{-1}$ à $2.000 \mathrm{~kg} \cdot \mathrm{ha}^{-1}$ para uma única colheita (González, 2000). O autor também cita que o déficit hídrico pode reduzir até $80 \%$ da massa foliar, principalmente, no momento do transplante e pega, período em que a cultura é altamente exigente em disponibilidade hídrica.

Utumi (1994) estudou, em Viçosa-MG, os componentes do rendimento da cultura da estévia, submetida à deficiência nutricional de 6 macroelementos individualmente e um tratamento testemunha. O experimento foi conduzido com iluminação artificial em sistema hidropônico. A autora encontrou produtividade de 27,14 g.planta ${ }^{-1}$. Tal produtividade é considerada boa, pois tratava-se do primeiro corte. Considerando-se 66.666 plantas por hectare, corresponderia a $1.800 \mathrm{~kg} \cdot \mathrm{ha}^{-1}$.

Ao passo que Lima Filho (1995), também estudando deficiências nutricionais, encontrou uma produção de 8 gramas folhas por planta nos melhores tratamentos. Este valor é muito baixo, comparado aos encontrados em campos de cultivos, mesmo quando para uma primeira safra (Bertonha, 2000). Os valores de índice de área foliar foram de $0,35,10 \%$ dos valores encontrados em campos comerciais.

\subsection{Determinação da evapotranspiração}

O conhecimento da dinâmica do consumo de água de uma cultura ao longo do seu ciclo de crescimento e desenvolvimento é fundamental para o manejo racional e eficiente da água em sistemas de irrigação. Os sistemas 
agrícolas são essencialmente ineficientes na utilização dos recursos hídricos, haja visto que as culturas consomem por evapotranspiração, durante o ciclo vegetativo, em média, 400 a $800 \mathrm{Kg}$ de água para produzir $1,0 \mathrm{~kg}$ de matéria seca (Voltolini \& Silva, 1995). Afinal, a maioria das plantas agrícolas retém uma quantidade de água insignificante quando comparada com a evapotranspiração total das plantas. Observa-se, ademais, que somente cerca de $1 \%$ da água absorvida pela planta é consumida nas atividades metabólicas (Rosenberg, 1974). Aliada à baixa eficiência ainda constata-se a falta de um manejo racional da água, com base nas características edafoclimáticas e fenológicas das culturas irrigadas.

Mesmo em cultivos de sequeiro, o conhecimento das necessidades hídricas de uma cultura permite o melhor aproveitamento das disponibilidades hídricas de cada região. Por exemplo, períodos de maior exigência de água disponivel para as diferentes espécies, tais como, florescimento, semeadura (períodos críticos), podem e devem coincidir com períodos de maior incidência de chuvas e/ou disponibilidade de água no solo. Atrelado a isso, é possível efetuar programas de regionalização das cultivares, que propiciem a potencialização de rendimento (Doorenbos \& Kassam, 1979; Matzenauer,1999).

Cabe ressaltar que a água exerce papel fundamental no desenvolvimento de uma cultura, afetando principalmente o crescimento do sistema radicular e a absorção e transporte de nutrientes na planta. A medida que a planta for se desenvolvendo, aumenta a quantidade de água que ela necessita. No pleno desenvolvimento, requer, para satisfazer suas exigências, o máximo de suprimento. Isso evidencia a importância de se quantificar o consumo de água das diversas espécies ou cultivares em cada região e nas diferentes épocas do ano. Afinal, a água é um dos fatores imprescindíveis para se obter aumentos no rendimento das culturas (Martin de Santa Olalla \& De Juan Valero, 1993; Bernardo, 1995).

A quantidade de água extraída pelos vegetais depende de algumas propriedades da cultura, tais como a densidade e sua profundidade do sistema 
radicular e sua capacidade fisiológica de extração da água do solo que impede a murcha da planta. Ainda, depende das propriedades do solo (como: condutividade hidráulica, difusividade, sucção e teor de água no solo) e das condições climáticas que interferem na transpiração da cultura (Azevedo, 1993).

Para a determinação do consumo de água de uma cultura, a água do solo deve estar prontamente disponível, isto é, as condições de solo devem ser tais que o fluxo de água atenda qualquer demanda atmosférica (Winter, 1986; Folegatti, 1988; Reichardt, 1996; Pereira et al., 1997). A quantidade de água disponível depende da habilidade das raízes em absorver a água do solo com que estão em contato, bem como das propriedades do solo no fornecimento e na condução desta água até as raízes em uma proporção que satisfaça as exigências da transpiração. Uma das maneiras mais utilizadas de quantificação do consumo de água é através da medida da evapotranspiração.

A evapotranspiração é o processo simultâneo de evaporação de água no solo e de transpiração das plantas. Rosenberg (1974) define evaporação como "o processo físico pelo qual um líquido ou sólido passa para o estado gasoso" e a transpiração "o processo de evaporação da água que passa pela planta, entrando pelas raízes, passando pelos tecidos vasculares até as folhas ou outros órgãos e saindo para a atmosfera, pelos estômatos ou superfície das cutículas".

Klar (1984) considera a transpiração como processo fundamental para as plantas, pois age como solvente e agente transportador de nutrientes pelo floema e xilema, participa das atividades metabólicas, promove o resfriamento dos tecidos vegetais e mantém a turgescência das células.

Segundo trabalho de Klocke et al. (1990), ocorre diferenças entre a evaporação e a transpiração, no total do processo evapotranspirativo, ao longo do desenvolvimento de uma cultura, em função do índice de área foliar (IAF) e do tipo de cobertura do solo. Quando a umidade do solo é elevada, constatouse alta taxa de evaporação comparada à transpiração. Quando os solos estão com baixos níveis de umidade, essa situação inverte-se. Quando o IAF é baixo, 
prevalece a evaporação, sendo responsável por cerca $80 \%$ da água evapotranspirada até $10 \%$ da cobertura do solo. Relata-se também que, quando a evaporação diminui e o IAF é alto, não se reduz a evapotranspiração, pois a transpiração aumenta.

Segundo Matzenauer (1999), a determinação da evapotranspiração máxima das culturas agrícolas, sem limitação hídrica, é a de maior importância e interesse nas pesquisas agronômicas. A evapotranspiração depende da demanda evaporativa da atmosfera, determinada por quatro componentes climáticos: radiação solar, vento, umidade e temperatura do ar. Destes, a radiação solar é o elemento de maior importância na demanda evaporativa da atmosfera, consequentemente na evapotranspiração. A evapotranspiração é diretamente dependente da disponibilidade de energia e de água no solo. $A$ energia é suprida pela radiação solar, somado a energia advectiva, já a água, é fornecida pela irrigação ou pelas chuvas.

Para Scaloppi (1972), a intensidade de evapotranspiração é dependente do regime de umidade no solo, estágio de crescimento das plantas e das condições climáticas.

A evapotranspiração potencial (ETp) foi definida por Penman (1956) como sendo o processo de transferência de água para a atmosfera, por unidade de tempo, de uma superfície totalmente coberta por uma vegetação rasteira, em pleno desenvolvimento vegetativo e sem restrições hídricas.

Ao passo que Doorenbos \& Pruitt (1977) definiram a evapotranspiração potencial da cultura (ETc) como aquela que ocorre em uma cultura livre de doenças, desenvolvendo-se sob condições ótimas de solo, incluindo água e fertilidade. A ETc refere-se à demanda climática ideal de água, que se consegue mantendo o solo próximo a sua capacidade de campo. Cabe observar que os conceitos de ETp, ETm e ETc são similares em condições ideais de cultivo (umidade do solo, nutrição mineral, sanidade).

Sentelhas (2001) cita que os fatores que afetam a evapotranspiração são classificados em: a) fatores climáticos, b) da planta e c) de manejo e do 
solo. Como fatores climáticos, exercem papel importante: o saldo de radiação, a temperatura do ar, a umidade relativa e a velocidade do vento. As variações na evapotranspiração dependentes da planta são: espécie, coeficiente de reflexão, área foliar, altura da planta e profundidade do sistema radicular. Por último, os fatores de manejo e do solo são: espaçamento e densidade de plantio, tipo de solo, disponibilidade de água no solo, plantio direto/cobertura do solo e impedimentos físico-químicos.

Para Burman et al. (1980), a determinação da evapotranspiração pode ser dividida em duas formas: 1) por meio de medidas indiretas, que utilizam equações empíricas, semi-empíricas e evaporímetros e 2) com medidas diretas, feitas com lisímetros, e pelo balanço hídrico de campo, que usa um determinado volume de solo. O balanço hídrico é a contabilização da variação do armazenamento de água no solo, como resultante do balanço entre as entradas e saídas de água. Trata-se de uma técnica limitada em função da variabilidade espacial das características físicas do solo e das dificuldades de obtenção de algumas medidas, como a drenagem profunda. Devido a estes fatores, utiliza-se com maior intensidade os lisímetros.

\subsection{Evapotranspiração de referência e coeficiente de cultura}

No planejamento e manejo de projetos de irrigação, geralmente, as tomadas de decisões são efetuadas a partir de parâmetros agrícolas. Um desses, é o coeficiente de cultura, que é influenciado pelos diferentes estádios das culturas. Os estádios, ou fases, variam de acordo com as condições ambientais e da própria cultura em questão (Doorenbos e Pruitt, 1984). Estes autores dividem os ciclos dos cultivos em quatro fases distintas: inicial, crescimento rápido, média e final. É importante ressaltar que esta divisão está condicionada ao cultivo de espécies produtoras de grãos. Para culturas onde o objetivo é a produção de massa seca de folhas, normalmente o ciclo é dividido em 3 fases até a floração, que é o ponto de corte. Como exemplo é possivel 
citar as plantas para produção de feno, chás, ou mesmo a estévia.

Doorenbos \& Pruitt (1977) definiram a evapotranspiração potencial de referência (ETo) como sendo a que ocorre em uma superfície totalmente vegetada com grama, com 8 a $15 \mathrm{~cm}$ de altura, em fase de crescimento ativo, estando o solo com uma umidade próxima àquela da capacidade de campo. $A$ razão entre ETc e ETo denomina-se coeficiente de cultura $(\mathrm{Kc})$. Os fatores que o afetam são: as características próprias da cultura, a duração do ciclo vegetativo e as condições climáticas locais (Burman et al., 1983; Saad e Scaloppi, 1988). Vários são os métodos para determinação de ETo, entre os quais podem ser citados: Penman, da Radiação, Blaney-Criddle e do Tanque Classe A.

Villa Nova \& Reichardt (1989) classificaram como métodos mais recomendados para estimativa da evapotranspiração de referência (ETo), para as condições brasileiras de solo e clima: Penman, Thornthwaite, radiação solar e tanque classe $A$.

Segundo Pereira et al. (1999), os coeficientes de cultura têm um papel prático essencial na determinação da evapotranspiração. Fazem esta conclusão considerando que, na atualidade, as informações existentes sobre a resistência aerodinâmica do dossel e a resistência superficial da planta são insuficientes para calcular diretamente a evapotranspiração da cultura. $O$ autor afirma que apesar dos coeficientes da cultura $(\mathrm{Kc})$ serem considerados empíricos, bases teóricas justificam seu uso. Portanto, o cálculo de ETc (Kc $\times$ ETo) pode ser compatível com a estimativa direta de ETc usando-se a equação de PenmanMonteith.

Neste sentido, Smith (1991) considerou este método como o de melhor desempenho entre os métodos combinados, recomendando como método-padrão para a obtenção de ETo. O mesmo resultado foi encontrado por Peres et al. (1995), avaliando o modelo de Penman-Monteith para estimativa da evapotranspiração padronizada pela FAO em três localidades do Estado de São Paulo. Foram encontrados dados de estimativa da ETo consistentes, 
comparados ao lisímetro de drenagem-padrão, tanto na escala decendial como na mensal. Em contraposição a esses autores, Camargo \& Sentelhas (1997) observaram uma superestimativa da ETo para dados mensais do Estado de São Paulo, quando utilizaram o Método Penman-Monteith.

A determinação do coeficiente de cultura $(\mathrm{Kc})$ permite o manejo da irrigação através de equipamentos simples e de fácil execução como o tanque classe $A$, equipamento de fácil manejo para o produtor. $O$ valor deste coeficiente é afetado, principalmente, pelas características da cultura, estádio de desenvolvimento, extensão do ciclo da cultura e condições climáticas (Villa Nova \& Sentelhas, 1999; Peres et al., 1992).

Doorenbos \& Pruitt (1977) citam que as condições e práticas agrícolas locais, inclusive os tipos de plantas e a seleção de variedades, também podem interferir consideravelmente na evapotranspiração da cultura (ETc) e, consequentemente, exigir certas correções. O coeficiente de cultura varia muito dentro de uma espécie, em função de suas variedades com diferentes características fenológicas, profundidade e densidade do sistema radicular, ciclo e capacidade evaporativa da atmosfera. Quando o solo está totalmente coberto, esse coeficiente varia pouco entre as fases. Porém, nas duas fases iniciais, depende, principalmente, do conteúdo de água na camada superficial do solo, pois a evaporação é a principal representante da evapotranspiração da cultura (Mantovani, 1993; Pereira \& Allen, 1997).

Soares (1999) estudando coeficientes de cultura no estádio inicial para diferentes texturas de solos e condições de molhamento encontrou maior valor de Kc para solo de textura fina, quando comparado ao solo de textura grossa, sob mesmas condições climáticas e de molhamento. Para o solo com textura fina, o aumento do Kc foi da ordem de $150 \%$ quando a lâmina aplicada foi de $40 \mathrm{~mm}$ a cada 10 dias, comparada à lâmina de $5 \mathrm{~mm}$. Variou de 0,4 para 1,0 quando houve maior disponibilidade hídrica. A ETc variou de 1,2 para 3 mm.dia ${ }^{-1}$, e a ETo, pelo médodo Penman-Monteith, foi de $3 \mathrm{~mm} \cdot \mathrm{dia}^{-1}$. O autor cita que a umidade do solo tem grande interferência no período inicial de 
cultivo, devido a pouca cobertura do solo, prevalecendo o fenômeno da evaporação no processo evapotranspirativo.

Também encontraram resposta semelhante Jagtap \& Jones (1989), estudando a estabilidade dos coeficientes culturais sob diferentes climas e condições de umidade do solo. Esses autores constataram que a diferença dos Kc tende a desaparecer quando a cultura atinge $30 \%$ a $40 \%$ do seu desenvolvimento.

Lourenço et al. (2001) determinaram o Kc do capim tanzânia para duas fases da cultura. A ETc foi calculada a partir da variação da umidade do solo medida através de tensiômetros. Já para encontrarem os valores de ETo, utilizaram os métodos de Penman-Monteith e do tanque classe A. Os valores de Kc foram 0,50 e 0,45 na fase inicial e 0,98 e 0,93 durante o período que antecedia o pastejo, respectivamente. Ou seja, os valores de ETo determinados pelo método Penman-Monteith foram, inferiores aos estimados pelo tanque.

Allen et al. (1998) sugeriram que os valores de coeficiente de cultura (Kc) sejam determinados empiricamente para cada cultura baseados em dados de lisímetro e nas condições climáticas locais. Coeficientes de cultura sugeridos por pesquisadores têm sido utilizados para inúmeras culturas sob as mais diversas condições climáticas. Contudo, muitas vezes, esses coeficientes não têm revelado as verdadeiras condições da evapotranspiração da cultura para um determinado local e uma cultura específica de maneira satisfatória.

Para a determinação da evapotranspiração de referência, vários autores citam que o método Penman-Monteith - FAO tem demonstrado ser um dos mais eficientes (Pereira, 1998). Smith et al. (1996) estudaram a aplicação de 20 métodos de estimativa de ETo. Foram aplicados métodos combinados de radiação, de temperatura e do tanque de evaporação para regiões áridas e úmidas. Em ambas regiões, o método Penman-Monteith, comparado aos lisímetros, foi o que apresentou a melhor estimativa, com menor variação porcentual e desvio padrão nos dados. Constatou-se uma superestimativa de $4 \%$ para as regiões úmidas e uma subestimativa de $1 \%$ para regiões áridas. 


\subsection{Lisímetros}

Bernardo (1995) classifica os métodos para determinação da evapotranspiração em dois grandes grupos: métodos indiretos e métodos diretos. Os indiretos são divididos em evaporimétricos e os que empregam equações. Os diretos, representados pelos lisímetros, pelas parcelas experimentais no campo, pelo controle da umidade no solo e pelo método da entrada e saída em grandes áreas.

Os lisímetros ou evapotranspirômetros se destacam por permitirem a obtenção da evapotranspiração real da cultura no nível de campo. São definidos como recipientes de grande volume, cheios de solo, com superfície nua ou coberta, representando as condições ambientais dos campos onde estão instalados (Aboukhaled et al., 1982).

Existem diferentes tipos de lisímetros usados em pesquisas com a finalidade de obter a evapotranspiração de uma espécie agrícola, porém, a maioria apresenta elevado custo de instalação ou fornece os resultados com um certo atraso, de um dia ou mais. Geralmente, possuem sofisticações que dificultam a sua instalação em implantes comerciais, por exigirem um elevado nível de conhecimento do agricultor.

O uso de lisímetros, visando determinar a evapotranspiração de uma cultura em desenvolvimento, ocorreu na década de 50 nos Estados Unidos (Pruitt \& Jensen, 1955). Nas duas décadas posteriores, com o crescente uso da tecnologia computacional e eletrônica, estes equipamentos também foram empregados em estudos meteorológicos, com leituras para períodos menores que um dia (Black et al. 1968; Pruitt et al. 1972).

Segundo Sediyama (1995), a principal limitação apresentada pelos lisímetros é que dificilmente as condições internas destes são semelhantes às condições externas de cultivo. Nesse sentido, Azevedo (1999) afirma que as principais imperfeições de medidas de ETc são causadas pelas condições artificiais do solo, descontinuidade entre a vegetação do lisímetro e da área de 
cultivo ou circundante, a pequena dimensão dos lisímetros e a variação da disponibilidade hídrica entre o lisímetro e a área de cultivo.

Os lisímetros devem ser instalados de modo que representem o mais próximo possível as condições naturais do solo e da vegetação. Devendo, portanto, evitar obstáculos que possam interferir na radiação natural ou nos movimentos atmosféricos. Também é importante manter uma área tampão suficientemente grande, visando evitar problemas de advecção (Pruitt \& Angus, 1960; van Bavel, 1961; Ritchie \& Burnett, 1968; Amorim, 1998).

Lunardi (2000) cita que, basicamente, são dois os tipos de lisímetros: os de pesagem e os de não-pesagem. Os de pesagem contabilizam a variação de armazenamento de água no solo, de forma mecânica, eletrônica, hidráulica ou flutuante. Este tipo apresenta dificuldades para medir e registrar com exatidão pequenas variações de peso em relação a grande massa e volume de solo. São indicados para estudos onde se necessita medir a evapotranspiração em curtos intervalos de tempo. Suas limitações são alto custo, dificuldade de construção, instalação e manutenção, exigindo mão-de-obra especializada (Aboukhaled et al., 1982). No entanto, são considerados os mais precisos na medida da evapotranspiração e são os mais recomendados pelos pesquisadores (Allen et al., 1989; Pruitt, 1991; Allen et al. 1991).

Por outro lado, os lisímetros de não-pesagem podem ser de drenagem ou de compensação com lençol freático constante a uma determinada profundidade. Nos de drenagem, o excesso de água é coletado volumetricamente, sendo a evapotranspiração igual à diferença entre a água aplicada e a drenada. Pode-se também determinar o armazenamento obtendo a variação da umidade (recorrendo-se a: tensiômetros, sonda de neutrons, resistência elétrica e amostragem do solo). Os lisímetros de drenagem tem como limitação a demora na percolação em solos pesados e a necessidade de irrigações freqüentes para manter o solo na capacidade de campo. Tais características exigem que sua utilização seja para períodos maiores que uma semana (Aboukhaled et al., 1982). 


\subsection{Microlisímetro de lençol freático constante}

Os lisímetros de lençol freático constante tem como princípio um lençol freático mantido a uma determinada profundidade. A água é translocada até a zona radicular por capilaridade, causando uma diminuição no nível, que é compensado por um mecanismo flutuador. É possível citar alguns autores que utilizaram esse tipo de equipamento: Encarnação (1980), Barbieri (1981), Azevedo et al. (1987), Cury \& Villa Nova (1987), Encarnação et. al. (1987), Santos et al. (1988) e Megale \& Bertolacci (1999). Utilizando o lisímetro de lençol freático de nível constante na determinação da evapotranspiração de culturas como: feijoeiro, cana-de-açúcar, tomate e batatinha; todos os autores têm dado preferência a esse método, em detrimento ao de drenagem, pela sua simplicidade e maior automação.

Becker (1990), estudando o consumo hídrico de duas cultivares de alface, usando lisímetros de lençol freático constante e comparando com os principais elementos do clima, encontrou boa correlação entre os valores de evapotranspiração medidos pelo lisímetro e a temperatura do ar. $\mathrm{O}$ autor ressalta a importância do controle da entrada de água nos lisímetros, que possa ocorrer por ocasião das precipitações.

Já, Moura et al. (1993) encontraram alta precisão nos dados de evapotranspiração utilizando 3 lisímetros de lençol freático constante para determinar o consumo de água na cultura da cenoura e destacam o método também pela facilidade operacional. Além disso, comparando os valores de coeficiente da cultura com os propostos pela FAO, encontraram certa variabilidade nos valores, o que demonstra a necessidade de determinação de Kc específico para uma dada região de estudo.

Por sua vez, Assis (1978) estudando métodos de medida e estimativas da evapotranspiração, concluiu que o evapotranspirômetro de nível de água constante, com um sistema de registro diário acoplado, pode ser utilizado em estudos de evapotranspiração em escala diária. Porém, segundo 
Allen et al. (1991), este tipo lisímetro foi estudado por vários pesquisadores e as determinações são mais precisas para períodos maiores que 3-5 dias. Os autores recomendam, que quando se deseja alta precisão e medições horárias ou em menores espaços de tempo, é recomendável utilizar os lisímetros de pesagem.

Em trabalho realizado por Sarraf ${ }^{1}$, citado por Lunardi (2000), que visava comparar lisímetros de nível freático constante de $4 \mathrm{~m}^{2}$ com grandes lisímetros de pesagem, encontrou-se diferenças de apenas 1 a $2 \%$. $O$ autor cita que para a melhor precisão nas medidas, é necessário ter uma bordadura com área 10 vezes superior à área do lisímetro.

O lisímetro de nível freático apresenta como vantagem o baixo custo de instalação e manutenção, a possibilidade de ser construído com diversos tipos de materiais e, principalmente, o de atender a um dos pré-requisitos para a obtenção da evapotranspiração máxima, que é a ausência de estresse hídrico.

A característica divergente dos lisímetros de lençol freático constante em relação às condições naturais refere-se à disponibilidade de água por ascensão capilar. Sabe-se que estes movimentos da água no solo, sofrem a ação da histerese (Lunardi, 2000; Bertolacci \& Megali,1991, Reichard, 1996; Libardi, 1995). Quando se fornece água por infiltração, a distribuição da água ocorre de forma descendente, tendo auxílio do potencial gravitacional. Por outro lado, quando a distribuição (e redistribuição) da água ocorre por ascenção capilar e evaporação, o potencial gravitacional age de forma adversa, dificultando a ascensão, havendo portanto pequena diferença na curva de retenção de água.

Willianson \& Kriz (1970) afirmam que solos de textura grossa exigem nível freático mais próximo da superfície do solo que os de textura fina, onde as forças capilares são mais intensas.

\footnotetext{
${ }^{1}$ SARRAF, S. Estimation de l'ETP et consommation en eau des cultures en région semi-arid (Liban). Montpellier, 1973. 114p. Thèse (Docteur) - Faculté des Science de l'Université de Montepellier.
} 
Quando o solo estiver saturado ou com lençol freático próximo à superfície, a evaporação da água aproxima-se da evaporação de um recipiente, contendo água com a superfície livre, exposta às mesmas condições atmosféricas. Confirmando isto, Israelsen e Hansen (1967) compararam a evaporação de um recipiente que continha água com a evaporação de um solo areno-argiloso mantendo o lençol freático a várias profundidades. Os autores chegaram a conclusão de que a evaporação no tanque com solo passou de $7,2 \%$ para $88,2 \%$ da evaporação do recipiente com água, quando o lençol freático foi aumentado de $1,25 \mathrm{~m}$ para $0,10 \mathrm{~m}$ de profundidade.

Aboukhaled et al. (1982) mencionam que este tipo de lisímetro pode subestimar a evapotranspiração em locais de alta condição de evaporação, devido ao retardo na compensação hídrica pelo movimento de ascensão capilar. Neste caso, é recomendável efetuar uma irrigação auxiliar na superfície para manter a boa disponibilidade de água. Por outro lado, os autores afirmam que, quando o nível de água estiver muito próximo da superfície, em solos de alta capilaridade, constata-se a superestimação dos resultados de evapotranspiração.

No ano de 1986, o Laboratório Nacional de Irrigação (LNI), da Universidade de Pisa, iniciou os trabalhos de elaboração de um microlisímetro de ascensão capilar, de baixo custo e fácil manejo, para ser instalado em cultivos comerciais. O mesmo vem sendo aprimorado e sempre apresentou resultados satisfatórios de estimativa da evapotranspiração real nas culturas em que foi testado. Em trabalho realizado por Tozzi (1995), o microlisímetro de lençol freático constante foi eficiente como técnica para a tomada de decisão referente ao momento e quantidade de água de irrigação. Utilizando o mesmo equipamento, Megale \& Betolacci (1999) estudaram a resposta da cultura do melão a diferentes lâminas de irrigação baseadas em medidas do lisímetro de lençol freático constante. Durante o primeiro ano, utilizaram como intervalo $20 \%$ de dose da irrigação $(60 \%, 80 \%, 100 \%, 120 \%$ e $140 \%)$ e nos dois anos seguintes, $10 \%$ (70\%, 80\%, 90\%, 100\%, 110\%, 120\%). A variação na produção 
não foi significativa nas dosagens entre $80 \%$ e 100\%). Os resultados foram obtidos em 3 anos de cultivo (1996 a 1998). Respostas idênticas foram encontradas para as culturas do tomateiro e pimentão, ou seja, a melhor rentabilidade foi obtida quando a irrigação foi semelhante à evapotranspiração medida. Valores de irrigação superiores à ETP não apresentaram ganhos de rendimento estatisticamente diferentes, somente ocasionaram gastos de água e bombeamento. Para culturas de baixo valor comercial, pesquisas desenvolvidas na região da Toscana - Itália, indicam a utilização de somente $80 \%$ da ETP medida, devido à baixa diferença em produtividade com maiores lâminas de água.

Fontes (1996) afirma que a altura ideal do lençol freático varia com a cultura e o tipo de solo. O mesmo autor constata que os valores de evapotranspiração foram superestimados em $20 \%$, para o couve brócolo, em uma profundidade de $40 \mathrm{~cm}$, quando comparados aos valores de evapotranspiração com o lençol freático a $50 \mathrm{~cm}$. A sensibilidade aos fatores climáticos foi maior na menor altura do lençol freático. A mesma tendência encontrou Valadão (1995) com a cultura do feijão, ou seja, quando o lençol freático esteve a $50 \mathrm{~cm}$, a evapotranspiração foi $55 \%$ maior que a $75 \mathrm{~cm}$ de profundidade.

Estudando $\mathrm{o}$ efeito de quatro profundidades freáticas sobre 0 consumo hídrico da alface, Reis (1991) observou que o consumo foi maior na menor profundidade freática de $25 \mathrm{~cm}$, decrescendo com o aumento da profundidade. A evapotranspiração foi equivalente ao tanque de evaporação classe $A$, quando o lençol freático esteve nas profundidades de $35 \mathrm{~cm}$ a $45 \mathrm{~cm}$. Trabalho semelhante elaborado por Andrade (1991) com milho-doce concluiu que a evapotranspiração foi maior quando o lençol freático esteve a $30 \mathrm{~cm}$, também reduzindo com o rebaixamento do nível freático. Porém, em todas as profundidades estudadas, a evapotranspiração foi maior que a evaporação do tanque classe $\mathrm{A}$.

Pereira (1994) estudando lisímetros de lençol freático constante, 
verificou que a evapotranspiração na cultura da alface, foi maior quando o lençol freático esteve a $25 \mathrm{~cm}$, comparado às profundidades de $35 \mathrm{~cm}, 45 \mathrm{~cm}$ e $55 \mathrm{~cm}$. No entanto, a evaporação do tanque classe $A$ foi maior que a dos tratamentos nos diferentes lisímetros. Os coeficientes de cultura também diminuíram conforme a profundidade do lençol freático. A maior produção foi obtida quando o lençol freático esteve mais próximo à superfície, a $25 \mathrm{~cm}$, e a produção por milímetro de água evapotranspirada foi semelhante nas profundidades de 25 e $35 \mathrm{~cm}$.

Pesquisa realizada por Carter \& Floyd (1977), estudando os efeitos da altura do lençol freático sobre a produtividade da cana-de-açúcar plantada em solo franco-argiloso, submeteu tratamentos de $30 \mathrm{~cm}, 76 \mathrm{~cm}$ e $122 \mathrm{~cm}$ de profundidade. Os autores relataram que a produtividade média dos tratamentos $30 \mathrm{~cm}$ e $76 \mathrm{~cm}$ foi $60 \%$ menor que o de $122 \mathrm{~cm}$ para a $2^{\text {a }}$ soca e, para a $3^{\text {a }}$ soca, os tratamentos 30 e $76 \mathrm{~cm}$ tiveram produções de $54 \%$ e $22 \%$ menores que o de $122 \mathrm{~cm}$, respectivamente, afetando o número e o peso de colmos.

Já, Sousa (1992) estudou o consumo hídrico do algodoeiro medido por lisímetros de lençol freático constante, sob três profundidades: $25 \mathrm{~cm}, 50$ $\mathrm{cm}$ e $75 \mathrm{~cm}$. Nesse caso, encontrou-se uma superestimação da evapotranspiração quando o lençol freático esteve a $25 \mathrm{~cm}$. Mas, na ocasião em que a cultura atingiu pleno desenvolvimento, os resultados passaram a ser semelhantes para as três profundidades estudadas. $O$ autor ainda cita que o desenvolvimento do algodoeiro foi melhor quando o lençol esteve a $75 \mathrm{~cm}$ de profundidade, por causa da exigência da cultura de bons níveis de aeração do solo. Ademais, ressalta-se a importância da existência de cobertura móvel para evitar a perda de leituras em dias de alta pluviosidade. 


\section{MATERIAL E MÉTODOS}

\subsection{Caracterização da área experimental}

A pesquisa foi conduzida na área experimental do Departamento de Agronomia e Gestão do Agroecosistema da Universidade de Pisa, em San Piero a Grado - Pisa, Província da Toscana, Região centro-oeste da Itália (Figura 1). O local é situado a $43^{\circ}$ de latitude Norte e $11^{\circ}$ de longitude Leste de Greenwich, com altitude de $5 \mathrm{~m}$.

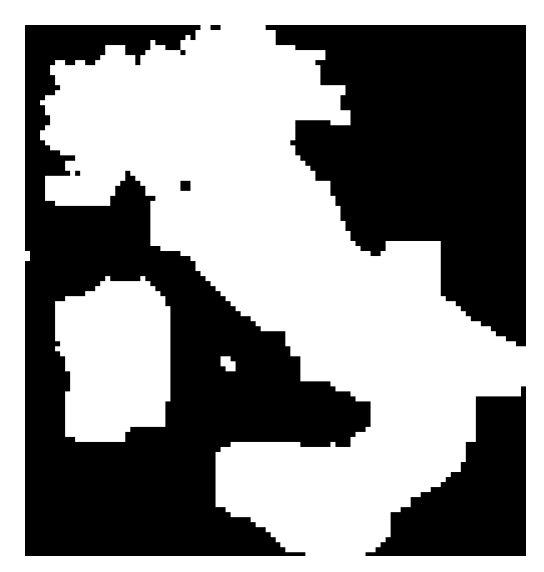

Figura 1 - Localização da cidade de Pisa, Província da Toscana - Itália.

O clima predominante na região é do tipo mediterrâneo costeiro, com chuva bem distribuída no outono e primavera local. As precipitações são poucas ou nulas durante os períodos de verão e inverno. As temperaturas durante o verão variam de $20^{\circ} \mathrm{C}$ a $30^{\circ} \mathrm{C}$ com poucos dias superando os $35^{\circ} \mathrm{C}$. $\mathrm{O}$ solo da área experimental é classificado como franco, com $51 \%$ de areia, 39\% 
de silte e $10 \%$ de argila.

A área experimental está localizada a $3 \mathrm{~km}$ do Mar Mediterrâneo e 12 $\mathrm{km}$ do centro de Pisa. Nesta área é realizado grande parte das pesquisas agrícolas da referida Universidade.

Ao redor do experimento, toda superfície permaneceu vegetada, sendo que havia gramado e alfafa na margem leste e outro experimento com estévia na margem oeste. Na face norte, havia vegetação baixa em um raio de $100 \mathrm{~m}$ e, na face sul, casas de vegetação instaladas a $40 \mathrm{~m}$ do experimento. Esta descrição é pertinente, pois, tratando-se de uma pesquisa envolvendo evapotranspiração, não deve haver barreiras, naturais ou artificiais, de forma que haja passagem natural dos ventos e raios solares durante todo o período experimental.

No início da execução dos trabalhos, em maio de 2000, foram coletadas amostras de solo, peneiradas e elaborada a curva característica de retenção de água no solo (umidade versus potencial mátrico), utilizando uma câmara de pressão com placa de Richards, sob condições de laboratório, conforme descrito por Libardi (1995), no Laboratório Nacional de Irrigação.

$\mathrm{Na}$ curva de retenção de água no solo (Figura 2), observa-se que os pontos de 0,5 e $1 \mathrm{MPa}$ não foram determinados devido a danos na câmara de determinação.

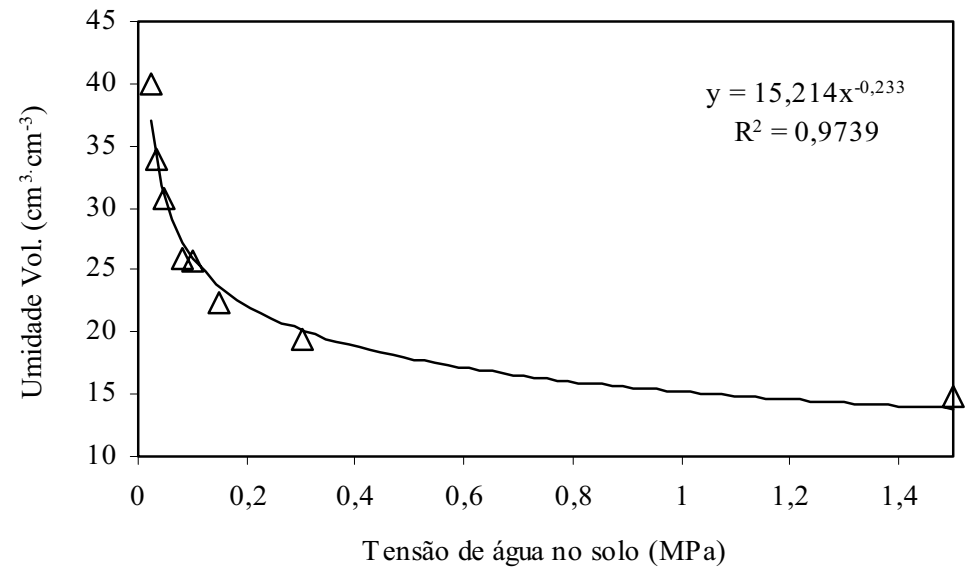

Figura 2 - Curva de retenção de água no solo da área experimental. 
A análise granulométrica do solo está apresentada na Tabela 1. Notase que são solos com grande quantidade de silte (39\%), os quais exigem cuidados em seu manejo quanto à infiltração de água no solo e/ou facilidade de compactação em conseqüência das práticas culturais.

Tabela 1. Composição granulométrica e classificação textural do solo.

\begin{tabular}{cccc}
\hline Areia $(\%)$ & Silte $(\%)$ & Argila $(\%)$ & Classificação Textural \\
\hline 50,82 & 39,14 & 10,04 & Franco - arenoso \\
\hline
\end{tabular}

Nas Tabelas 2 e 3, são descritas as características químicas do solo. Trata-se de um solo com boa fertilidade, por serem formados dos sedimentos carreados das montanhas.

Tabela 2. Composição química dos nutrientes do solo da área em foi desenvolvida a pesquisa.

\begin{tabular}{lcccccc}
\hline Material & $\begin{array}{c}\text { Matéria orgânica } \\
(\%)\end{array}$ & $\mathrm{N}$ total $\left(\mathrm{g} \cdot \mathrm{kg}^{-1}\right)$ & $\mathrm{N}$ nítrico $\left(\mathrm{g} \cdot \mathrm{kg}^{-1}\right)$ & $\mathrm{P}$ Total $\left(\mathrm{mg} \cdot \mathrm{kg}^{-1}\right)$ & $\begin{array}{c}\mathrm{K} \text { trocável } \\
\left(\mathrm{mg} \cdot \mathrm{kg}^{-1}\right)\end{array}$ & $\begin{array}{c}\text { Calcário Total } \\
(\%)\end{array}$ \\
\hline Quantidade & 2,12 & 1,11 & 5,6 & 60,1 & 173,24 & 1,72 \\
\hline
\end{tabular}

Outra característica dos solos da região é a presença de calcário, que confere um $\mathrm{pH}$ elevado aos solos da região, dispensando a necessidade da calagem (Tabela 3).

Tabela 3. Análise do pH, condutividade elétrica e CTC do solo.

\begin{tabular}{lccc}
\hline Material & $\mathrm{pH}$ & Condutividade elétrica $\left(\mathrm{mS} \cdot \mathrm{m}^{-1}\right)$ & $\mathrm{CTC}\left(\mathrm{meq} \cdot \mathbf{1 0 0 g}^{-1}\right)$ \\
\hline Quantidade & 8,16 & 0,311 & 19,12 \\
\hline
\end{tabular}

$\mathrm{Na}$ Tabela 4 encontram-se os resultados de algumas análises físicohídricas da área em que se realizou o experimento. Estes solos apresentam uma capacidade de campo de $33,54 \%$, correspondente a pouco acima de 
metade da porosidade total, que é de 50,57\% $\left(\mathrm{cm}^{3} \cdot \mathrm{cm}^{-3}\right)$. A capacidade de campo foi determinada pelo método de campo, onde o solo é saturado, coberto com filme plástico até ocorrer a drenagem natural. Nesse caso, 48 horas após a saturação. Já, o ponto de murcha permanente é de 14,67\%. Este foi determinado à uma tensão de 1,5 MPa.

Tabela 4. Resultados de algumas características físico-hídricas do solo experimental.

\begin{tabular}{lcccc}
\hline Material & C.C $\left(\mathrm{cm}^{3} \cdot \mathrm{cm}^{-3}\right)$ & P.M.P. $\left(\mathrm{cm}^{3} \cdot \mathrm{cm}^{-3}\right)$ & Densidade real & Porosidade Total $\left(\%, \mathrm{~cm}^{3} \cdot \mathrm{cm}^{-3}\right)$ \\
\hline Quantidade & 33,54 & 14,67 & 1,31 & 50,57 \\
\hline
\end{tabular}

C.C. - capacidade de campo; P.M.P - ponto de murcha permanente.

\subsection{Dados Meteorológicos}

Os dados meteorológicos foram coletados na estação experimental da Universidade de Pisa, em San Piero a Grado, a 100m do local onde foi conduzido o experimento.

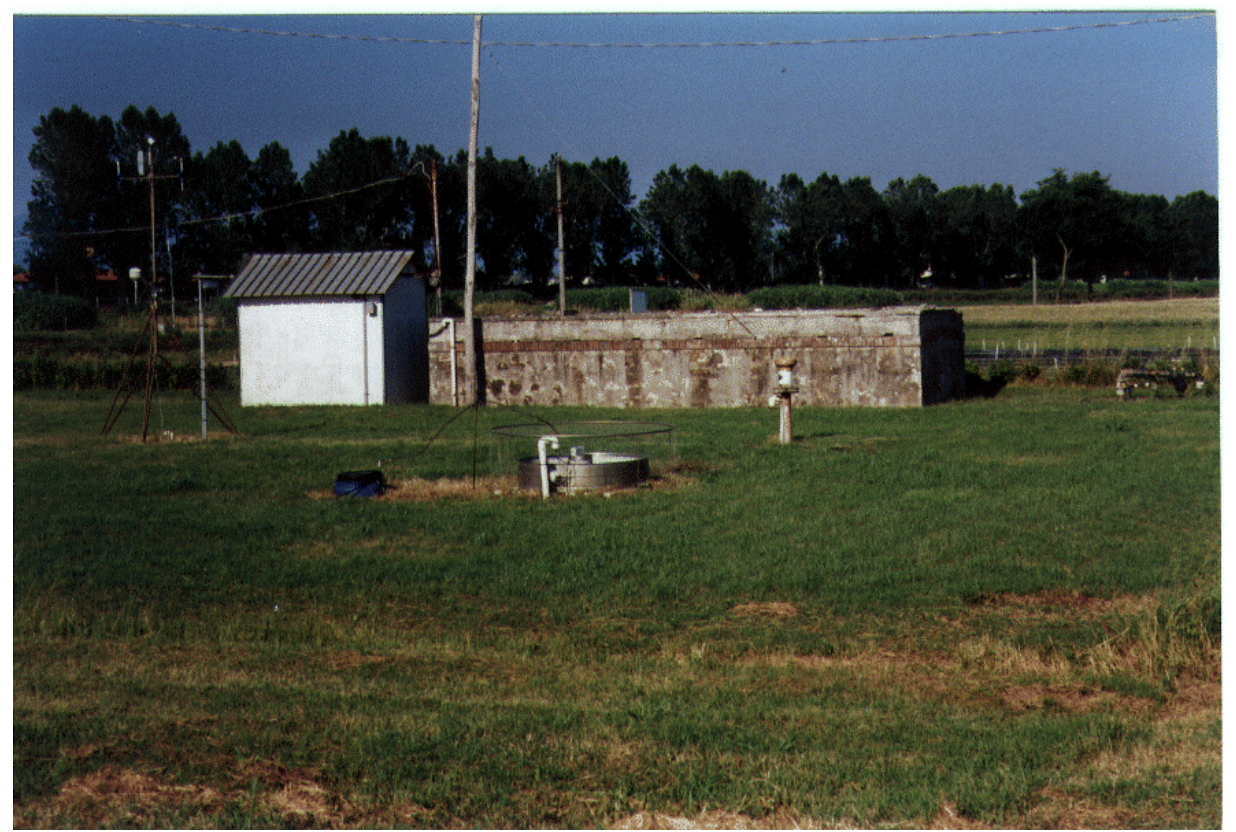

Figura 3 - Estação Meteorológica de San Piero a Grado - Pisa. 
A região litorânea (local do experimento) caracteriza-se por apresentar ventos freqüentemente contínuos durante as horas quentes do dia, características que favorecem a maior evapotranspiração das culturas agrícolas.

A duração máxima de insolação forte atinge 15,3 horas por dia durante o mês de junho e a radiação extraterrestre $(R a)$, em equivalentes de evaporação, 17,25 mm.dia ${ }^{-1}$, conforme é apresentado na Tabela 5. Apesar de que somente cerca de $50 \%$ a $60 \%$ desta energia chegue à superfície do solo, a capacidade evaporatranspirativa é elevada no verão. Este valor está próximo ao máximo para o hemisfério norte durante o mesmo período. $O$ máximo de radiação incidente ocorre na latitude $42^{\circ}$ e a área de pesquisa está localizada na latitude $43^{\circ}$. Para locais com latitude acima desse valor, não há incremento na radiação extraterrestre e sim redução da energia incidente, mesmo ocorrendo aumento da duração máxima de horas de insolação forte. Afinal, em locais de maior latitude há um aumento do ângulo de inclinação solar, ou seja, há o afastamento do trópico de câncer.

Tabela 5. Duração máxima de horas de insolação forte $(\mathrm{N})$ em diferentes meses do ano, radiação extraterrestre $(\mathrm{Ra})$ em equivalentes de evaporação $\left(\mathrm{mm} \cdot \mathrm{dia}^{-1}\right)$ e energia extraterrestre $(\mathrm{Ee})$ para a região de Pisa - Itália.

\begin{tabular}{|c|c|c|c|c|c|c|c|c|c|c|c|c|}
\hline Latitude $43^{\circ}$ Norte & Jan & Fev & Mar & Abr & Mai & Jun & Jul & Ago & Set & Out & Nov & $\overline{D e z}$ \\
\hline Horas. dia $^{-1}$ & 9,35 & 10,55 & 11,90 & 13,45 & 14,65 & 15,30 & 15,05 & 13,95 & 12,75 & 10,55 & 9,75 & 9,00 \\
\hline $\mathrm{Ra}\left(\mathrm{mm} \cdot \mathrm{dia}^{-1}\right)$ & 5,60 & 7,85 & 10,80 & 13,85 & 16,15 & 17,25 & 16,65 & 14,85 & 12,05 & 8,90 & 6,25 & 4,95 \\
\hline Ee $\left(\right.$ cal.cm ${ }^{-2} \cdot$ dia $\left.^{-1}\right)$ & 330,4 & 463,2 & 637,2 & 817,2 & 952,9 & 1018 & 982,4 & 876,2 & 651,9 & 525,1 & 368,8 & 292,1 \\
\hline
\end{tabular}

Fonte: Doorenbos \& Pruitt (1977).

\subsection{Tratamentos e delineamento experimental}

$\mathrm{O}$ experimento foi conduzido em duas partes. Na primeira parte, determinou-se o consumo hídrico da estévia medido por dois microlisímetros, ou seja, a evapotranspiração real da cultura (ETc). Posteriormente, foi estimada 
a evapotranspiração de referência (ETo) pelo método Penman-Monteith (descrito no final deste ítem). O coeficiente de cultura foi calculado dividindo-se a ETc por ETo.

$\mathrm{Na}$ segunda parte, diferentes lâminas de irrigação foram aplicadas, em 20 parcelas experimentais. As parcelas experimentais e os microlisímetros foram instalados em campo aberto.

As parcelas possuíam $15 \mathrm{~m}^{2}$ de superfície $(3 \mathrm{~m} \times 5 \mathrm{~m}), 100$ plantas em cada uma delas, espaçadas de $0,3 \times 0,5 \mathrm{~m}$, totalizando aproximadamente 67.000 plantas por hectare. $O$ delineamento experimental foi inteiramente casualizado, com 5 tratamentos e 4 repetições, totalizando 20 parcelas. Foi utilizado este delineamento estatístico devido à homogeneidade do campo experimental. As doses de irrigação aplicadas foram:

1) $100 \%$ do consumo hídrico no interior do microlisímetro (464 mm evapotranspiração da cultura da estévia, ETE);

2) $117 \%$ da ETE (538 mm);

3) $80 \%$ da ETE $(368 \mathrm{~mm})$;

4) $64 \%$ da ETE $(295 \mathrm{~mm})$;

5) sem irrigação $(70 \mathrm{~mm})$.

No tratamento 5 , sem irrigação, houve o fornecimento de água na ocasião do corte de uniformização e nas três fertirrigações. Este fornecimento de água, somado às precipitações representou $15 \%$ da ETE.

\subsection{Descrição e funcionamento do microlisímetro}

Como relatado anteriormente, o consumo hídrico da cultura foi determinado recorrendo-se ao uso de dois microlisímetros de lençol freático constante, ou também chamados de ascensão capilar. Os equipamentos estavam instalados em duas parcelas centrais do experimento, de forma que houvesse continuidade entre plantas, dentro e fora dos microlísimetros. 
Cada um dos microlisímetros possuíam $0,50 \mathrm{~m}$ de profundidade, 1,4 $\mathrm{m}$ de comprimento e 1,2 $\mathrm{m}$ de largura, totalizando uma área de $1,68 \mathrm{~m}^{2}$. No interior de cada microlisímetro, foram cultivados 10 plantas. A água foi fornecida às plantas por ascensão capilar no solo, a partir do lençol freático, conforme ilustrado na Figura 4.

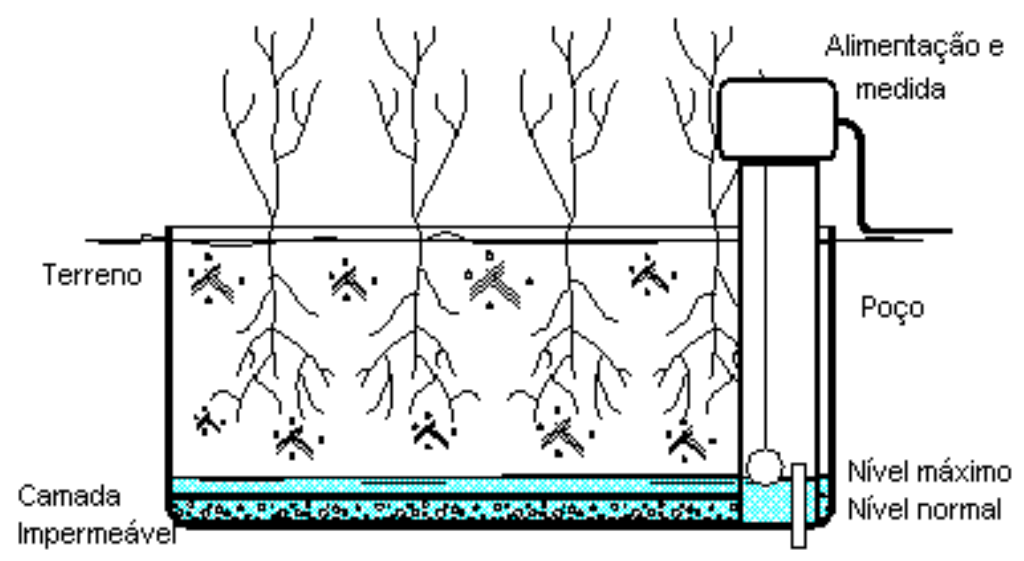

Figura 4 - Desenho ilustrativo do microlisimetro de ascensão capilar. Fonte: Laboratório Nacional de Irrigação - Universidade de Pisa.

No fundo dos microlisímetros, foi instalado uma camada de $10 \mathrm{~cm}$ de brita coberta por uma tela plástica, visando evitar o entupimento desta pelo solo. O nível da água no lisímetro foi mantido através de uma bóia flutuante, de modo que a água sempre estivesse em contato com o solo $(5 \mathrm{~cm})$. O lençol freático estava na profundidade de $35 \mathrm{~cm}$. Em função do consumo da cultura, imediatamente a água era reposta e registrada por um contador mecânico (contador de pulsos). Cada pulso representava um volume de $60 \mathrm{~cm}^{3}$. O detalhe do contador é mostrado na Figura 5.

Junto ao poço de fornecimento de água, foi instalada uma pequena bomba de 15 watts com vazão de 4 L. $\mathrm{min}^{-1}$, movida à bateria (12 volts). A bomba tinha a função de drenar o excesso ocasionado pelas chuvas, em um recipiente de volume conhecido, antes que a mesma atingisse o nível do dreno interno, no poço do microlisímetro. Na Figura 6, encontra-se a localização da microbomba e do reservatório de drenagem citados anteriormente. 


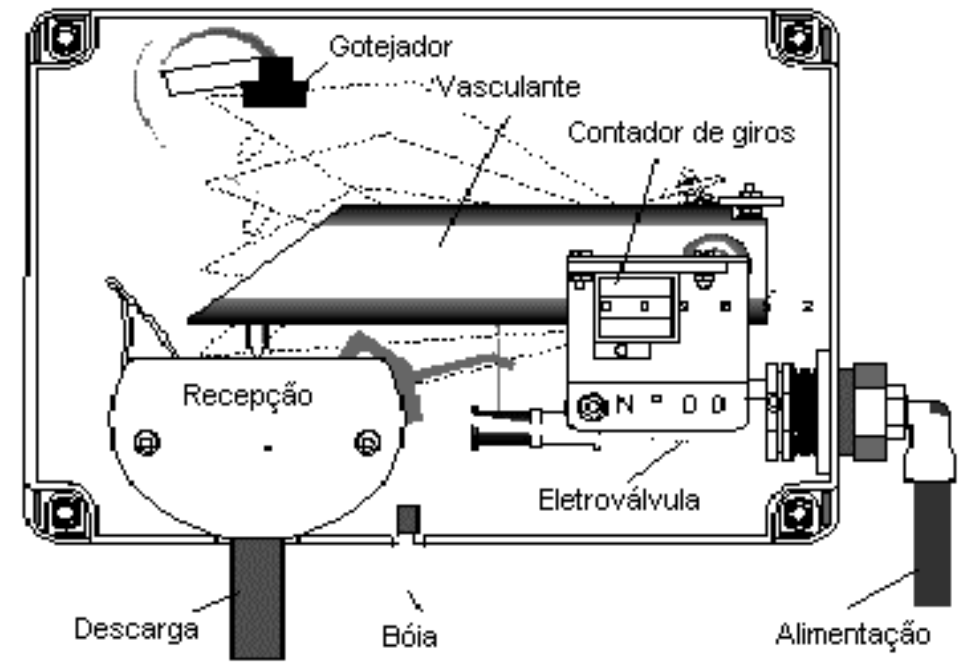

Figura 5 - Detalhe do dosador volumétrico hidromecânico de balanço e do contador de pulsos.

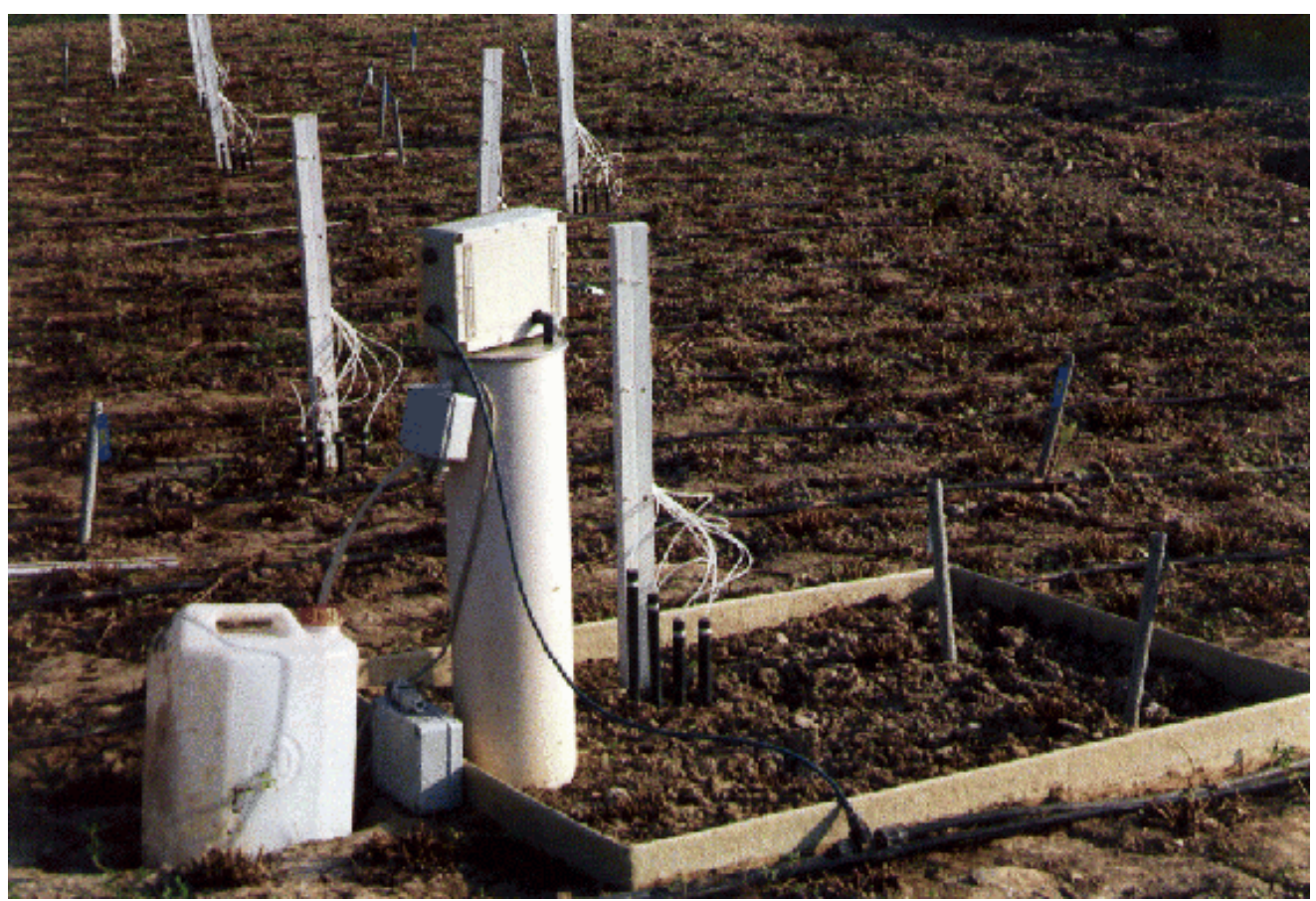

Figura 6 - Microbomba de 15 watts e reservatório utilizados para a drenagem e armazenamento do excesso de água dos microlisímetros durantes as precipitações. 
A disposição dos microlisímetros, no centro da área experimental, pode ser visualisada na Figura 7. Junto às parcelas experimentais, foi instalado um pluviômetro. Este equipamento é indispensável para que se registre a lâmina de contribuição ocasionada por eventuais chuvas. O dados de precipitação foram correlacionados com os dados de volume de água bombeada pela sistema de drenagem descrito no ítem anterior.

O microlisímetro foi desenvolvido para automatizar a coleta de dados e a irrigação através de válvulas elétricas, controladas via computador. Porém, na presente pesquisa, adotou-se a prática da verificação visual das leituras do volume evapotranspirado e escolha do momento das irrigações. Adotou-se esta opção em função de ter que aplicar volumes considerados de tal forma que atingisse a maior parte do sistema radicular.

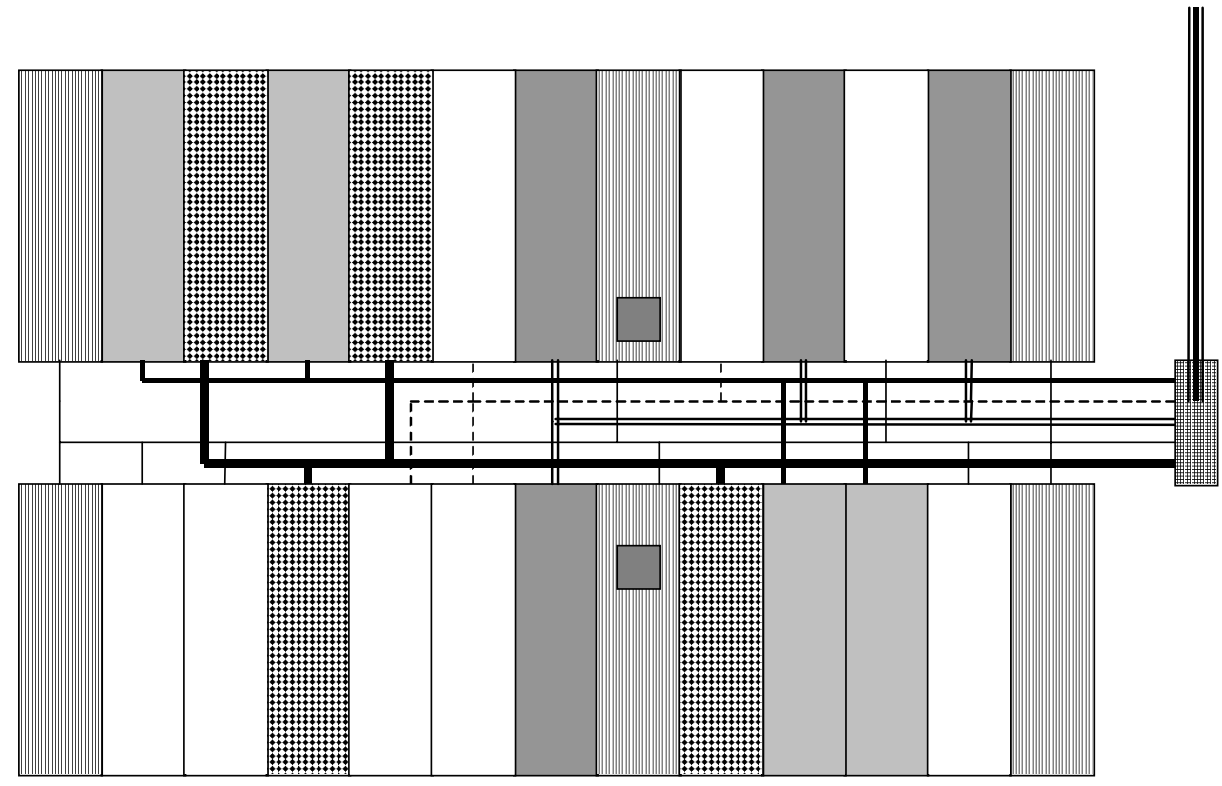

$\square \Rightarrow$ Bordaduras + Parcelas centrais com os dois microlisímetros; 娄的 $\Rightarrow 80 \% \mathrm{ETE} ; \square \Rightarrow 64 \% \mathrm{ETE} ; \square \Rightarrow 15 \% \mathrm{ETE}$

Figura 7 - Desenho ilustrativo da localização das parcelas de bordaduras, parcelas com os microlisímetros e tratamentos na área experimental. 
Apesar de serem ilustradas 26 parcelas (Figura 7), cabe ressaltar que as 4 parcelas externas são as bordaduras e as duas internas são as parcelas que contém os microlisímetros. Essas 6 parcelas receberam lâminas de irrigação equivalente a $80 \%$ da ETc.

\subsection{Instalação e manejo da cultura}

A cultura da estévia (Stevia rebaudiana Bert.) foi instalada em campo aberto no ano de 1999. As mudas foram produzidas a partir de sementes oriundas do Paraguai. As plantas utilizadas para fornecerem as sementes não tinham sido melhoradas geneticamente, ou seja, foi utilizada a própria espécie nativa. Segundo Carneiro et al. (1997), do segundo ao quinto ano, a cultura da estévia atinge a estabilidade na produção. As avaliações apresentadas no presente trabalho correspondem ao segundo ano de cultivo (2000). Uma vista parcial do experimento é apresentada na Figura 8, ilustrando a cultura 15 dias após o corte de uniformização.

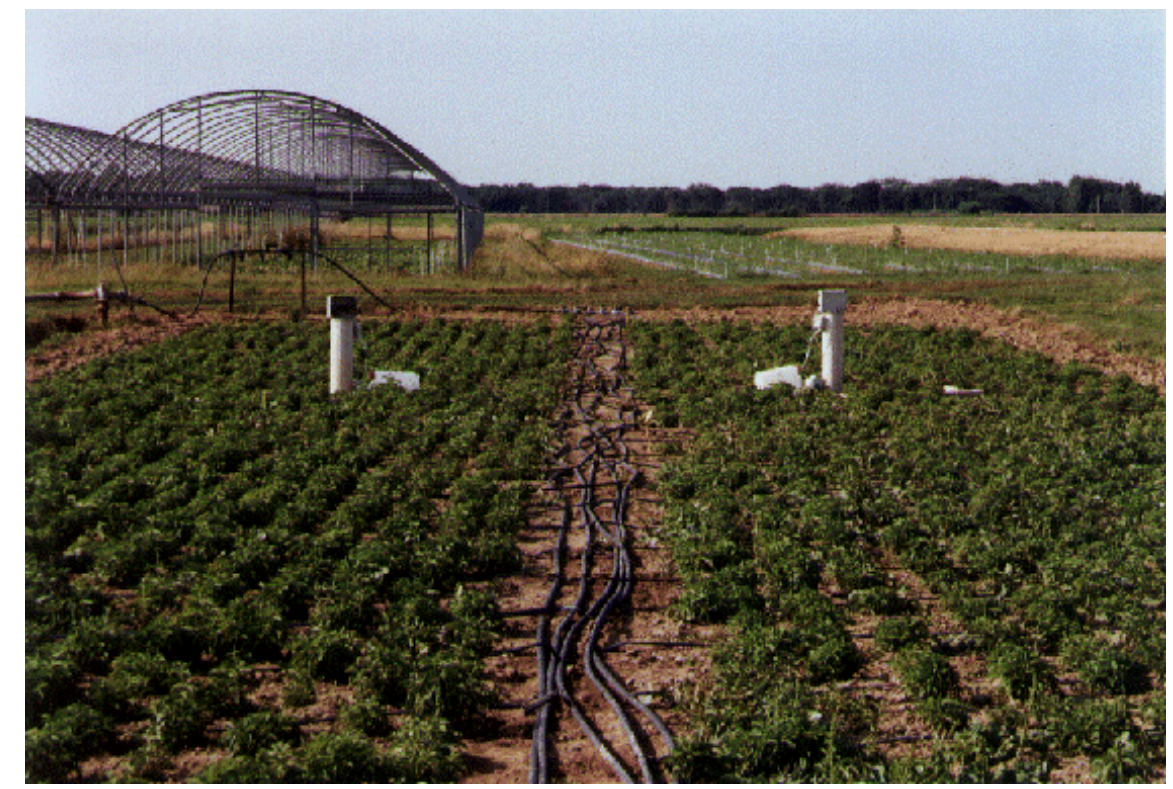

Figura 8 - Uniformidade das plantas de estévia 15 dias após o corte de uniformização, realizado em 01 de junho de 2000. 
Após o corte de uniformização, foi realizada uma irrigação com 20 $\mathrm{mm}$, visando favorecer o rebrote uniforme. Nessa oportunidade, também foi aplicada a primeira fertirrigação. Toda semana, foram realizadas capinas para eliminar as plantas invasoras. Todas as manhãs, às 8 horas, foram realizadas as leituras do volume de água consumida em cada microlisímetro. Este controle foi realizado através da contagem de pulsos dos contadores nas 24 horas antecedentes e multiplicado pelo volume de água fornecido em cada pulso (60 $\mathrm{cm}^{3}$ ). $\mathrm{O}$ volume total de água foi dividido pela área ocupada pelo microlisímetro, determinando assim a lâmina evapotranspirada em mm.dia ${ }^{-1}$.

Diariamente, realizou-se a medida da altura do lençol freático. Esta avaliação foi necessária por causa da proximidade do Rio Arno, distante a 200 $\mathrm{m}$ da área de pesquisa e pouca diferença de nível entre o leito do rio e o experimento.

\subsection{Irrigações nos diversos tratamentos}

As lâminas de irrigação foram repostas a cada 3 dias, de tal forma que - volume de água aplicado atingisse maior profundidade do solo e, consequentemente, toda a zona radicular. Apenas em quatro oportunidades as irrigações foram efetuadas a cada 4 dias, devido a pequena evapotranspiração medida pelos microlisímetros.

O volume de água aplicado nas parcelas experimentais foi controlado por cinco hidrômetros instalados após o cabeçal de controle. Cada tratamento com 5 parcelas era controlado por um hidrômetro.

\subsection{Fertirrigação}

A água de irrigação e os fertilizantes foram aplicados através de linhas de polietileno, com gotejadores distanciados a $30 \mathrm{~cm}$. Para cada duas fileiras de estévia instalou-se uma linha de irrigação A pressão empregada no sistema foi 
de $85 \mathrm{kPa}$. A vazão por gotejador, na referida pressão, foi de 1 litro por hora.

Os nutrientes foram aplicados 3 vezes durante o ciclo com um dosador tipo Venturi. A primeira, após o corte de uniformização e as duas seguintes aos 25 e 50 dias. As dosagens de nutrientes seguiram a orientação descrita por Lima Filho et al. (1997) para a cultura da estévia e estão especificadas na Tabela 6. O fertilizantes empregados foram: nitrato de cálcio, uréia, fosfato monoamônio (MAP), cloreto de potássio, sulfato de magnésio e composto solúvel de micronutrientes. O procedimento de aplicação está ilustrado na Figura 9.

Tabela 6. Macronutrientes e micronutrientes $\left(\mathrm{kg}_{\mathrm{ha}} \mathrm{h}^{-1}\right)$ exigidos pela cultura da estévia (Lima Filho et al. 1997).

\begin{tabular}{llllllllllll}
\hline Nutriente & $\mathrm{N}$ & $\mathrm{P}$ & $\mathrm{K}$ & $\mathrm{Ca}$ & $\mathrm{Mg}$ & $\mathrm{S}$ & $\mathrm{B}$ & $\mathrm{Cu}$ & $\mathrm{Fe}$ & $\mathrm{Mn}$ & $\mathrm{Zn}$ \\
Kg.ha $^{-1}$ & 194 & 23 & 118 & 47 & 11 & 11 & 0,27 & 0,090 & 1,85 & 0,60 & 0,04 \\
\hline
\end{tabular}

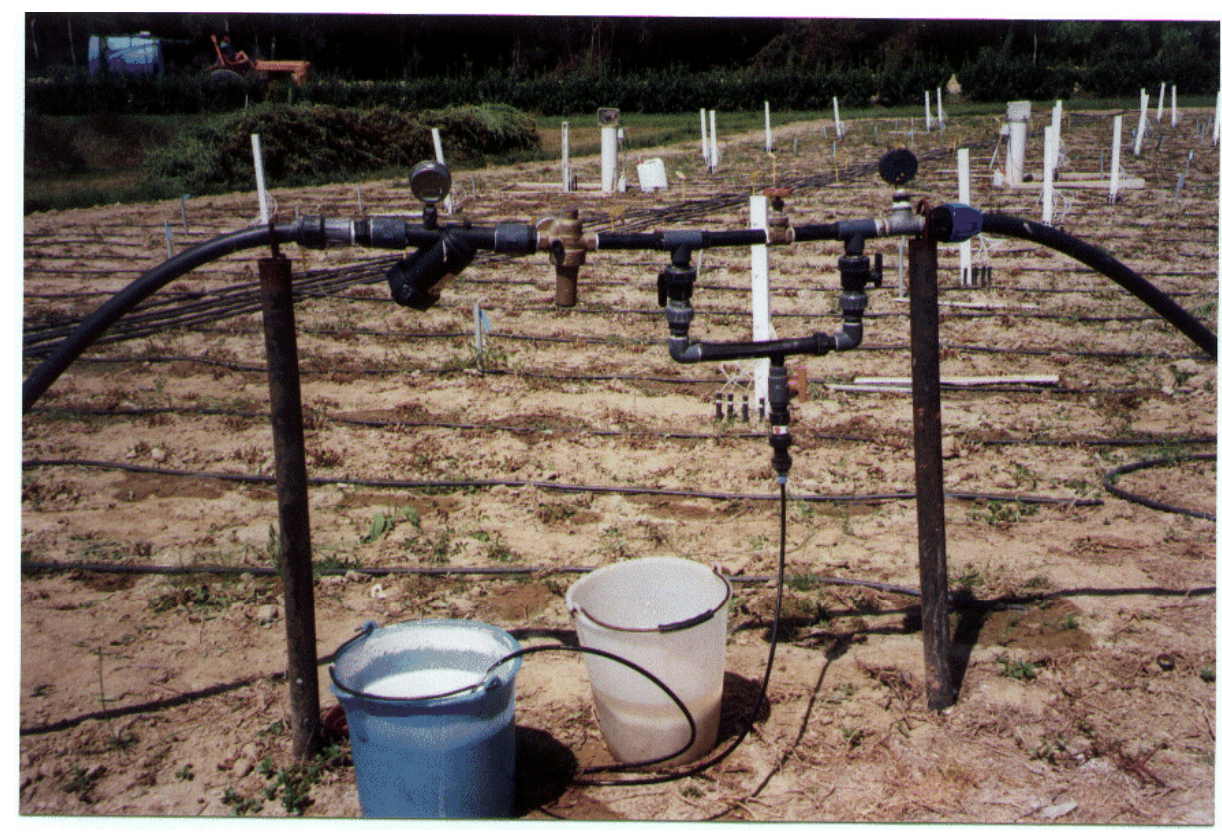

Figura 9 - Sistema de fertirrigação tipo Venturi, distribuição dos tensiômetros e microlisímetros no campo experimental. 


\subsection{Avaliação da disponibilidade hídrica}

As tensões de água no solo foram monitoradas por meio de tensiômetros de mercúrio instalados a $10 \mathrm{~cm}, 20 \mathrm{~cm}, 30 \mathrm{~cm}$ e $40 \mathrm{~cm}$ de profundidade, totalizando 88 tensiômetros. A distribuição foi de 4 tensiômetros por parcelas e 4 em cada microlisímetro. Nos microlisímetros, as profundidades de instalação foram de $5 \mathrm{~cm}, 10 \mathrm{~cm}, 15 \mathrm{~cm}$ e $20 \mathrm{~cm}$. Durante o período, foram realizadas 4 determinações da umidade pelo método gravimétrico, visando correlacionar às tensões medidas pelos tensiômetros. Cabe ressaltar que tensões acima de $80 \mathrm{kPa}$ foram correlacionadas com valores de umidade gravimétrica do solo versus a curva de retenção de água no solo determinada em laboratório.

A escolha dessas profundidades de instalação seguiram orientação de Bertonha et al. (1986). Estes autores afirmam que a maior parte do sistema radicular da cultura da estévia encontra-se até $25 \mathrm{~cm}$. Nesse sentido, Carneiro (1990) cita que, após o primeiro corte, a cultura apresenta um sistema radicular fasciculado e, mesmo sendo cultura perene, as raízes concentram-se na camada superficial do solo.

Os tensiômetros foram colocados entre as plantas de estévia na própria linha, visando determinar o potencial mátrico na região em que as raízes da estévia se encontravam. O detalhe da instalação pode ser visualizado na Figura 10. A equação para a determinação do potencial matricial foi:

$$
\psi_{m}=-12,6 h+h_{1}+h 2
$$

onde:

$\Psi_{\mathrm{m}}$ - potencial matricial $(\mathrm{kPa})$;

h - altura da coluna de mercúrio $(\mathrm{cm})$, 
$\mathrm{h}_{1}$ - diferença de nível entre o centro da cápsula e a superfície do solo, $\mathrm{h}_{2}$ - diferença de nível entre a superfície do solo e a cuba com mercúrio.

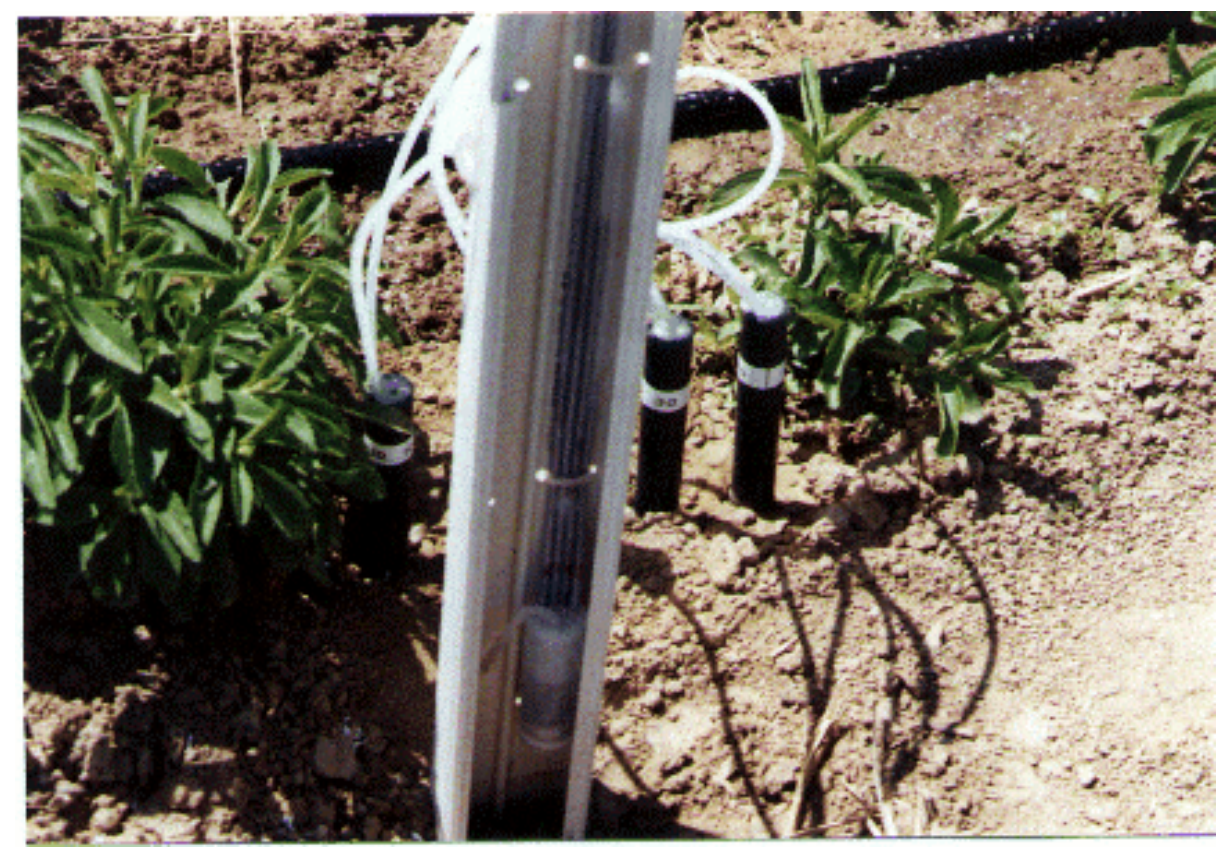

Figura 10 - Detalhe dos tensiômetros instalados na fila, entre as plantas da estévia.

\subsection{Análise de crescimento}

A análise de crescimento foi realizada em três oportunidades, durante o ciclo da cultura: aos 25 dias, aos 50 dias e aos 75 dias do corte de uniformização. O parâmetro adotado foi a determinação da a área foliar (AF) de cada planta. O processo para o cálculo do IAF foi a contagem das folhas por planta. A seguir, elas foram divididas em 3 classes de tamanho (Figura 11). A partir das medidas de área foliar de 30 folhas estabeleceu-se a média para cada uma das classes.

Posteriormente, foi determinado o índice de área foliar (IAF) por meio do quociente entre a área total das folhas da planta e a área total do terreno 
disponível para ocupação da parte aérea da planta, conforme a equação 2 , utilizada por Tozzi (1995).

$$
I A F=\frac{A}{A t}
$$

onde:

$A=$ superfície foliar total da planta $\left(\mathrm{cm}^{2}\right)$;

$A_{t}=$ área do terreno disponível para ocupação da parte aérea da planta $\left(\mathrm{cm}^{2}\right)$.

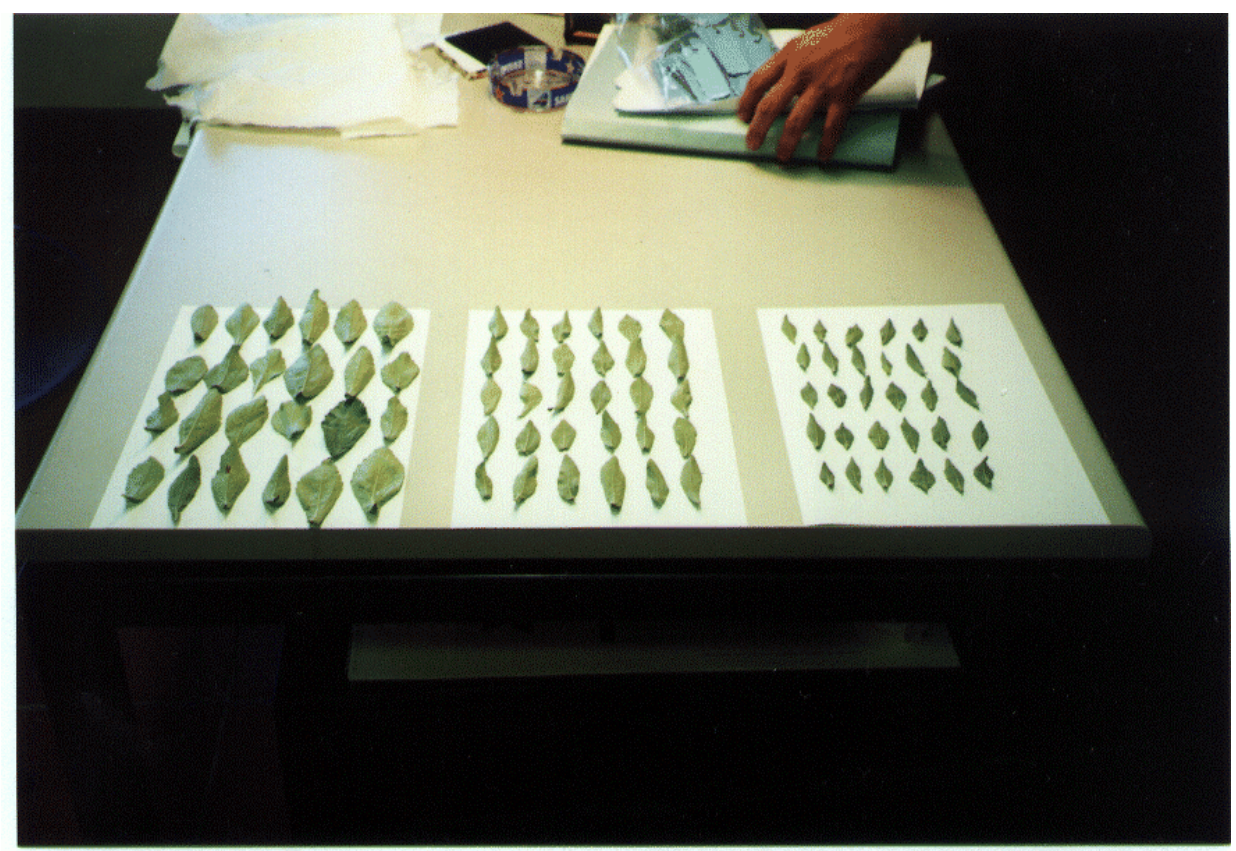

Figura 11 - Divisão das 3 classes de tamanho das folhas da estévia, utilizadas para a determinação do índice de área foliar.

Optou-se pela avaliação das mesmas plantas durante todo o ciclo. Tal decisão justifica-se pela grande variabilidade das plantas na área experimental. Qualquer método destrutivo causaria a perda da confiabilidade nos dados encontrados. Outro aspecto a se observar é o grande número de folhas por 
planta, acima de 3.000 folhas. Este fato tornaria inviável a determinação da área foliar pela medição da área de cada uma das folhas.

\subsection{Determinação da produção de estévia}

A colheita da estévia foi realizada a 80 dias após o corte de uniformização. Foram retiradas, ao acaso, 10 plantas por parcela. O ponto de colheita foi estabelecido quando $10 \%$ das plantas começaram a florescer. Esta fase coincide com a maior produção de massa seca e de concentração de esteviosídeo nas folhas.

Após o corte das plantas, fez-se o desfolhamento, separando as folhas do caule. Todo material foi para secar em estufa plástica (temperatura até $50{ }^{\circ} \mathrm{C}$ ) para a pré-secagem e, posteriormente, em estufa de secagem a temperatura de $65{ }^{\circ} \mathrm{C}$ até o peso se tornar constante. A seguir, as folhas foram trituradas e secadas novamente.

A produção de matéria seca por parcela foi calculada com esse material, tanto dos 5 tratamentos como do interior dos microlisímetros.

Após a secagem das folhas e caules, a relação entre folha e caule foi determinada, com o intuito de verificar a influência da disponibilidade hídrica na produção de folhas e caule e sua correlação.

Após a referida colheita, houve uma nova rebrota, cuja produção de massa seca de folhas foi avaliada novamente. Esta avaliação foi efetuada para verificar a viabilidade de se efetuar duas colheitas na região pesquisada.

\subsection{Análise de esteviosídeo}

As análises de esteviosídeo foram realizadas pelo método HPLC (High Performance Liquid Chromatographic), utilizando como padrão o esteviosídeo à $97 \%$ em coluna $\mathrm{R}-\mathrm{NH}_{2}$. Essas análises foram realizadas pela Universidade de Milão. Devido ao alto custo do método, houve somente 2 
repetições por tratamento.

\subsection{Eficiência do uso da água (EUA)}

A eficiência de uso de água é a relação entre o rendimento de massa seca de folhas e a água consumida no processo de evapotranspiração (Begg e Turner, 1976). Para o cálculo da EUA, foi empregada a relação utilizada por Frizzone (1986):

$$
E U A=\frac{Y}{V+T+E+D}
$$

sendo,

EUA - eficiência do uso da água, $\mathrm{kg} \cdot \mathrm{mm}^{-1} \cdot \mathrm{ha}^{-1}$;

$\mathrm{Y}$ - rendimento de massa seca, $\mathrm{kg} \cdot \mathrm{ha}^{-1}$;

$\mathrm{V}$ - água para o crescimento, $\mathrm{mm}$;

$\mathrm{T}$ - água para transpiração, $\mathrm{mm}$;

E - água evaporada da superfície do solo, $\mathrm{mm}$;

$\mathrm{D}$ - água perdida por drenagem, $\mathrm{mm}$.

O denominador da equação (3) foi representado pela lâmina total aplicada nos microlisímetros e nos respectivos tratamentos.

Este coeficiente permite ao produtor decidir sobre o nível de investimento para uma determinada região em função dos custos da água e operação do sistema de irrigação, frente os preços obtidos pelo produto versus o rendimento de folhas e o teor de esteviosídeo.

\subsection{Avaliação do sistema de irrigação}

A uniformidade da aplicação da água de irrigação para o sistema de gotejamento foi avaliada por meio do Coeficiente de Uniformidade de 
Christiansen, calculado pela equação:

$$
C U C=100\left(1-\frac{\sum_{i=1}^{n}\left|X_{i}-\bar{X}\right|}{n \cdot \bar{X}}\right)
$$

em que:

CUC - coeficiente de uniformidade de Christiansen (\%);

$x_{i}$ - volume de água $i\left(\mathrm{~cm}^{3}\right)$;

$\mathrm{n}$ - número de amostras;

$\mathrm{x}$ - valor médio da amostra $\left(\mathrm{cm}^{3}\right)$.

A uniformidade de aplicação da água foi determinada no início do período de irrigação, na primeira semana de junho e após o final da condução do experimento, na primeira semana de setembro.

\subsection{Controle de pragas, doenças e plantas invasoras}

Durante a condução do experimento, as principais pragas que ocorreram foram pequenos caracóis, do gênero Helix sp. Os mesmos atacaram a cultura logo após o corte de uniformização, porém foram facilmente controladas com o uso de iscas granuladas.

Ao passo que a principal doença foi o aparecimento de fusariose. No entanto, apenas 5 plantas foram infectadas de um total de 2500 plantas instaladas na área experimental. O controle adotado foi a retirada das plantas atacadas para a erradicação da doença, não permitindo a disseminação no experimento.

Já, o controle de invasoras foi realizado manualmente. O sistema de irrigação por gotejamento auxiliou no controle das ervas daninhas, pois, as mesmas, somente germinavam e se desenvolviam onde havia umidade. 


\subsection{Método Penman-Monteith-FAO}

A evapotranspiração de referência (ETo) foi determinada pelo método Penman-Monteith-FAO descrito por Allen et al. (1998). Os autores definem a evapotranspiração de referência como aquela de uma cultura de referência hipotética com altura de $0,12 \mathrm{~m}$, resistência superficial de $70 \mathrm{~s} . \mathrm{m}^{-1}$, e albedo igual a 0,23 .

A densidade de fluxo de calor no solo foi considerada nula para períodos de 1 dia, pois o balanço de calor no solo entre o dia e a noite ser próximo a zero.

Este método foi escolhido uma vez que, segundo Smith et al. (1996), é o que apresenta melhor correlação entre dados estimados e medidos por lisímetros.

A equação geral para determinar a evapotranspiração de referência é:

$$
\mathrm{ETo}=\frac{0,408(\mathrm{Rn}-\mathrm{G})+\frac{900}{\mathrm{~T}+273} \mathrm{U}_{2}\left(\mathrm{e}_{\mathrm{s}}-\mathrm{e}_{\mathrm{a}}\right)}{\Delta+\gamma\left(1+0,34 \mathrm{U}_{2}\right)}
$$

onde:

ETo - evapotranspiração de referência $\left(\mathrm{mm} \cdot \mathrm{dia}^{-1}\right)$;

$\mathrm{Rn}$ - radiação líquida na superfície do solo $\left(\mathrm{MJ}^{\mathrm{m}} \mathrm{m}^{-2} \cdot \mathrm{dia}^{-1}\right)$;

$\mathrm{G}$ - densidade de fluxo de calor no solo $\left(\mathrm{MJm}^{-2} \cdot \mathrm{dia}^{-1}\right)$;

$\mathrm{T}$ - temperatura do ar a $2 \mathrm{~m}$ de altura $\left({ }^{\circ} \mathrm{C}\right)$;

$\mathrm{U}_{2}$ - velocidade do vento a 2 metros de altura $\left(\mathrm{m} . \mathrm{s}^{-1}\right)$;

$\mathrm{e}_{\mathrm{s}}$ - pressão de saturação de vapor $(\mathrm{kPa})$;

$\mathrm{e}_{\mathrm{a}}$ - pressão de vapor atual $(\mathrm{kPa})$;

$\left(e_{s}-e_{a}\right)$ - déficit de pressão de saturação de vapor de água $(k P a)$;

$\Delta$ - inclinação da curva de pressão de vapor $\left(\mathrm{kPa}^{\circ} \mathrm{C}^{-1}\right)$;

$\gamma$ - constante psicrométrica. 
Para o cálculo da radiação líquida, é necessário determinar a radiação extraterrestre, radiação solar e fotoperíodo.

A radiação extraterrestre diária $\left(R_{a}\right)$ é encontrada aplicando-se a equação:

$$
R_{a}=\frac{24(60)}{\pi} G_{s c} d_{r}\left[\varpi_{s} \operatorname{sen}(\varphi) \cdot \operatorname{sen}(\delta)+\cos (\varphi) \cos (\delta) \operatorname{sen}\left(\varpi_{s}\right)\right]
$$

sendo:

$R_{a}$ - radiação extraterrestre para o período de 24 horas $\left(M J \cdot m^{-2} \cdot d^{-1} a^{-1}\right.$;

$\mathrm{G}_{\mathrm{sc}}$ - constante solar $=0,0820 \mathrm{MJ} \cdot \mathrm{m}^{-2} \mathrm{~min}^{-1}$;

$\mathrm{d}_{\mathrm{r}}$ - distância relativa terra-sol;

$\omega_{\mathrm{s}}$ - ângulo horário solar (em radianos);

$\varphi$ - latitude em radianos;

$\delta$ - declinação solar em radianos.

A distância relativa entre a terra e o sol $\left(d_{r}\right)$ é obtida:

$$
d_{r}=1+0,033 \cos \left(\frac{2 \pi}{365} J\right)
$$

onde:

$\mathrm{J}$ - o número do dia do ano entre 01 de janeiro e 31 de dezembro do respectivo ano, o mesmo pode ser encontrado pelas seguintes relações:

$\mathrm{J}=$ INT $(275 . \mathrm{M} / 9-30+\mathrm{D})-2$

INT - inteiro.

onde $\mathrm{M}$ é o número do mês e $\mathrm{D}$ o dia. Se $\mathrm{M}$ é menor que $3, \mathrm{~J}=\mathrm{J}+2$.

A declinação solar $(\delta)$, expressa em radianos, é calculada por: 


$$
\delta=0,409 \operatorname{sen}\left(\frac{2 \pi}{365} J-1,39\right)
$$

O ângulo horário solar $\left(\omega_{\mathrm{s}}\right)$, em radianos, é obtido:

$$
\omega_{s}=\arccos [-\tan (\varphi) \tan (\delta)]
$$

O número de horas de brilho solar, $\mathrm{N}$, é obtido:

$$
N=\frac{24}{\pi} \omega_{s}
$$

$\mathrm{N}$ - horas de brilho solar.

A radiação solar em dias claros $\left(R_{\text {so }}\right)$ é calculada:

$$
R_{s o}=\left(0,75+2 \cdot 10^{-5} \cdot z\right) \cdot R a
$$

sendo:

$\mathrm{z}$ - altitude (m).

A radiação líquida $(R n)$ é a diferença entre a radiação líquida de ondas curtas (Rns) que chegam ao solo e a radiação líquida de ondas longas refletidas $(\mathrm{Rnl})$.

$$
R n=R n s-R \mathrm{nl}
$$

onde as unidades da radiação estão em $\mathrm{MJ} \cdot \mathrm{m}^{-2} \cdot \mathrm{dia}^{-1}$. 
A radiação solar líquida de ondas curtas $\left(R_{n s}\right)$ é obtida por:

$$
R_{n s}=(1-\alpha) R_{s}
$$

onde:

$\alpha$ - coeficiente de reflexão ou albedo ( 0,23 para a cultura de referência);

$R_{s}$ - radiação global incidente $\left(M^{-2} \mathrm{dia}^{-1}\right)$.

A taxa de emissão de energia de onda longa é proporcional à temperatura absoluta da superfície considerada elevada a quarta potência e pode ser expressa quantitativamente pela lei de Stefan-Boltzmann. Assim, a determinação de Rnl deve ser feita ajustando-se a taxa de emissão de ondas em função da pressão atual de vapor e radiação solar:

$$
R n l=\sigma\left(\frac{T \max \cdot K^{4}+T \min \cdot K^{4}}{2}\right)\left(0,34-0,14 e a^{0,5}\right)\left(1,35 \frac{R s}{R s o}-0,35\right)
$$

sendo:

Rnl - radiação líquida $\left(\mathrm{MJ} \cdot \mathrm{m}^{-2} \cdot \mathrm{dia} \mathrm{a}^{-1}\right)$;

$\sigma$ - Stefan-Boltzmann $\left(4,903 \cdot 10^{-9} \mathrm{MJK}^{-4} \cdot \mathrm{m}^{-2} \cdot \mathrm{dia}^{-1}\right)$;

Tmax, $\mathrm{K}$ - temperatura máxima absoluta no período de 24 horas $\left(\mathrm{K}={ }^{\circ} \mathrm{C}\right.$ $+273,16)$;

Tmin, $\mathrm{K}$ - temperatura mínima absoluta no período de 24 horas $\left(\mathrm{K}={ }^{\circ} \mathrm{C}\right.$ $+273,16)$;

$e_{a}$ - pressão atual de vapor $(\mathrm{kPa})$;

$R_{s} / R_{\text {so }}$ - radiação relativa de ondas curtas (limitado para $\leq 1,0$ );

$\mathrm{R}_{\mathrm{s}}$ - radiação solar medida $\left(\mathrm{MJ} \cdot \mathrm{m}^{-2} \cdot \mathrm{dia}^{-1}\right)$;

$\mathrm{R}_{\mathrm{so}}$ - calculada (MJ.m $\mathrm{m}^{-2} \cdot \mathrm{dia}^{-1}$ ). 
A pressão atmosférica influencia na evapotranspiração e esta é função da altitude local, portanto, deve ser levada em consideração. Este parâmetro pode ser calculado com a relação que simplifica o comportamento de um gás ideal a uma temperatura de $20^{\circ} \mathrm{C}$ :

$$
P=101,3\left(\frac{293-0,0065 Z}{293}\right)^{5,26}
$$

em que:

$\mathrm{P}$ - pressão atmosférica $(\mathrm{kPa})$;

$Z$ - altitude (m).

A constante psicrométrica $(\gamma)$ é encontrada com a expressão:

$$
\gamma=\frac{c_{p} \cdot P}{\varepsilon \cdot \lambda}=0,665 \times 10^{-3} P
$$

onde:

$\gamma$ - constante psicrométrica $\left(\mathrm{kPa}^{\circ} \mathrm{C}^{-1}\right)$;

$\mathrm{P}$ - pressão atmosférica $(\mathrm{kPa})$;

$\lambda$ - calor latente de vaporização, 2,45 $\left(\mathrm{MJkg}^{-10} \mathrm{C}^{-1}\right)$;

$\mathrm{C}_{\mathrm{p}}$ - calor específico a constante de pressão, $1,013 \times 10^{-3}\left(\mathrm{MJkg}^{-10} \mathrm{C}^{-1}\right)$;

$\varepsilon$ - relação do peso molecular do vapor d'água/ar seco $=0,622$.

Por convenção, a temperatura padrão é medida a $2 \mathrm{~m}$ de altura, que representa um valor próximo a copa das plantas. A temperatura média do ar (Tmédia) é determinada aplicando:

$$
\text { Tmédia }=\frac{T \max +T \min }{2}
$$

sendo: 
Tmédia - temperatura média do dia $\left({ }^{\circ} \mathrm{C}\right)$;

Tmax - temperatura máxima do dia $\left({ }^{\circ} \mathrm{C}\right)$;

Tmin - temperatura mínima do dia $\left({ }^{\circ} \mathrm{C}\right)$.

A pressão de saturação de vapor para a temperatura do ar nos seus extremos (Tmax e Tmin) é encontrada com a equação:

$$
e^{o}(T)=0,6108 \exp \left[\frac{17,27 . T}{T+237,3}\right]
$$

onde:

$\mathrm{e}^{\mathrm{o}}(\mathrm{T})$ - pressão de saturação de vapor a temperatura do ar T (kPa);

$\mathrm{T}$ - temperatura do $\operatorname{ar}\left({ }^{0} \mathrm{C}\right)$;

exp. - 2,7183 (base do logaritmo natural);

Obs.: o $\mathrm{e}^{\mathrm{O}}(\mathrm{T})$ é calculado para a temperatura máxima e mínima.

O valor médio da pressão de saturação do vapor de água $\left(\mathrm{e}_{\mathrm{s}}\right)$ é dada por:

$$
e_{s}=\frac{e^{o}(T \max )^{+} e^{o}(T \min )}{2}
$$

A pressão atual de vapor, calculada com a umidade relativa do ar, é:

$$
e_{a}=\frac{e^{o}(T \min ) \frac{R H \max }{100}+e^{o}(T \max ) \frac{R H \min }{100}}{2}
$$

sendo:

$\mathrm{e}_{\mathrm{a}}$ - pressão de vapor atual $(\mathrm{kPa})$;

$e^{o}$ (Tmin) - pressão de saturação de vapor na temperatura mínima diária (kPa);

$\mathrm{e}^{\circ}$ (Tmax) - pressão de saturação de vapor na temperatura máxima diária (kPa);

RHmax - umidade máxima relativa (\%);

RHmin - umidade mínima relativa (\%). 
O déficit de pressão de vapor é a diferença entre a pressão de saturação de vapor e a pressão atual de vapor de água no ar. O seu valor, geralmente, é alto nas horas mais quentes e baixo na madrugada.

Para o cálculo da evapotranspiração, a inclinação da curva de relação entre pressão de vapor de saturação e temperatura $(\Delta)$ é necessária. Esta é calculada por:

$$
\Delta=\frac{4098\left[0,6108 \exp \left\{\frac{17,27 T}{T+237,3}\right\}\right]}{(T+237,3)^{2}}
$$

em que:

$\Delta$ - inclinação da curva de saturação de vapor a determinada temperatura $T$ $\left(\mathrm{kPa}^{\circ} \mathrm{C}^{-1}\right)$,

$\mathrm{T}$ - temperatura média $\left({ }^{\circ} \mathrm{C}\right)$,

$\exp (.)=2,$.7183 (base do logaritmo natural). 


\section{RESULTADOS E DISCUSSÃO}

Os resultados apresentados nas tabelas e figuras que seguem e após discutidos referem-se ao experimento realizado de primeiro de junho a 05 de outubro de 2000, compreendendo duas colheitas da cultura da estévia.

Primeiramente, serão discutidos os dados de consumo hídrico, medidos por meio dos dois microlisímetros e relacionados aos dados de ETo estimados pelo método Penman-Monteith, utilizados para o cálculo do Kc da cultura. Posteriormente, serão discutidos os aspectos de rentabilidade da cultura, índice de área foliar e teor de esteviosídeo, frente a diferentes lâminas de irrigação e potenciais matriciais de água no solo. Por último, serão apresentados os resultados de uma segunda colheita para a região de estudo, discutindo-se a viabilidade desta, sendo também relacionadas algumas recomendações para futuras pesquisas com a cultura da estévia.

\subsection{Consumo hídrico da cultura}

Os valores de consumo hídrico da cultura da estévia, determinados pelo microlisímetro de lençol freático constante, são apresentados na Tabela 7. Nos primeiros dias após o corte de uniformização, na fase de crescimento inicial, o consumo hídrico medido foi elevado, contrariando a expectativa inicial. Isto ocorreu principalmente devido a dois fatores, descritos a seguir.

O primeiro motivo refere-se ao volume gasto no preenchimento dos poros do solo (até o ponto de equilíbrio dos potenciais de água no solo saturação), que inicialmente estavam vazios. Este fator teve influência 
Tabela 7. Consumo hídrico da cultura da estévia nos microlisímetros ( $\left.\mathrm{mm} \cdot \mathrm{dia}^{-1}\right)$.

\begin{tabular}{cccc}
\hline Período & Microlisimetro 1 & Microlisimetro 2 & Média \\
\hline $06-10 / 06 / 00$ & 7,85 & 7,89 & 7,87 \\
$11-15 / 06 / 00$ & 7,79 & 7,95 & 7,87 \\
$16-20 / 06 / 00$ & 7,56 & 7,03 & 7,30 \\
$21-25 / 06 / 00$ & 6,57 & 5,72 & 6,15 \\
$26-30 / 06 / 00$ & 5,89 & 4,82 & 5,35 \\
$01-05 / 07 / 00$ & 5,79 & 4,99 & 5,39 \\
$06-10 / 07 / 00$ & 5,83 & 5,22 & 5,53 \\
$11-15 / 07 / 00$ & 5,19 & 4,93 & 5,06 \\
$16-20 / 07 / 00$ & 4,72 & 4,51 & 4,62 \\
$21-25 / 07 / 00$ & 5,66 & 5,90 & 5,78 \\
$26-30 / 07 / 00$ & 4,59 & 4,52 & 4,55 \\
$31-04 / 08 / 00$ & 5,94 & 4,92 & 5,43 \\
$05-09 / 08 / 00$ & 6,77 & 6,44 & 6,61 \\
$10-14 / 08 / 00$ & 4,35 & 4,37 & 4,36 \\
$15-19 / 08 / 00$ & 5,04 & 5,19 & 5,11 \\
$20-22 / 08 / 00$ & 5,46 & 6,41 & 5,94 \\
Total (mm) & 475,06 & 454,05 & 464,55 \\
Média & 5,94 & 5,68 & 5,81 \\
\hline
\end{tabular}

especialmente nos primeiros dias. Este fato é observado com maior clareza na Figura 12.

O segundo fator, e o mais importante, ocorreu devido à elevada umidade do solo, a qual favoreceu a evaporação da água no interior do microlisímetro. Nessa condição, a evaporação tende a ocorrer de forma similar ou até mais acentuada que em um evaporímetro do tipo tanque. Isto explica-se pela proximidade do lençol freático $(35 \mathrm{~cm})$ à superfície do solo e pela cor cinza escura do solo, que favorece a absorção de grande quantidade de energia solar. Na fase inicial (mês de junho), os dias apresentaram uma média de 15,3 horas de sol, com grande energia incidente, o que favorece a evaporação da água.

Souza (1992) também encontrou evapotranspiração inicial elevada para o algodoeiro, sendo 3 vezes superior quando o lençol freático esteve a 25 $\mathrm{cm}$, ao se comparar ao lençol freático a $75 \mathrm{~cm}$. Os valores passaram de 1,5 $\mathrm{mm}$.dia ${ }^{-1}$ para $4,5 \mathrm{~mm} . \mathrm{dia}^{-1}$. O autor cita que esta diferença ocorreu somente na fase inicial da cultura até o momento em que esta apresentou cobertura total do 


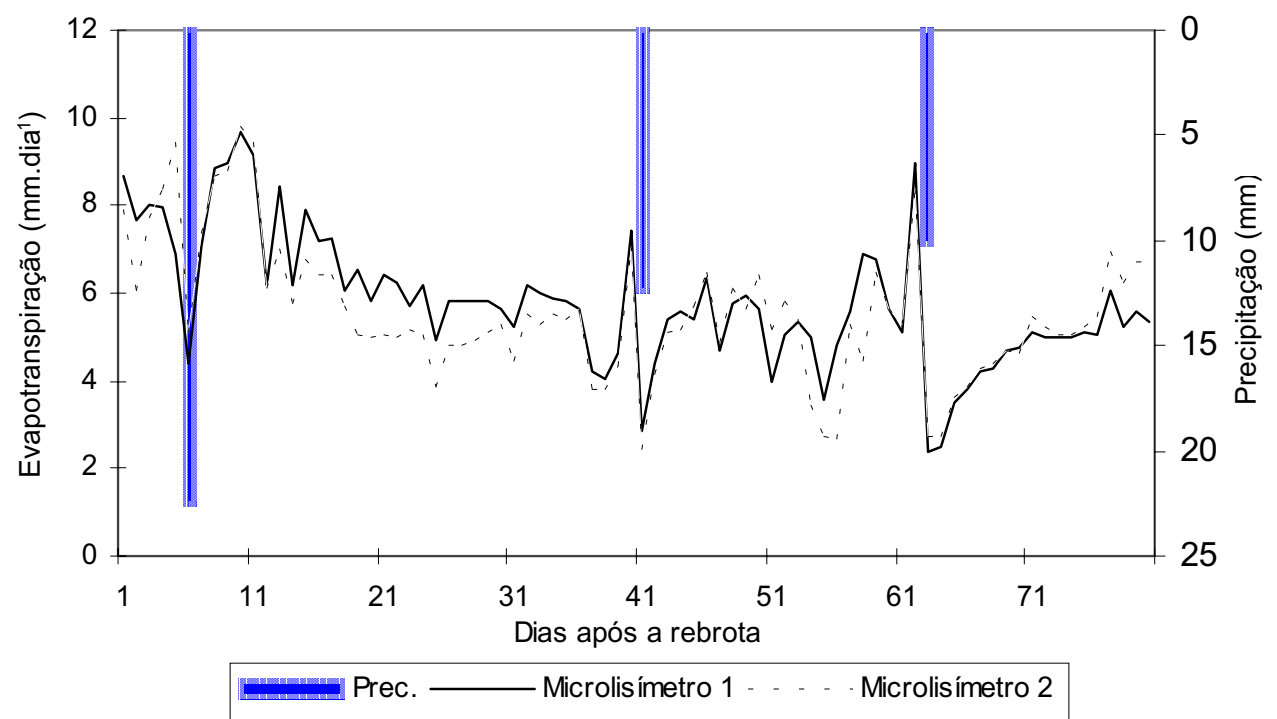

Figura 12 - Variação do consumo diário de água, durante o período de cultivo, nos 2 microlisímetros.

solo. A partir desta fase, a evapotranspiração foi semelhante nas profundidades de lençol freático testadas.

No presente trabalho, um aspecto que favoreceu a evaporação foi a elevada percentagem de silte no solo (39\%), somado aos $10 \%$ de argila, ambas partículas finas do solo, as quais aumentam as perdas pela ação do fluxo capilar no solo. Uma forma de eliminar este problema seria a adição de uma pequena camada de areia grossa (cerca 2 a $3 \mathrm{~cm}$ ) na parte superficial do microlisímetro, reduzindo a ação da capilaridade na evaporação. Porém, esta alternativa não solucionaria o problema de deficiência de aeração do solo. Para equacionar este problema seria preciso rebaixar a altura do lençol freático, o que será discutido posteriormente.

De acordo com a Figura 12, verifica-se uma maior flutuação no consumo hídrico da cultura próxima à ocorrência das três precipitações. Tal fato ocorreu devido ao armazenamento de água no solo durante as precipitações, mantendo o lençol freático elevado $e$, apesar de estar ocorrendo 
evapotranspiração, não houve contabilização de consumo hídrico, pois os poros dos microlisímetros estavam saturados.

Na Figura 13, são ilustrados os dados médios de 5 dias (pêntadas), calculados a partir dos dados diários da Figura 12. Dessa forma, obtém-se maior uniformidade nos dados e minimiza-se os efeitos das chuvas ocorridas no período. Becker (1990) e Sousa (1992) ressaltam ser importante o controle da entrada de água nos lisímetros por ocasião das precipitações, visando evitar a perda de leituras. Além disso, Barbieri (1981) cita a importância de realizar a análise dos dados nos lisímetros de lençol freático constante para períodos de 5 dias ou mais, evitando grande oscilação dos valores e maior representatividade nos dados de ETc.

Comparando-se a evapotranspiração para as três fases da cultura (025 dias; 25-50 dias; 50-80 dias), observou-se que houve uma redução na evapotranspiração do período inicial para o período intermediário e, um pequeno incremento na ETc para o período final de cultivo.

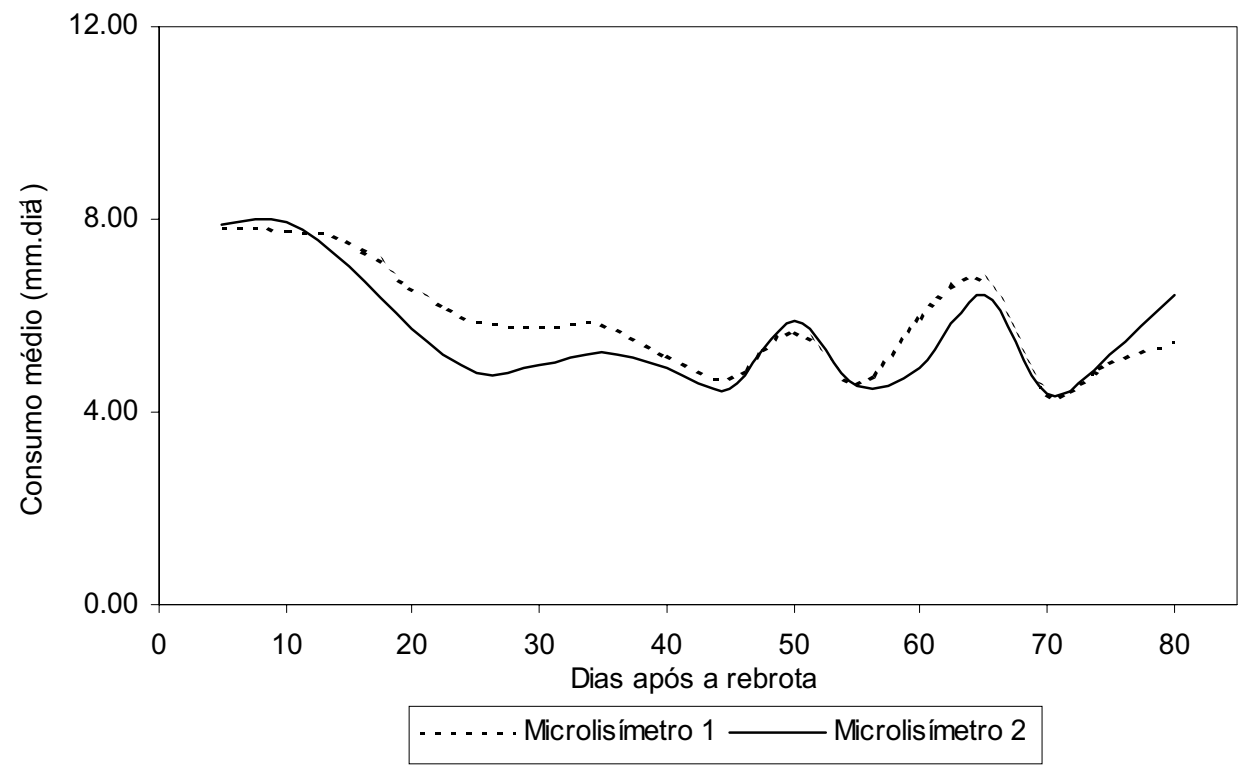

Figura 13 - Variação de consumo de água durante o período de cultivo, nos 2 microlisímetros, com dados médios de 5 dias. 
Nota-se ainda na Figura 13 que os dois microlisímetros apresentaram medições semelhantes durante os 80 dias do ciclo da cultura, com uma lâmina total de $475 \mathrm{~mm}$ para o microlisímetro 1 e $454 \mathrm{~mm}$ para o microlisímetro 2, sendo a média de ambos 464,5 mm (Tabela 7). Já na Figura 14, observa-se a correlação existente entre os dados dos 2 microlisímetros, com $r^{2}$ de 0,79 , a qual foi altamente significativa $(p<0,01)$.

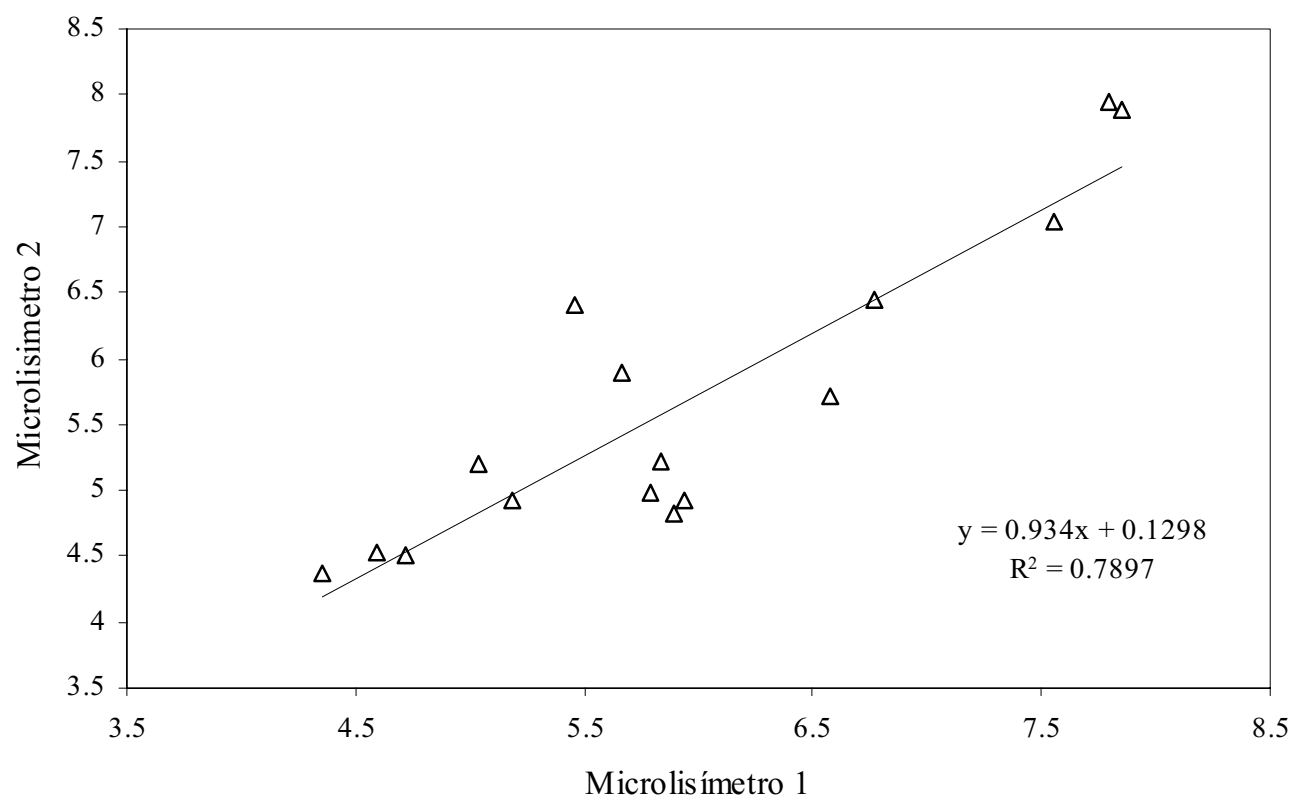

Figura 14 - Correlação entre os dados de evapotranspiração real da cultura coletados nos dois microlisímetros.

\subsection{Evapotranspiração de referência e coeficiente de cultura da estévia}

$\mathrm{Na}$ Tabela 8, são apresentados os valores de evapotranspiração de referência, calculados pelo método Penman-Monteith-FAO (Allen et al 1998). É possível observar que os resultados de ETc, medidos pelos microlisímetros, estão superestimados na fase inicial, sendo maiores que os de ETo. Nessa fase, para a maioria das culturas, o que se espera é que os valores de ETo 
Tabela 8. Consumo de água médio nos microlisímetros, evapotranspiração de referência e Kc médio para períodos de 5 dias.

\begin{tabular}{cccc}
\hline Data & Microlisímetro $\left(\mathrm{mm} . d i a^{-1}\right)$ & ETo $\left(\mathrm{mm} \cdot\right.$ dia $\left.^{-1}\right)$ & Kc médio \\
\hline $06-10 / 06 / 00$ & 7,87 & 5,17 & 1,52 \\
$11-15 / 06 / 00$ & 7,87 & 3,73 & 2,11 \\
$16-20 / 06 / 00$ & 7,30 & 5,64 & 1,29 \\
$21-25 / 06 / 00$ & 6,15 & 5,06 & 1,21 \\
$26-30 / 06 / 00$ & 5,35 & 4,85 & 1,10 \\
$01-05 / 07 / 00$ & 5,39 & 5,06 & 1,06 \\
$06-10 / 07 / 00$ & 5,53 & 4,78 & 1,16 \\
$11-15 / 07 / 00$ & 5,06 & 4,05 & 1,25 \\
$16-20 / 07 / 00$ & 4,62 & 5,10 & 0,90 \\
$21-25 / 07 / 00$ & 5,78 & 4,41 & 1,31 \\
$26-30 / 07 / 00$ & 4,55 & 5,05 & 0,90 \\
$31-04 / 08 / 00$ & 5,43 & 4,30 & 1,26 \\
$05-09 / 08 / 00$ & 6,61 & 4,36 & 1,52 \\
$10-14 / 08 / 00$ & 4,36 & 4,62 & 0,94 \\
$15-19 / 08 / 00$ & 5,11 & 4,83 & 1,06 \\
$20-22 / 08 / 00$ & 5,94 & 4,57 & 1,30 \\
Total & 464,55 & 377,92 & \\
Média & 5,81 & 4,72 & 1,23 \\
\hline
\end{tabular}

sejam maiores que os de ETc em razão das culturas estarem em período inicial de crescimento. Porém, como comentado anteriormente, os problemas de evaporação excessiva, devidos à proximidade do lençol freático da superfície, elevaram os valores de ETc.

Problema semelhante foi observado por Fontes (1996), estudando o consumo hídrico da couve brócolo, onde a superestimativa de ETc foi de $20 \%$ durante o ciclo da cultura, quando a altura do lençol freático passou de $50 \mathrm{~cm}$ para $40 \mathrm{~cm}$. As maiores superestimativas ocorreram na fase inicial da cultura. Valores superestimados de ETc também foram encontrados por Valadão (1995), o qual mediu a ETc do feijoeiro com este tipo de lisímetro. Os valores encontrados por este autor foram $55 \%$ superiores quando o lençol freático passou de 75 para $50 \mathrm{~cm}$ de profundidade.

Após os 25 dias de cultivo, observa-se pelas Figuras 15 e 16, que os dados de evapotranspiração da cultura apresentam melhor correlação com os dados estimados de evapotranspiração de referência. 


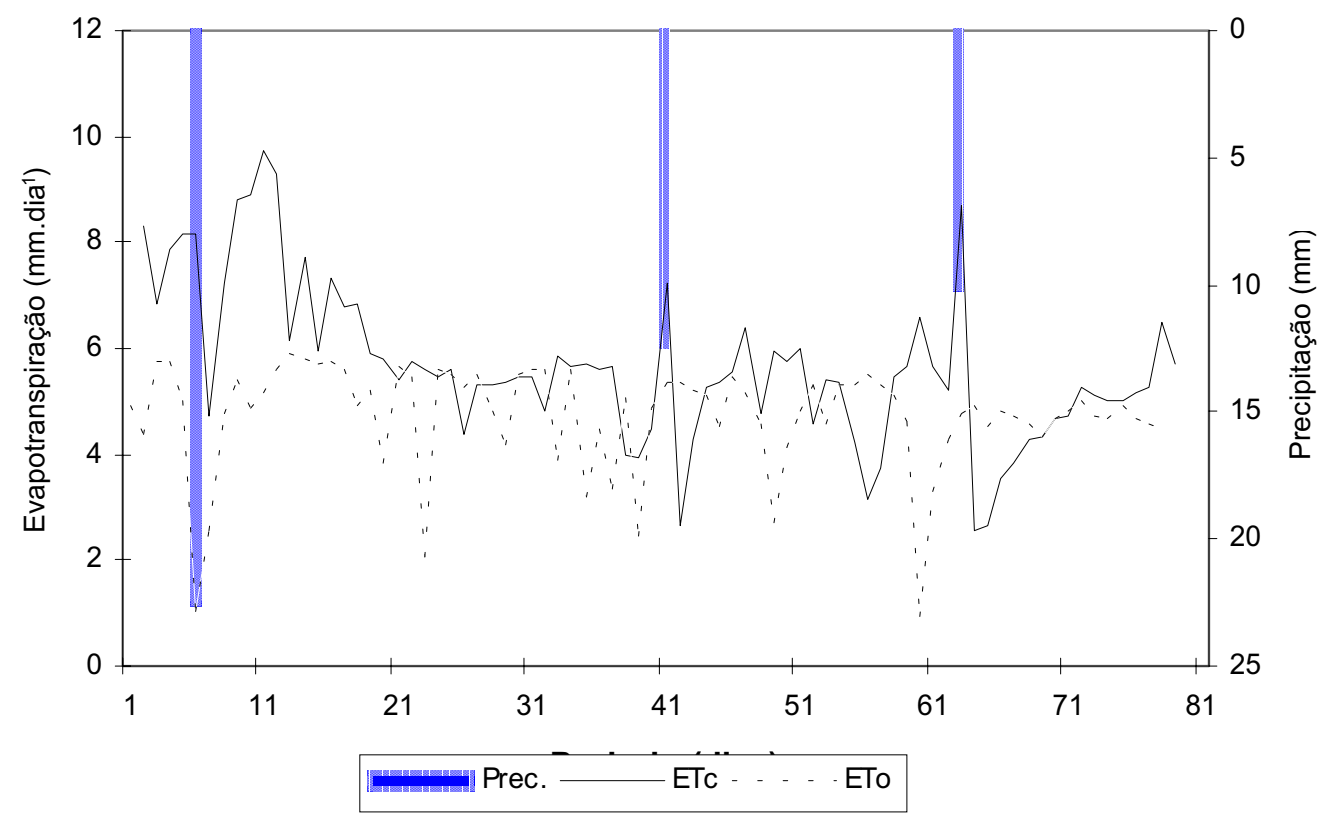

Figura 15 - Consumo de água medida pelos microlisímetros e ETo estimada por Penman-Monteith para o período de 80 dias.

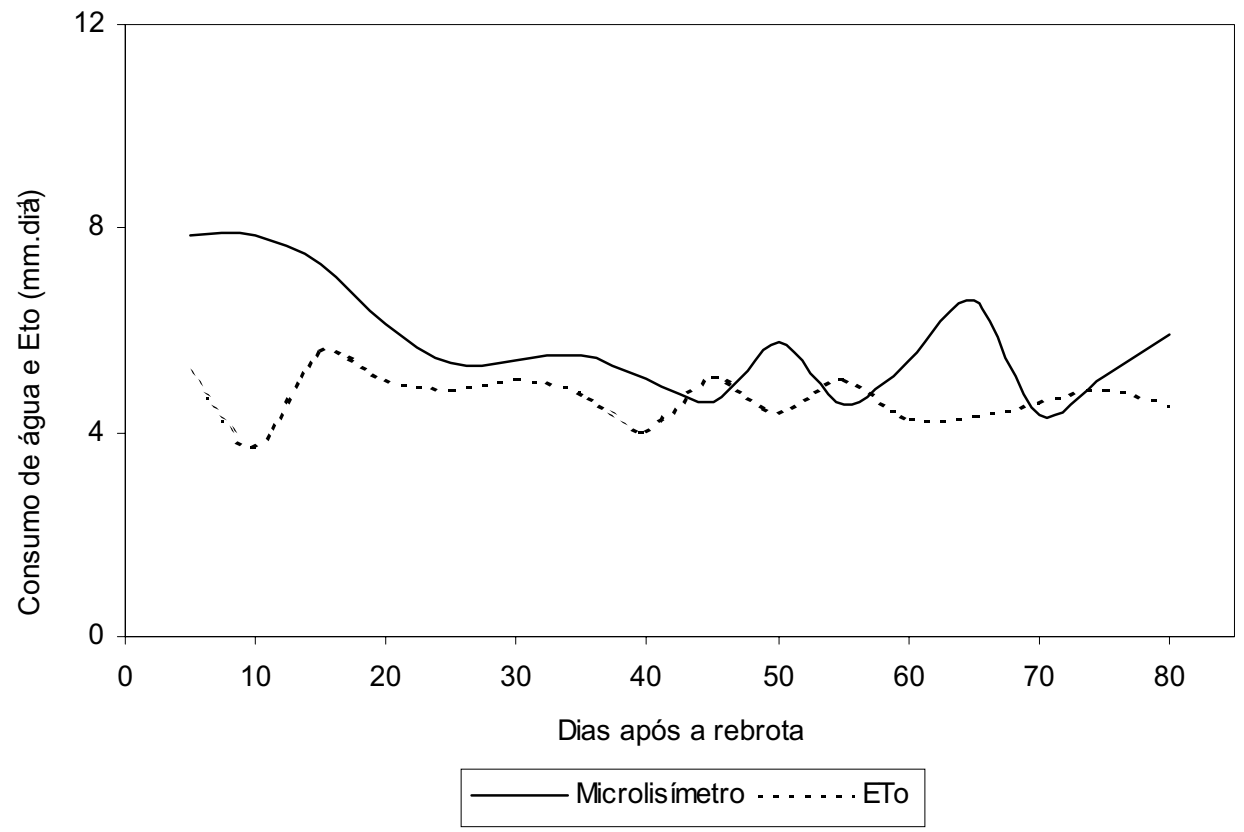

Figura 16 - Consumo de água e ETo médio para o períodos de 5 dias. 
Outro fator a se considerar é a tendência do método Penman-Monteith apresentar uma pequena subestimativa de ETo, em regiões de clima seco. Segundo Sentelhas (1998) este método subestimou a ETo em $10 \%$, durante o período seco, para a região de Piracicaba, SP. Também Smith et al.(1996), utilizando este método para determinar ETo em 11 regiões semi-áridas, encontraram subestimativa nos dados de evapotranspiração. A presente pesquisa foi realizada no período de seca, havendo somente 3 precipitações ao longo do ciclo, ilustradas na Figura 15.

Como exposto anteriormente, os valores de ETc foram elevados na fase inicial da cultura, devido à proximidade do lençol freático com a superfície do solo, favorecendo a evaporação da água. Segundo Tanner \& Jury (1976), a evaporação direta da água do solo é limitada pelas características hidráulicas do solo e seu conteúdo de umidade. Ambas condições existem neste caso, ou seja, elevada umidade com uma tensão de $20 \mathrm{kPa}$ na camada de 0 a $10 \mathrm{~cm}$, no interior dos microlisímetros, e condições que favorecem a condutividade hidráulica devido à composição granulométrica do solo que favorecem as perdas de água por capilaridade, conforme já discutido. Também Soares (1999), estimando a evapotranspiração no período inicial, sob diferentes condições de molhamento do solo, encontrou valores de Kc três vezes maiores quando o solo foi irrigado a cada 4 dias, comparando ao solo em que foi irrigado a cada 7 dias.

Conforme a Figura 17, os valores do coeficiente da cultura $(\mathrm{Kc})$, variaram de 1,45 para os primeiros 25 dias, 1,14 para o período de 26 a 50 dias e de 1,16 para o período de 51 a 80 dias. Para os períodos 2 e 3, os valores estão coerentes com a taxa de crescimento da cultura. Resultados semelhantes para os Kc intermediário e final foram encontrados por Santos et al. (1996), os quais determinariam o coeficiente de cultura da alfafa utilizando o método de Penman e lisímetro de balança para ETo e ETm, respectivamente. Cabe esclarecer que, apesar de serem culturas diferentes, a alfafa e a estévia são plantas perenes e possuem números de cortes e índices de área foliar 


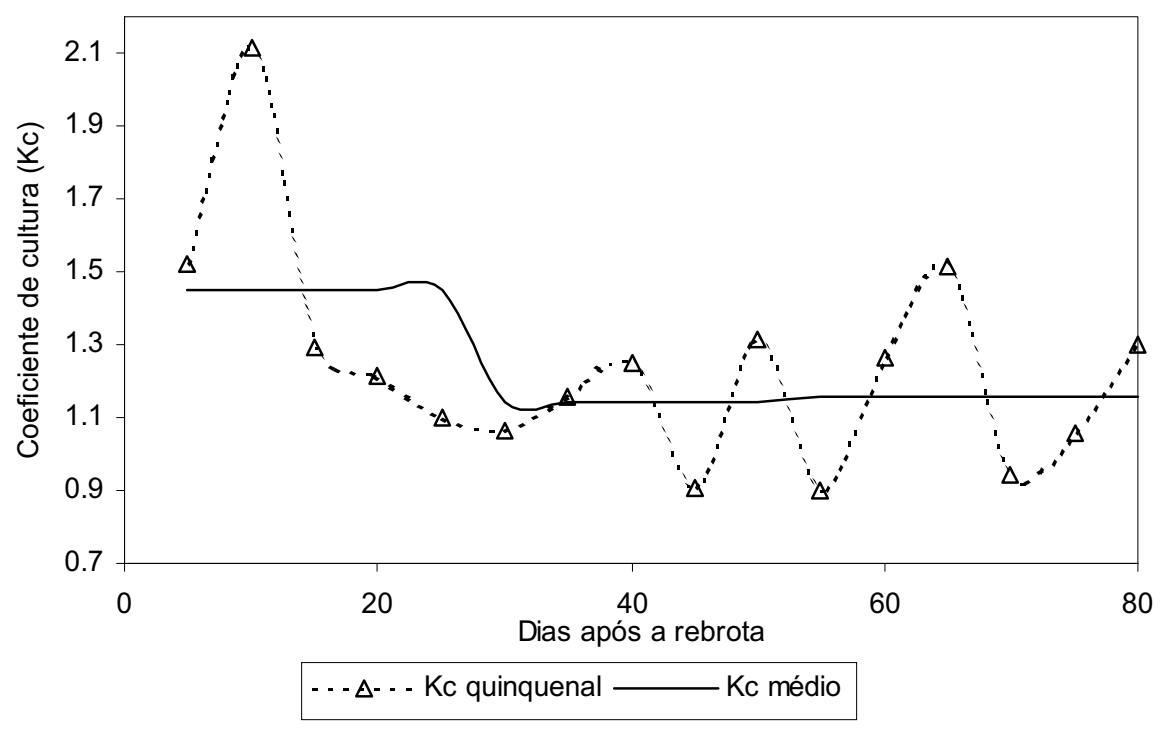

Figura 17 - Variação do coeficiente da cultura $(\mathrm{Kc})$ da estévia ao longo do ciclo.

semelhantes. Os autores evidenciaram que ocorre estabilização do coeficiente após 30 dias do corte. No presente estudo, a cultura da estévia também estabilizou seu Kc entre 1,14 a 1,16 após os 25 dias de corte de uniformização. Esta rápida estabilização, provavelmente, ocorreu devido à localização geográfica de Pisa (latitude $43^{\circ} \mathrm{N}$ ), com 15,3 horas de duração máxima de insolação forte para o mês de junho e energia extraterrestre incidente (Ra) equivalente a $17,3 \mathrm{~mm} \cdot \mathrm{dia}^{-1}$, para o referido mês. Tais condições favorecem a elevada taxa de fotossíntese líquida e o rápido crescimento das plantas.

Doorenbos e Pruitt (1977) encontraram valores de Kc máximo para alfafa, leguminosas herbáceas e gramíneas produtoras de feno de 1,15 para o período que antecede a colheita destas culturas, em regiões de clima seco, valor muito próximo aos encontrados na presente pesquisa.

Os valores médios de $\mathrm{Kc}$ encontrados na presente pesquisa foram bem superiores aos encontrados por González (2000), para a mesma cultura. Este último encontrou valores de Kc para os mesmos períodos de: 0,25; 0,56 e 0,82 , muito abaixo dos valores encontrados no presente trabalho $(1,53 ; 1,14 \mathrm{e}$ $1,16)$, como pode ser observado na Figura 17. A diferença existente pode ser 
explicada pela maior rentabilidade da cultura na presente pesquisa, sendo de $4.369 \mathrm{~kg} \cdot \mathrm{ha}^{-1}$, neste trabalho, e $2.000 \mathrm{~kg} \cdot \mathrm{ha}^{-1}$, no experimento de González (2000) realizado no Paraguai, utilizando o mesmo equipamento. Isto porque a produção de maior área foliar por planta favorece a maior evapotranspiração da cultura, elevando o valor de Kc.

Observa-se que os valores de Kc são elevados quando comparados à maioria das culturas. Tal fato é compreensível, afinal, a cultura, em apenas 80 dias, produziu mais de $4.300 \mathrm{~kg}$ de massa seca foliar por hectare. Esta rentabilidade foi favorecida pelas condições climáticas da região, que favorecem valores elevados de fotossíntese líquida.

\subsection{Resposta da estévia às lâminas de irrigação}

\subsubsection{Efeito das lâminas totais de água sobre o rendimento de folhas}

As diferentes lâminas de irrigação foram aplicadas com base nos dados de evapotranspiração medidos pelos microlisímetros. Os dados foram comparados pela análise da variância (teste $F$ ) e pelo teste de média (teste de Tukey), ambas a $5 \%$ de probabilidade $(P<0,05)$, seguindo o delineamento experimental utilizado (inteiramente casualizado). Utilizou-se o teste de médias porque os dados seguem a distribuição Normal (segundo o Teste de Lilliefors) e os tratamentos apresentam homogeneidade das variâncias (segundo os testes de Cochran e Bartelett). Desta forma, cada lâmina de água foi considerada como um tratamento (variável qualitativa). Caso as diferentes lâminas de água fossem consideradas somente como diferentes níveis (variável quantitativa), o desdobramento dos graus de liberdade desta variável em polinômios ortogonais, para análise de regressão, dificultaria as análises. Portanto, foram realizadas análises tanto quantitativa como qualitativa. $\mathrm{O}$ gráfico de análise da regressão será apresentado para rendimento, número de folhas por planta e índice de área foliar final. 
Conforme apresentado na Tabela 9, observa-se que o rendimento de folhas aumentou com 0 acréscimo das lâminas de irrigação. $A$ análise da variância do rendimento de folhas em função das lâminas de irrigação, evidenciou efeito altamente significativo $(P<0,01)$. Este incremento apresentou uma relação linear significativa, com coeficiente de determinação da ordem de 0,91, conforme apresentado na Figura 18.

Tabela 9. Valores médios de índice de área foliar (aos 25, 50 e 75 dias), numero de folhas por planta (NFP) e rendimento de folhas (Rend), em função das fases da cultura e dos tratamentos irrigados.

\begin{tabular}{|c|c|c|c|c|c|}
\hline Tratamento & IAF inicial & IAF interm. & IAF final & NFP & Rend. (kg.ha $\left.{ }^{-1}\right)$ \\
\hline 117\% ETE & $2,97 a$ & $4,77 \mathrm{a}$ & $7,25 a$ & $4832,5 \mathrm{a}$ & $5130,1 \mathrm{a}$ \\
\hline $100 \%$ ETE & $2,91 \mathrm{a}$ & $4,35 \mathrm{ab}$ & $5,96 a b$ & 4449,6 a & $4931,7 a b$ \\
\hline $80 \%$ ETE & $2,71 \mathrm{a}$ & 3,09 bc & $5,46 \quad b$ & $4478,9 a$ & $4409,7 \quad b$ \\
\hline 64\% ETE & $2,57 \mathrm{a}$ & 2,58 & 3,47 & 3198,9 & 3639,8 \\
\hline 15\% ETE & $2,26 \mathrm{a}$ & 1,91 & 2,80 & 2675,2 & 2405,6 \\
\hline C.V. (\%) & 21,25 & 20,18 & 14,13 & 10,64 & 7,81 \\
\hline
\end{tabular}

Médias seguidas de mesma letra, em cada coluna, não diferem significativamente entre si, a $5 \%$ de probabilidade, pelo teste Tukey.

O menor rendimento de folhas foi verificado para a lâmina de $70 \mathrm{~mm}$ (sem irrigação), evidenciando a importância da irrigação para a região. Entre as lâminas de irrigação, o teste de Tukey evidenciou que, a um nível de $5 \%$ de probabilidade, o rendimento de folhas sem irrigação foi estatisticamente diferente daqueles obtidos com o uso da irrigação (Tabela 9). Para os tratamentos irrigados, observou-se que o tratamento com 117\%ETE (538 mm) não diferiu estatisticamente apenas do tratamento com 100\%ETE (464 mm), o qual, por sua vez, não diferiu de $80 \%$ ETE $(368 \mathrm{~mm}$ ). Já o tratamento com 64\%ETE (295 mm) diferiu de todos os demais. Assim, é possível inferir que o tratamento com 100\%ETE (464 mm) apresentou um desempenho satisfatório 


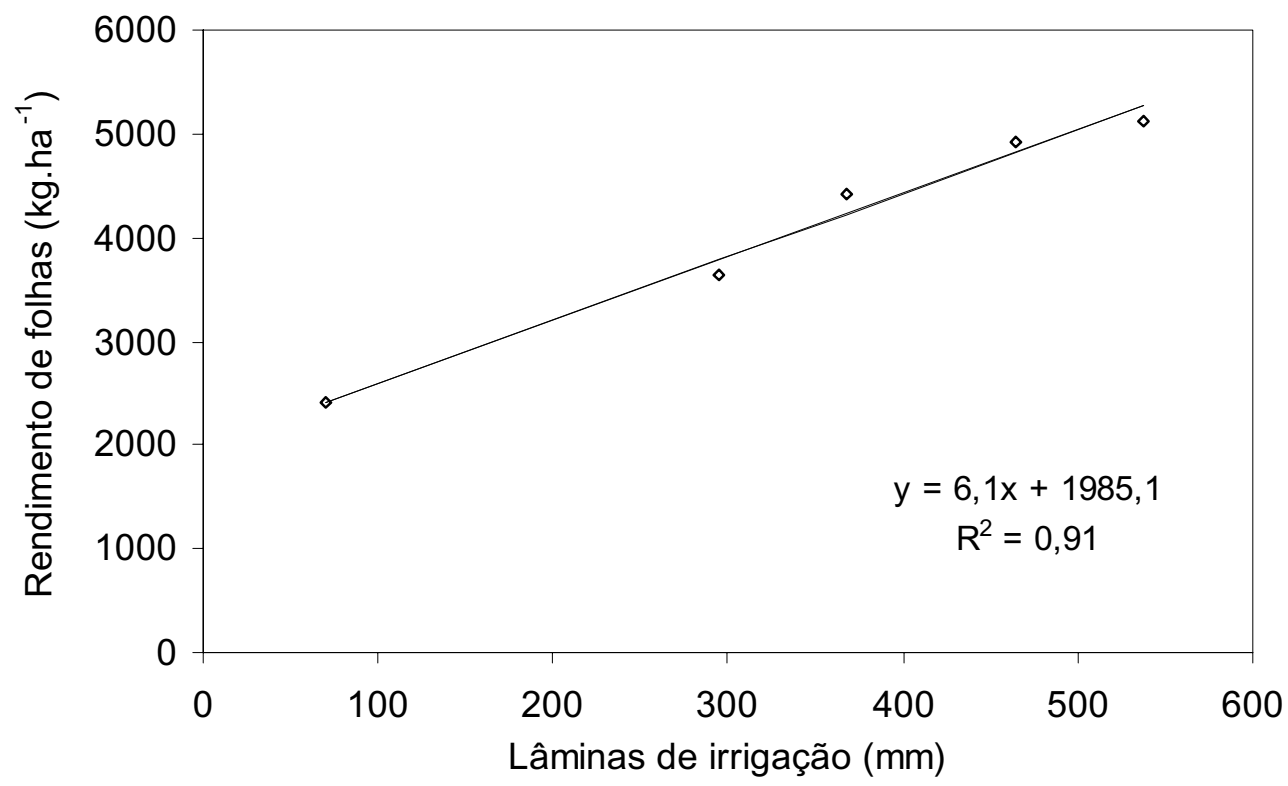

Figura 18 - Rendimento médio de folhas de estévia em função das lâminas totais de água aplicados.

para proporcionar um bom rendimento médio de folhas com um uso racional da água. Caso a Figura 18 fosse tomada como referência de manejo, o tratamento com maior lâmina seria o mais adequado.

Assim, o tratamento com lâmina de irrigação 100\%ETE apresentou rentabilidade $105 \%$ superior ao tratamento sem irrigação, com uma produtividade aumentada em $2.526 \mathrm{~kg} \mathrm{ha}^{-1}$, mostrando ser mais viável, principalmente, em regiões com custo de irrigação elevado.

Os valores de rendimento de folhas encontrados nos tratamentos irrigados com as três maiores doses foram bem superiores aos encontrados por Utumi (1994), que obteve $3.148 \mathrm{~kg} \mathrm{ha}^{-1}$, fornecendo luz artificial e sem limitações de água e nutrientes. Já Lima Filho (1995), obteve rendimento de folhas de apenas $300 \mathrm{~kg} \cdot \mathrm{ha}^{-1}$, testando diferentes condições nutricionais para a cultura.

A expectativa para o presente trabalho era que houvesse estabilização do rendimento quando fossem aplicadas lâminas de irrigação entre 368 e 464 
mm (80\% e 100\%ETE). Afinal, em vários trabalhos realizados na mesma região da presente pesquisa, com cultura anuais e irrigações baseadas na evapotranspiração do mesmo microlisímetro, esta lâmina tem sido o ponto de maior produção (Megale \& Bertolacci, 1999).

As plantas no interior do microlisímetro apresentaram produtividade de $4.369,3 \mathrm{~kg} \cdot \mathrm{ha}^{-1}$, ou seja, um rendimento de folhas $11,4 \%$ menor que o tratamento $100 \% \mathrm{ETE}$. Tudo indica que o menor rendimento foi provocado pela falta de aeração no solo, pois somente a camada superficial (até $10 \mathrm{~cm}$ ), tinha porosidade de aeração superior a 10\%, e $3 \%$ entre 10 e $20 \mathrm{~cm}$ de profundidade.

Segundo Jong van Lier (2001), solos com porosidade de aeração abaixo de $8 \%$, para a camada de $0-10 \mathrm{~cm}$ de profundidade e, $15 \%$ de porosidade de aeração para a camada de 10 a $20 \mathrm{~cm}$ de profundidade do solo, apresentam déficit de oxigênio no sistema radicular. Isto ocorre, pois, abaixo desta porosidade de aeração, reduzem-se as trocas gasosas entre o ar do solo e o atmosférico, havendo falta de $\mathrm{O}_{2}$ disponível para a respiração das raízes e acúmulo de $\mathrm{CO}_{2}$, o qual torna-se tóxico. Este efeito maléfico da deficiência de aeração é aumentado em condições de temperaturas elevadas (Kudrev, 1994).

De acordo com Carlesso (1995), na ausência de $\mathrm{O}_{2}$ no solo, ocorre a diminuição na formação de ATP por mol de açúcar (hexose) utilizado, reduzindo de 36 para somente 2 ATP formados. Ocorre, portanto menor crescimento das plantas devido à diminuição da eficiência de transformação dos fotoassimilados, nestas condições.

Carter \& Floyd (1975) encontraram resultados semelhantes estudando os efeitos da altura do lençol freático sobre a produtividade da cana-de-açúcar plantada em solo franco-argiloso. Os autores constataram queda de produção de $54 \%$ na $3^{a}$ soca, reduzindo-se a altura do lençol freático de $122 \mathrm{~cm}$ para 30 $\mathrm{cm}$ de profundidade.

Ao comparar o rendimento de folhas sob tratamento com maior lâmina de irrigação, 538 mm (117\%ETE), com o obtido nos microlisímetros, observouse um acréscimo de $14,8 \%$ para os primeiros. Isso faz denotar que a deficiência 
de aeração no solo no interior dos equipamentos, causa menor desenvolvimento das plantas, conseqüentemente, subestimando a evapotranspiração nas fases dois e três do ciclo da cultura, onde quem comanda o processo evapotranspirativo é a transpiração, conforme explicado anteriormente.

O maior rendimento nos tratamentos com as diferentes lâminas de irrigação também foi favorecido por capinas semanais, quebrando a crosta superficial, evitando assim perdas por capilaridade. Apesar do menor consumo hídrico, o tratamento irrigado a $80 \% E T E$, alcançou um rendimento de folhas $\left(4.409,7 \mathrm{~kg} \cdot \mathrm{ha}^{-1}\right)$ ligeiramente superior aso $4.369,3 \mathrm{~kg} \cdot \mathrm{ha}^{-1}$ produzidos nos microlisímetros.

\subsubsection{Efeito das lâminas totais de água sobre o índice de área foliar (IAF)}

A avaliação da taxa de crescimento da cultura foi realizada por meio do índice de área foliar em três diferentes fases do ciclo da cultura. $O$ índice de área foliar (IAF) foi determinado por um método não destrutivo. Afinal, a estévia, sendo uma espécie nativa, apresenta alta variabilidade entre plantas. Caso se destruísse as plantas para a determinação do IAF, seria questionável a comparação posterior dos dados coletados nas parcelas, já que estas plantas foram tomadas ao acaso dentro das parcelas.

A evolução dos valores de IAF, durante o período experimental, estão ilustrados na Figura 19. Nos primeiros 25 dias, observa-se que as diferenças entre tratamentos foram pequenas. Após este período, houve um crescimento acentuado do IAF nos dois tratamentos com as maiores lâminas de irrigação.

O tratamento com a maior lâmina de irrigação (117\%ETE), apresentou IAF de 7,25, valor estatisticamente semelhante pelo teste de Tukey aos 5,96 (Tabela 9) do tratamento com 464 mm de lâmina total de irrigação (100\%ETE). Estes valores são considerados altos, mesmo para culturas de elevada 


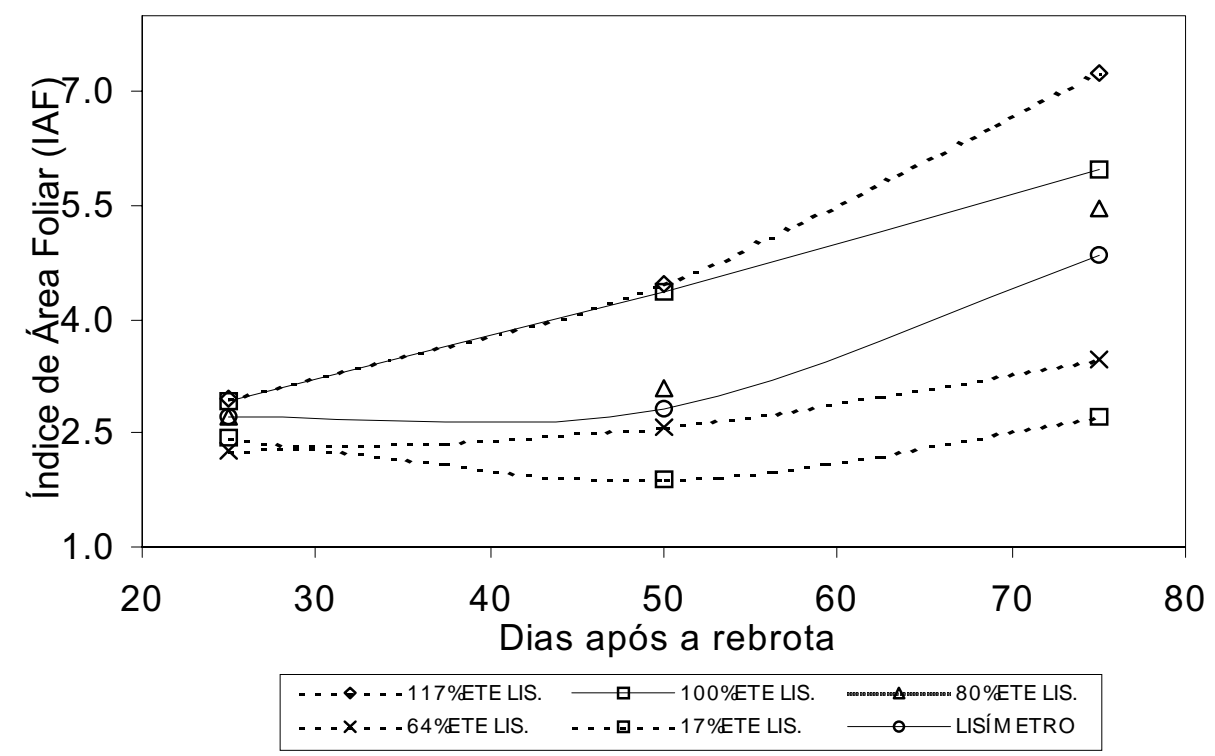

Figura 19 - Índice de Área Foliar nos 5 tratamentos e nos microlisímetros em três fases do cultivo da estévia ( 1 - 25 dias; 2 - 50 dias; 3 - 75 dias).

produção de massa verde. Tais valores foram em média 10 a 20 vezes maiores que os encontrados por Lima Filho e Malavolta (1997). Aos 75 dias o valor de IAF foi 0,35 , cerca de vinte vezes menor que o encontrado no presente trabalho, para a maior lâmina de irrigação. Em seu estudo, o autor utilizou plantas em primeiro ciclo produtivo e atingiu um rendimento de folhas de 3 gramas por planta, ou seja, $300 \mathrm{~kg} \cdot \mathrm{ha}^{-1}$. Esse rendimento foi 17 vezes menor que o encontrado na presente pesquisa.

Valores elevados de IAF também foram encontrados por Welles e Norman (1991) na cultura do soja. Em condições de sombreamento e sob sob sol natural os autores encontraram valores de 6,3 e 5,6, respectivamente. Por sua vez, Bouchet et al. (1963) obtiveram 4,7 para o trigo não irrigado e 5,3 sob irrigação.

Na Figura 20, é ilustrada a correlação entre o rendimento de folhas e o índice de área foliar ( IAF). Apesar das medidas terem sido realizadas com um número diferente de plantas, nota-se que o coeficiente de correlação $\left(r^{2}\right)$ foi 


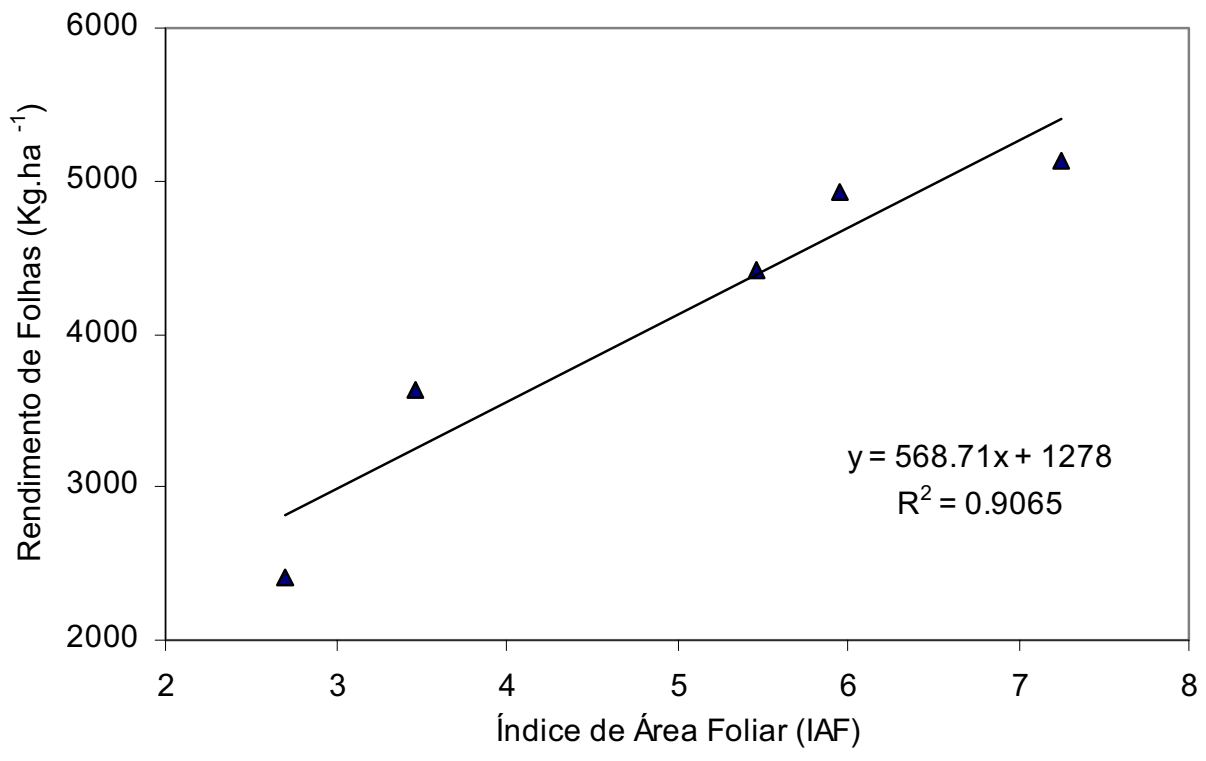

Figura 20 - Correlação entre o índice de área foliar e o rendimento da cultura da estévia.

de 0,91 , indicando boa correlação entre o IAF e a rentabilidade de massa de folhas. Devido a morosidade do método, somente duas plantas por parcela foram utilizadas para a aferição do IAF. Já, para a avaliação do rendimento, foram 10 plantas por parcela.

Pela análise de variância da regressão, observou-se haver significância estatística $(P<0,05)$ entre o rendimento de folhas e o índice de área foliar, indicando relação linear neste nível de significância. Essa relação é esperada, uma vez que o produto comercial da cultura da estévia são suas próprias folhas.

Ainda, o efeito do aumento das lâminas de irrigação no incremento do IAF foi semelhante ao obtido no rendimento de folhas (Figura 21). Este resultado também era esperado, pois, segundo Villa Nova et al. (1996), o IAF é o fator biológico mais importante para o processo de medida da evapotranspiração. Afinal, esse fator representa o tamanho da superfície transpirante e é diretamente proporcional à capacidade produtiva das culturas. 


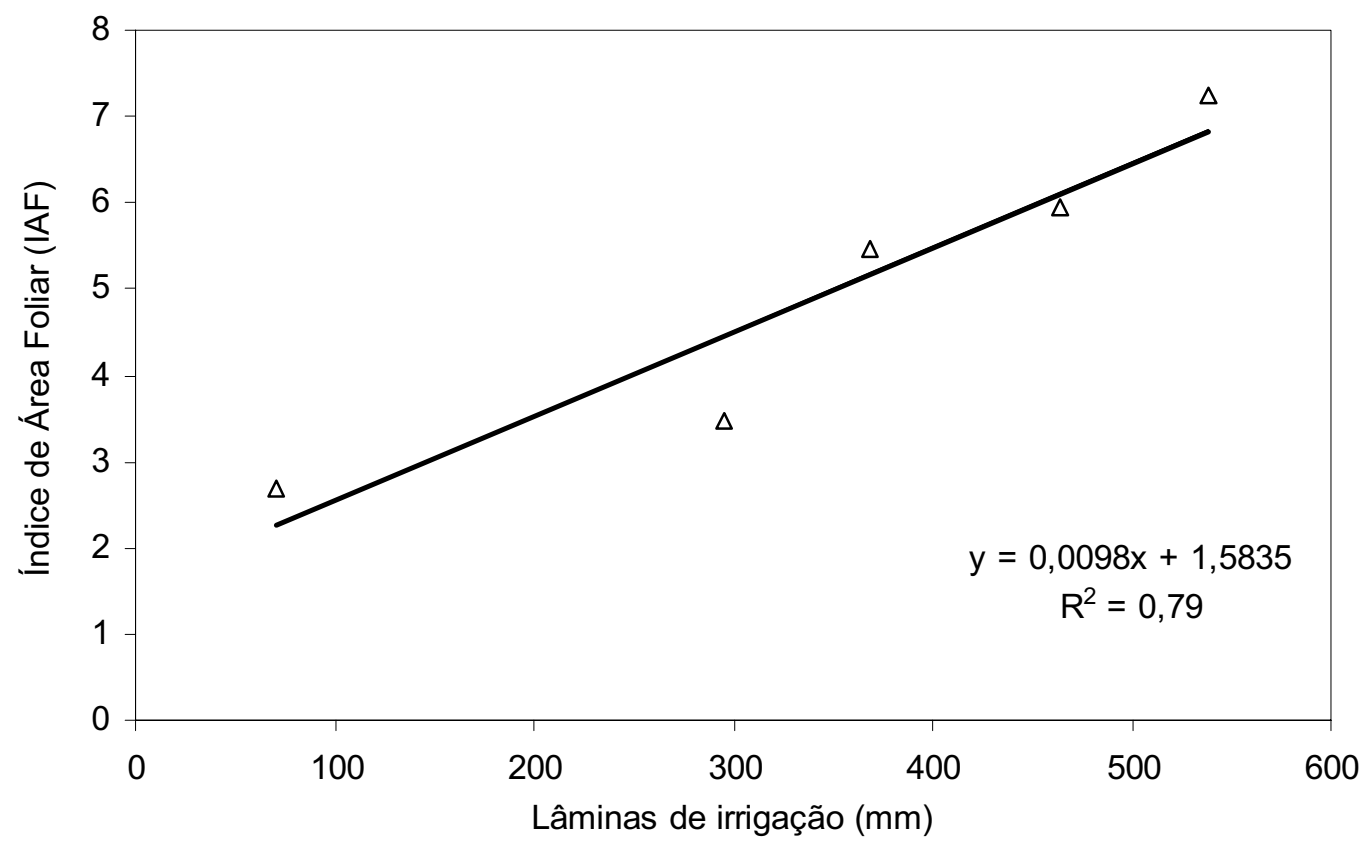

Figura 21 - Índice de área foliar em função das lâminas totais de irrigação.

Aplicando-se a análise de variância da regressão mais uma vez, constatou-se alta significância estatística $(P=0,01)$ entre as lâminas de irrigação e o índice de área foliar, indicando relação linear tanto neste nível de significância como na quadrática a $5 \%$ de probabilidade.

Fica claro, pela Figura 22, a exuberante massa foliar da cultura, onde as plantas atingem aproximadamente 1 metro de altura (altura da cintura). É pertinente esclarecer que não se determinou a altura de plantas nos diversos tratamentos e nos microlisímetros, principalmente, por causa da heterogeneidade, conseqüência da grande variabilidade genética. Cabe ressaltar que as plantas utilizadas eram uma mistura de linhagens nativas e, portanto, não se tratava de uma variedade definida.

Além da altura de plantas, outro parâmetro importante que deixou de ser medido, pelo mesmo motivo, foi a altura de inserção das primeiras folhas. Trata-se de um parâmetro importante para a colheita manual e, principalmente, a mecânica. 


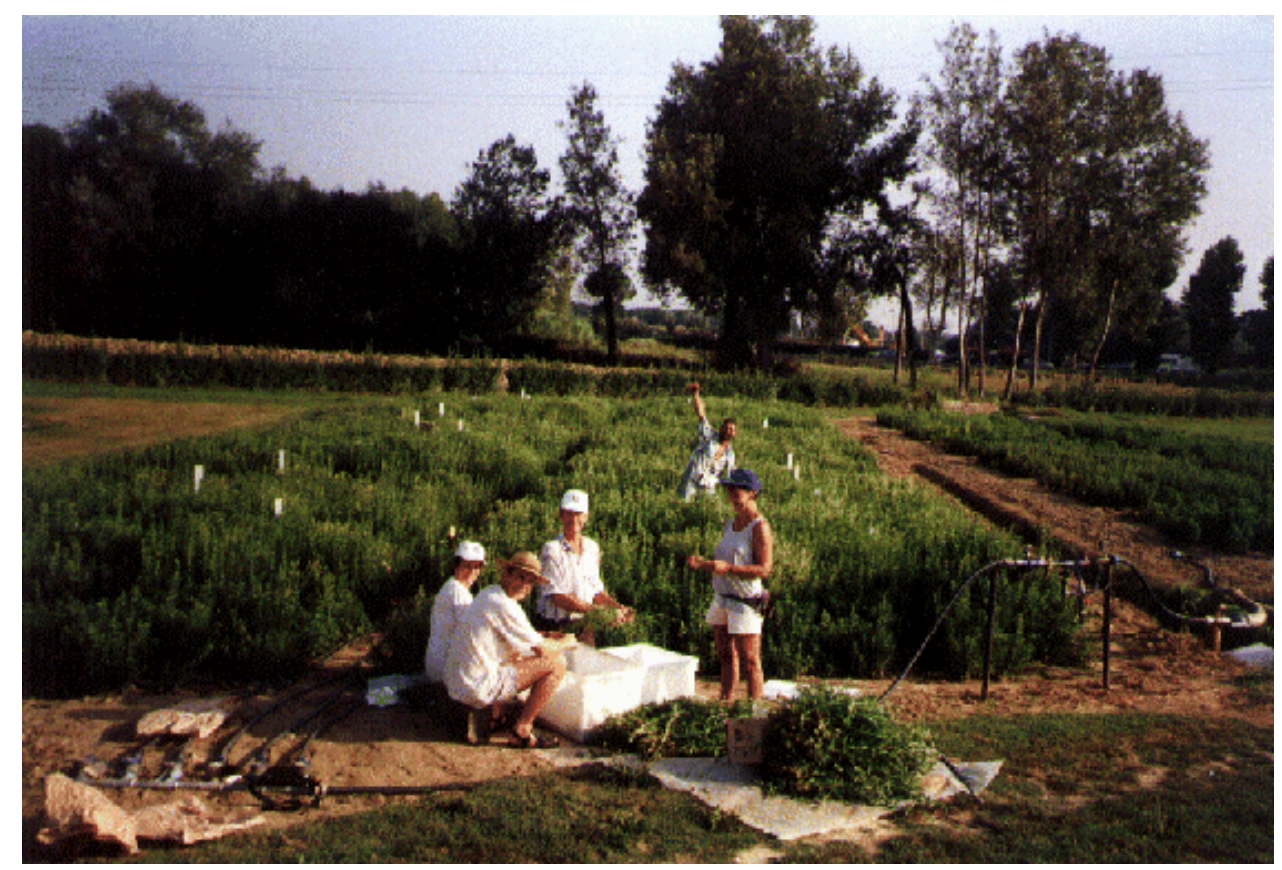

Figura 22 - Visualização da altura das plantas de estévia no momento da colheita e desfolha manual visando a pré-secagem.

Nas condições edafoclimáticas de Assunção - Paraguai, González (2000) obteve valores de altura de planta máxima de 0,68 m em condições ótimas de umidade e nutrientes. Já a altura média em todos os tratamentos foi de $0,50 \mathrm{~m}$.

\subsubsection{Efeito das lâminas totais de água sobre o número de folhas por planta (NFP)}

O efeito das diferentes lâminas de irrigação, visualizado na Figura 23, também foi expressivo no número de folhas por planta (NFP). Quando não se aplicou a irrigação o NFP foi de 2.000 folhas.planta ${ }^{-1}$. Ao passo que no o tratamento com maior nível de irrigação (117\%ETE), foi de 5.000 folhas.planta ${ }^{-1}$.

O número de folhas por planta não apresentou diferença significativa, pelo teste de Tukey, no nível de probabilidade de 5\%, para as três maiores lâminas de irrigação, ficando entre 4.450 a 4.850 folhas por planta (Tabela 9). A 


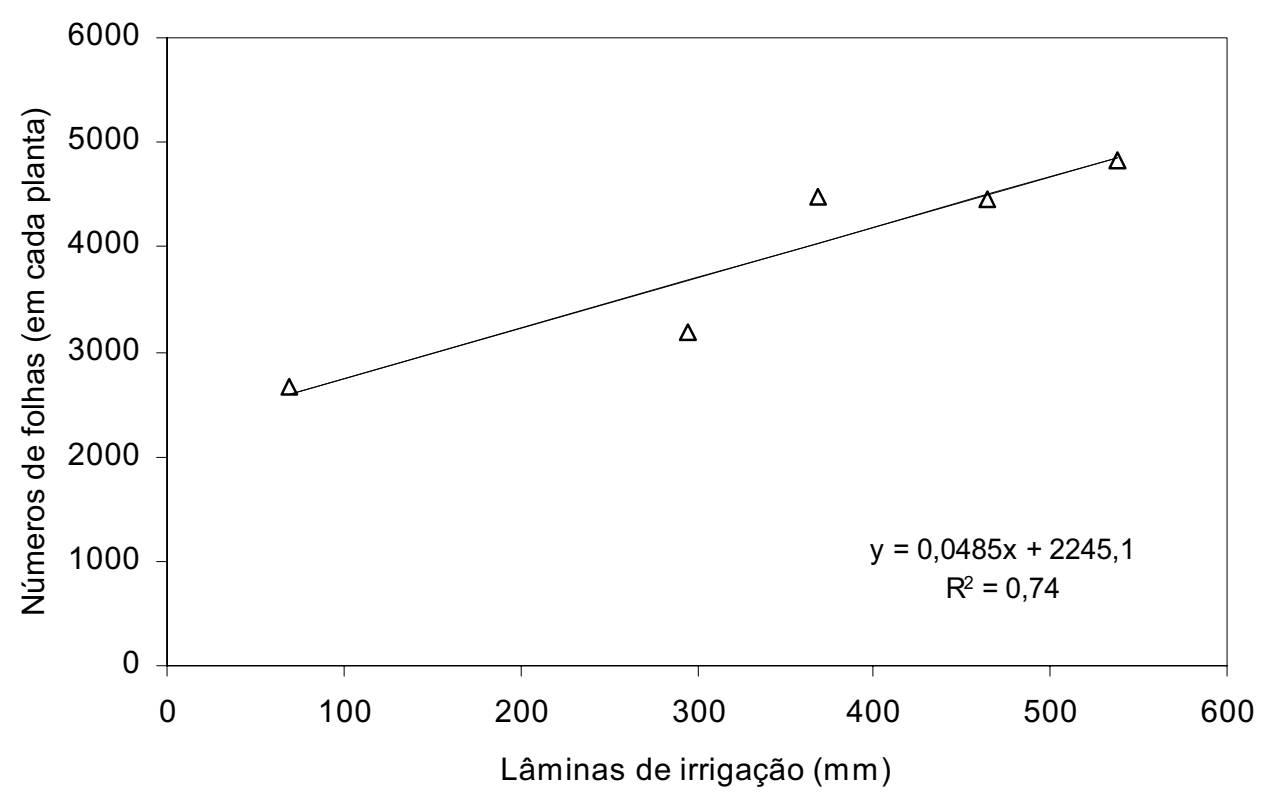

Figura 23 - Equação de correlação entre o número de folhas por planta e lâminas totais de irrigação.

variação do rendimento de matéria seca de folhas esteve mais relacionada ao tamanho das folhas do que ao número de folhas por planta, uma vez que o tratamento com a lâmina de irrigação de $538 \mathrm{~mm}$ não diferiu significativamente da lâmina de $368 \mathrm{~mm}$ para o número de folhas. Por outro lado, houve diferença significativa no rendimento de matéria seca de folhas entre essas duas lâminas de irrigação (Tabela 9).

Pelo gráfico apresentado na Figura 23, verifica-se o incremento linear altamente significativo $(P<0,01)$ do número de folhas por planta com o aumento das lâminas de irrigação.

$\mathrm{Na}$ Figura 24, é ilustrado o incremento do número de folhas por planta, nas diferentes lâminas totais de água aplicadas, durante o período de cultivo. Aos 25 dias, por ocasião da primeira avaliação, o número de folhas é muito semelhante em todos os tratamentos. Afinal, foi efetuado uma irrigação de 25 $\mathrm{mm}$ para todos eles no corte de uniformização. Ademais, ocorreu uma precipitação de $25 \mathrm{~mm} 11$ dias após esta primeira irrigação. 


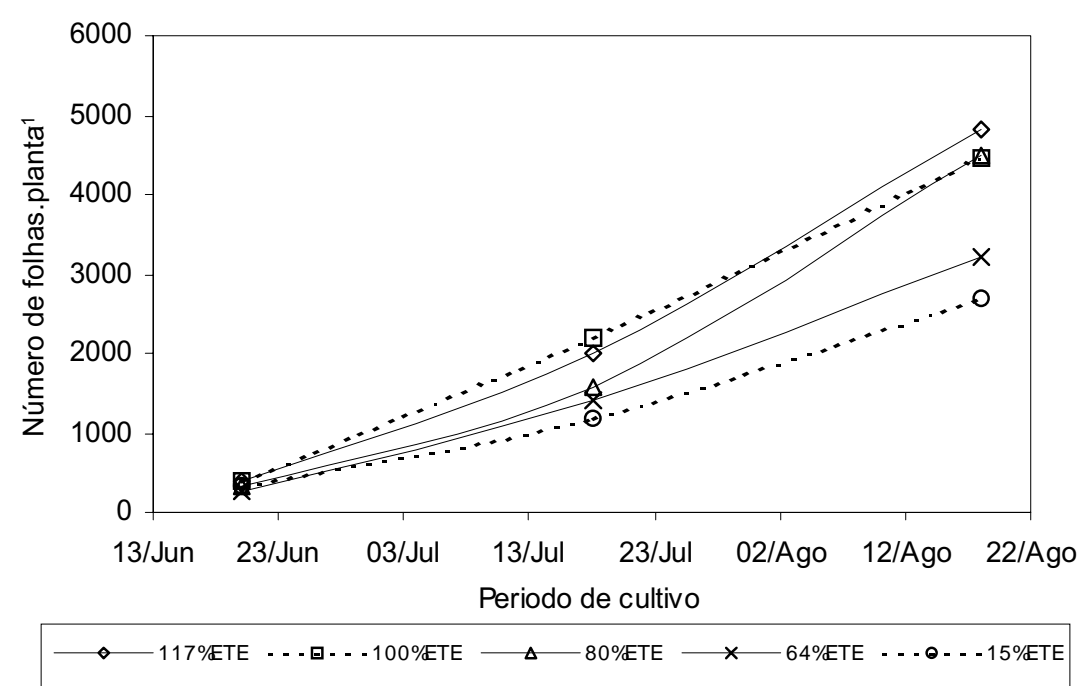

Figura 24 - Efeito das lâminas de irrigação no número de folhas por planta durante o período de cultivo da estévia.

A Tabela 10 mostra que, nos tratamentos irrigados, a eficiência da cultura no uso da água (EUA) variou entre as doses de irrigação. $O$ tratamento com maior déficit (64\% ETE) apresentou $12,34 \mathrm{kgMS} \cdot \mathrm{ha}^{-1} \cdot \mathrm{mm}^{-1}$ e o menor 9,54 $\mathrm{kgMS} \cdot \mathrm{ha}^{-1} \cdot \mathrm{mm}^{-1}$. Como ainda não existiam trabalhos de avaliação da eficiência de uso da água com a cultura da estévia, fez-se um paralelo com outras culturas produtoras de feno ou parte aérea total com valor comercial e com ciclo semelhante. Cunha (1991) trabalhando com a cultura de alfafa, durante o verão, em Eldorado do Sul - RS (latitude $30^{\circ} \mathrm{S}$ ) encontrou valor 9,59 kgMS.ha- ${ }^{-1} \mathrm{~mm}^{-1}$, mantendo o solo a $60 \mathrm{kPa}$. É pertinente sugerir a utilização de maiores lâminas totais de água em trabalhos futuros, visando atingir o ponto de inflexão (rendimento máximo) ou de estabilidade da curva de produção.

A despeito dos valores elevados de rendimento de folhas obtidos no presente estudo existe indicativo que eles poderiam ser mais expressivos. Afinal, o tipo de clima onde foi instalado o experimento é litorâneo, com ventos médios (2-4 m.s $\left.{ }^{-1}\right)$ nas horas mais quentes do dia, fator que pode não ter favorecido a produção. Os ventos podem ter ocasionado um aumento da evaporação nos microlisímetros, principalmente, no período inicial. Para ilustrar 0 efeito dos 
Tabela 10. Produção de massa seca de folhas $\left(\mathrm{MSkg} \cdot \mathrm{ha}{ }^{-1}\right)$, lâmina total de irrigação no ciclo $(\mathrm{mm})$, eficiência do uso da água para produção de folhas $\left(\mathrm{L} . \mathrm{kg}^{-1}\right)$.

\begin{tabular}{|c|c|c|c|c|}
\hline Tratamento & Lâmina (mm) & MS (Kg.ha $\left.{ }^{-1}\right)$ & $\mathrm{Kg} \mathrm{MS} \mathrm{mm}^{-1}$ & L.kgFolha $^{-1}$ \\
\hline Lisímetro & 464 & 4369,29 & 9,50 & 1052,80 \\
\hline 15\%ETE & 70 & 2405,58 & 34,37 & 290,99 \\
\hline $64 \%$ ETE & 295 & 3639,83 & 12,34 & 810,48 \\
\hline $80 \%$ ETE & 368 & 4409,70 & 11,98 & 834,52 \\
\hline 100\%ETE & 464 & 4931,68 & 10,72 & 932,74 \\
\hline 117\%ETE & 538 & 5130,11 & 9,54 & 1048,71 \\
\hline
\end{tabular}

ventos, é possível citar Bouchet et al. (1963). Os autores constataram aumentou em $5 \%$ o consumo hídrico da cultura do trigo, cultivado em região com ventos, redução em $20 \%$ do rendimento de grãos e em $34 \%$ da eficiência de uso da água quando comparado ao experimento irrigado e com quebra-vento.

\subsubsection{Efeito das lâminas totais de água sobre a relação folha/caule}

Os tratamentos com maior lâmina total de irrigação apresentaram menor relação folha/caule (Tabela 11). O tratamento sem irrigação, que recebeu somente $70 \mathrm{~mm}$ de água durante todo o ciclo, apresentou a relação folha/caule $33 \%$ superior aos tratamentos irrigados com $368 \mathrm{~mm}$ e $464 \mathrm{~mm}(80 \%$ e $100 \%$ ETE), diferindo estatisticamente destes dois tratamentos e do $117 \%$ ETE. Resultados semelhantes foram encontrados por Utumi (1994). A autora constatou uma relação de 0,76 para o tratamento sem qualquer deficiência.

Com a redução das lâminas de irrigação, também ocorreu um incremento no teor de matéria seca nas folhas, ou seja, quanto menor a água aplicada para a cultura, menor a quantidade de água em suas folhas. O coeficiente de correlação entre ambas (folha/caule versus \%MSF) foi altamente significativo, com $r^{2}$ de 0,98 . 
Tabela 11. Relações folha/caule e percentagem de matéria seca das folhas (\%MSF), submetida às diferentes lâminas de irrigação.

\begin{tabular}{cccl}
\hline Tratamento & Lâmina $(\mathrm{mm})$ & Folha/Caule & $\%$ Massa Seca Folhas \\
\hline 15\%ETE & 70 & $1,17 \mathrm{a}$ & $25,45 \mathrm{a}$ \\
$64 \% \mathrm{ETE}$ & 295 & $1,05 \mathrm{ab}$ & $23,55 \mathrm{ab}$ \\
$80 \% \mathrm{ETE}$ & 368 & $0,88 \mathrm{bc}$ & $21,03 \mathrm{bc}$ \\
100\%ETE & 464 & $0,88 \mathrm{bc}$ & $20,45 \mathrm{bc}$ \\
117\%ETE & 538 & $0,80 \mathrm{c}$ & $20,15 \mathrm{c}$ \\
Microlisímetro & 464 & 0,95 & 20,10 \\
C.V. (\%) & & 8,68 & 6,79
\end{tabular}

Médias seguidas de mesma letra, em cada coluna, não diferem significativamente entre si, a $5 \%$ de probabilidade, pelo teste Tukey.

\section{4 Água disponível no solo e a produtividade}

\subsubsection{Disponibilidade hídrica nos diferentes tratamentos}

O rendimento relativo da cultura da estévia em função do potencial matricial está apresentado na Figura 25. O rendimento de folhas foi de $78 \%$, quando as plantas foram mantidas sob o potencial matricial da água no solo de $100 \mathrm{kPa}$. Quando o potencial matricial foi mantido a $-200 \mathrm{kPa}$, o rendimento relativo caiu a $50 \%$, indicando que a cultura da estévia apresenta alta sensibilidade ao déficit hídrico. Os efeitos do déficit hídrico foram maiores nos primeiros dias após o corte, uma vez que a estévia, como as culturas produtoras de feno, é exigente em água disponível no solo para esta fase de desenvolvimento (Doorenbos \& Pruitt, 1977; González, 2000).

Os resultados encontrados na presente pesquisa são semelhantes aos determinados por Millar (1976) para a cultura da batatinha. Sob potencial matricial de água no solo de $-100 \mathrm{kPa}$, o rendimento relativo da batatinha é de $78 \%$ e sob potencial de $-150 \mathrm{kPa}$, o rendimento baixou para $70 \%$. Sob mesmo potencial, o rendimento relativo da estévia no presente estudo foi de $68 \%$.

Vale mencionar que a curva de rendimento relativo é importante para a tomada de decisão em projetos de irrigação, pois permite ao agricultor decidir sobre o nível de manejo da irrigação, bem como a metodologia de uso e manejo 
dos dados da relação solo/água/planta/clima para maximizar a produtividade da cultura em condições operacionais (Millar, 1989).

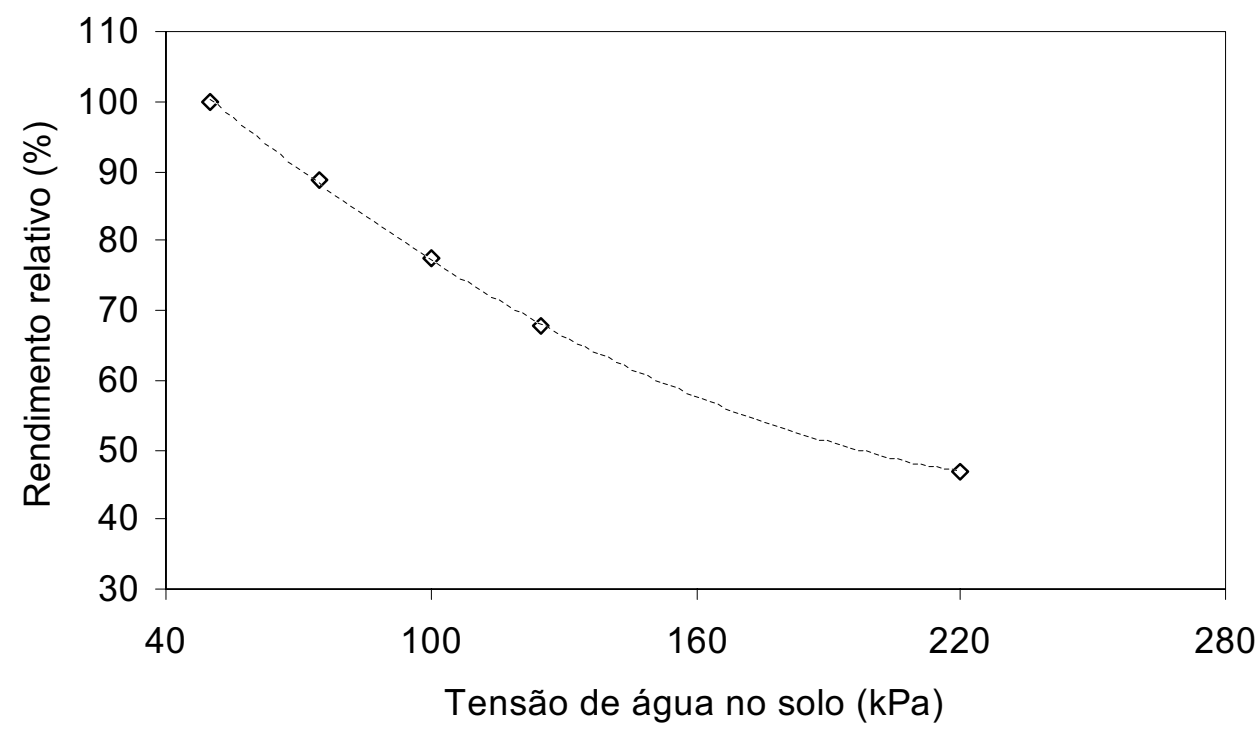

Figura 25 - Rendimento relativo de folhas da estévia em função do potencial matricial da água no solo.

$\mathrm{Na}$ Figura 26 são apresentados os potenciais de água no solo na profundidade de $10 \mathrm{~cm}$. Como era esperado, nas maiores lâminas de água aplicadas, o solo se manteve com maior disponibilidade hídrica e proporcionou melhor produção. Nas parcelas onde foi aplicada a lâmina total de irrigação de $538 \mathrm{~mm}$ (117\%ETE), o solo manteve sob um potencial matricial superior a -50 $\mathrm{kPa}$, para a camada superficial de 0 a $10 \mathrm{~cm}$ de profundidade, região onde se encontra a maior parte do sistema radicular. Essa condição favoreceu o melhor rendimento de folhas.

Os resultados obtidos nesse trabalho divergem um pouco dos encontrados por Bertonha et al. (2000) para as condições de Maringá - PR. Esses pesquisadores, estudando o efeito da disponibilidade hídrica do solo na produtividade de açúcares em folhas de estévia, constataram que sob uma tensão no solo de $117,5 \mathrm{kPa}$ a produção de folhas e o teor de esteviosídeo foram 
maiores. No presente trabalho, a medida que se aumentou a tensão de água no solo, o rendimento de folhas caiu. Tal discrepância pode ser creditada às diferenças das condições edafoclimáticas, afinal, em Maringá, os dias têm menor duração (13,5 horas), devido a latitude mesmo no verão, demanda atmosférica diferente e as condições de aeração do solo podem ser restritivas. Além dos fatores edafoclimáticos, conforme Silveira e Stone (1994), a profundidade de medição e a distância de instalação em relação às plantas são fatores que podem explicar diferenças de valores de tensão crítica de água no solo para uma mesma cultura.

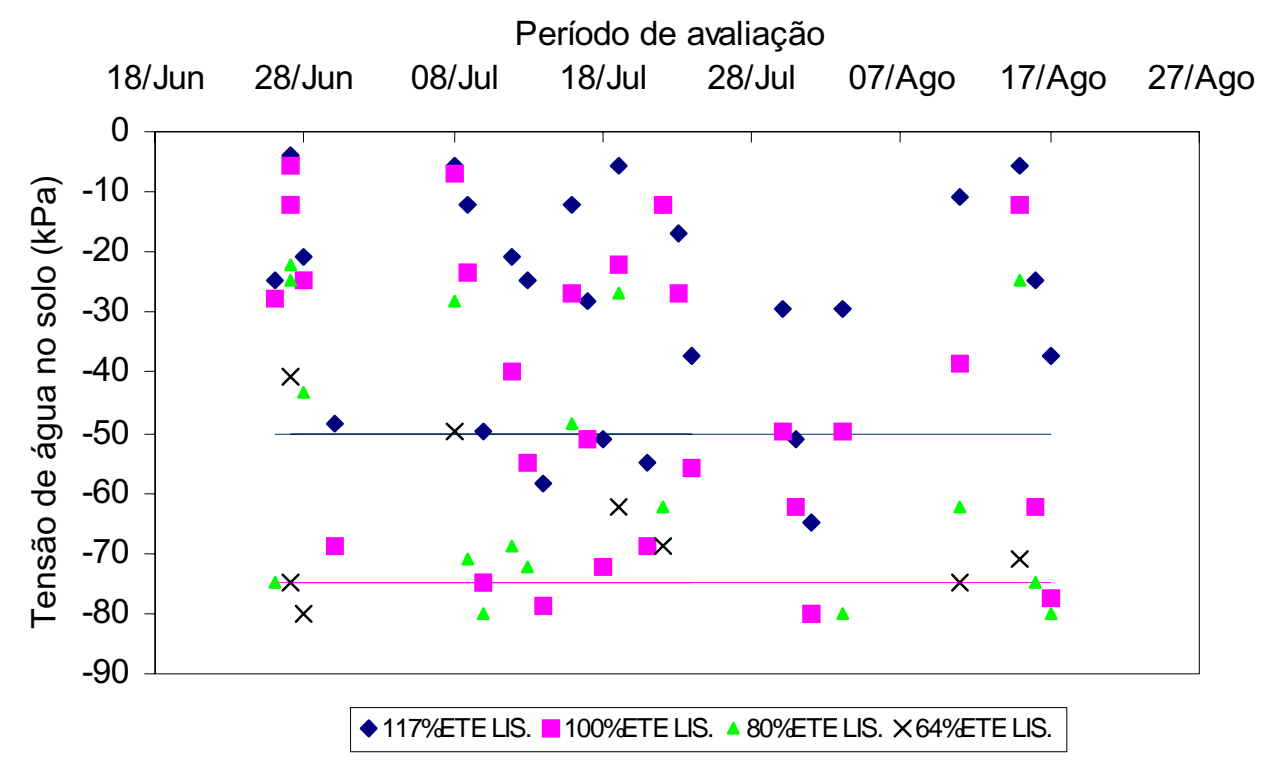

Figura 26 - Variação da tensão de água no solo, medida por tensiômetros a 10 $\mathrm{cm}$ de profundidade.

Na Figura 27 é ilustrado o potencial matricial de água no solo na profundidade de 10 a $20 \mathrm{~cm}$.

Confrontando as figuras 26 e 27 , observa-se que ao se aumentar a profundidade de avaliação, menor é a variação do potencial matricial. Como na camada superficial há uma maior concentração de raízes, bem como está próxima à atmosfera, onde o solo facilmente perde água por capilaridade através 
da evaporação, ocorre maior consumo hídrico e maior variação do potencial matricial. A mesma tendência é notada nas Figuras 28 e 29.

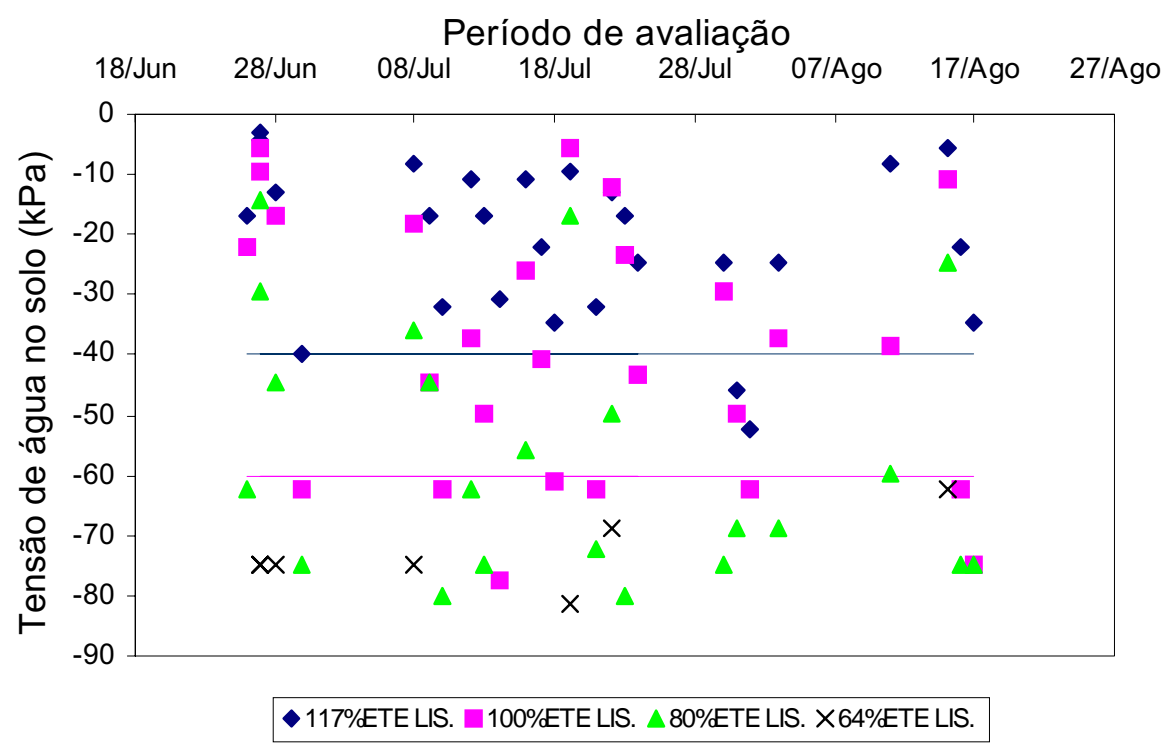

Figura 27 - Variação da tensão de água no solo, medida por tensiômetros a 20 $\mathrm{cm}$ de profundidade.

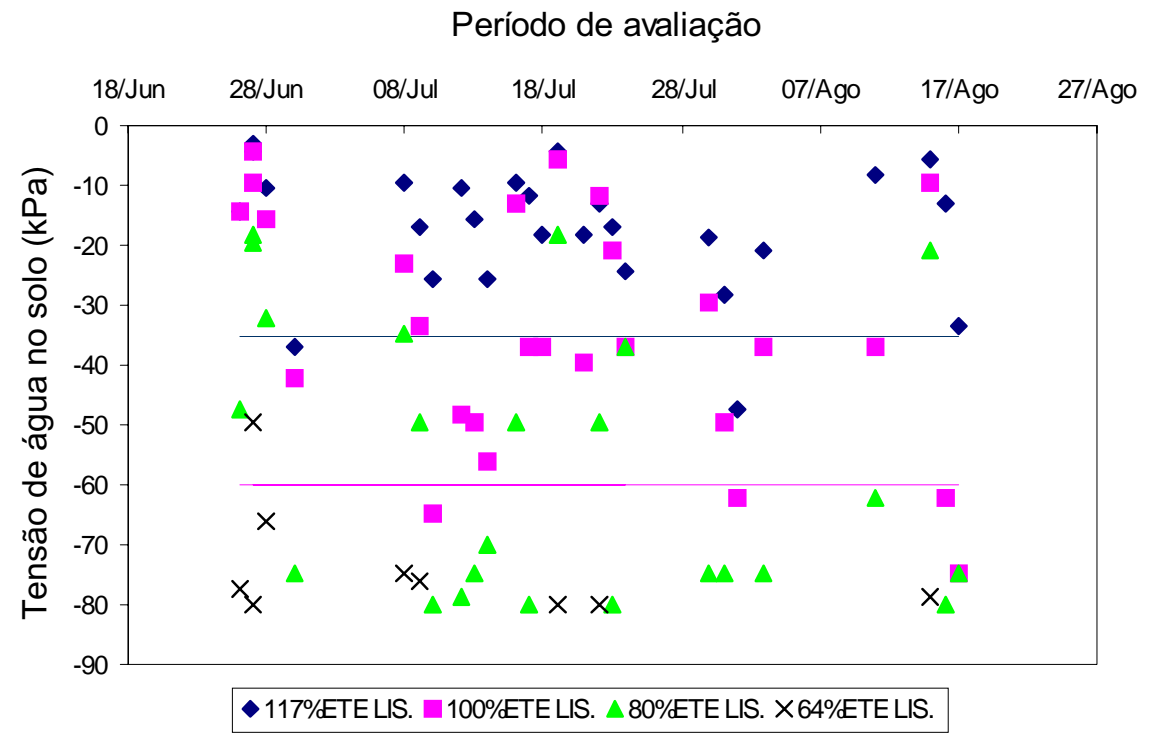

Figura 28 - Variação da tensão de água no solo, medida por tensiômetros a 30 $\mathrm{cm}$ de profundidade. 


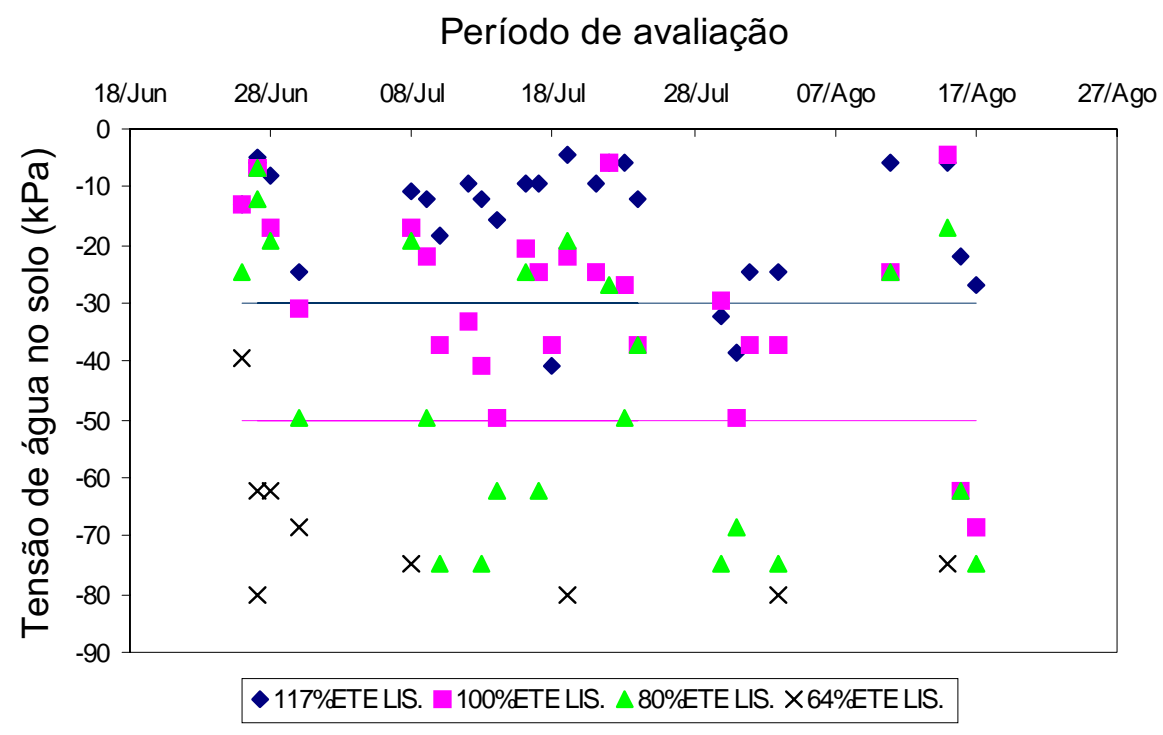

Figura 29 - Variação da tensão de água no solo, medida por tensiômetros a 40 $\mathrm{cm}$ de profundidade.

Analisando-se conjuntamente as Figuras 26 a 29, observa-se que conforme a profundidade de avaliação aumentou, o número de registros nos tratamentos $80 \% \mathrm{ETE}$ e $64 \% \mathrm{ETE}$ foi maior. Afinal, nas camadas mais profundas as perdas hídricas são menores. Nessas condições, o manejo de irrigação via tensiometria de culturas que suportam maior déficit (acima de $80 \mathrm{kPa}$ ) é facilitado. As leituras dos tensiômetros instalados em camadas mais profundas são usadas para estimar os potenciais das camadas mais superficiais. Portanto, nesse tipo de manejo, o controle de irrigação pode ser feito sob potenciais matriciais de água, por exemplo, de $-100 \mathrm{kPa}$ a $-120 \mathrm{kPa}$ nas camadas mais superficiais, de forma segura. Segundo Faria e Costa (1987), a tensão de água medida pelo tensiômetro está diretamente relacionada à facilidade ou dificuldade de absorção de água pelas raízes das plantas. Mediante ao exposto, ressalta-se a importância do irrigante conhecer os valores de água disponível em toda a zona radicular para as aplicações de água.

No tratamento $64 \% E T E$ a flutuação de tensão de água restringiu-se à camada de $0 \mathrm{~cm}$ a $10 \mathrm{~cm}$. Credita-se tal comportamento às pequenas lâminas de 
água aplicadas. Nas demais camadas, o potencial matricial esteve geralmente abaixo de $-80 \mathrm{kPa}$, portanto, os tensiômetros mediam somente por um ou eventualmente dois dias após as irrigações.

\subsubsection{Variação da disponibilidade hídrica e intervalos de irrigação}

A seguir, é descrito o comportamento da disponibilidade hídrica na zona radicular frente os diferentes intervalos de irrigação. As discussões foram feitas com base na maior lâmina (117\%ETE-538mm), devido ao elevado retorno econômico (U\$ 1,00. $\left.\mathrm{kg}^{-1}\right)$ da cultura da estévia.

A Figura 30 mostra que para um dia após as irrigações, as variações da tensão de água no solo foram maiores na camada de $0 \mathrm{~cm}$ a $10 \mathrm{~cm}$. Mais uma vez, a presença da maior parte do sistema radicular nessa camada justifica tal comportamento. Cabe elucidar que após o segundo ano de cultivo, o sistema radicular passa a ser fasciculado, ocupando a camada mais superficial do solo (Bertonha, 1986; Carneiro, 1990).

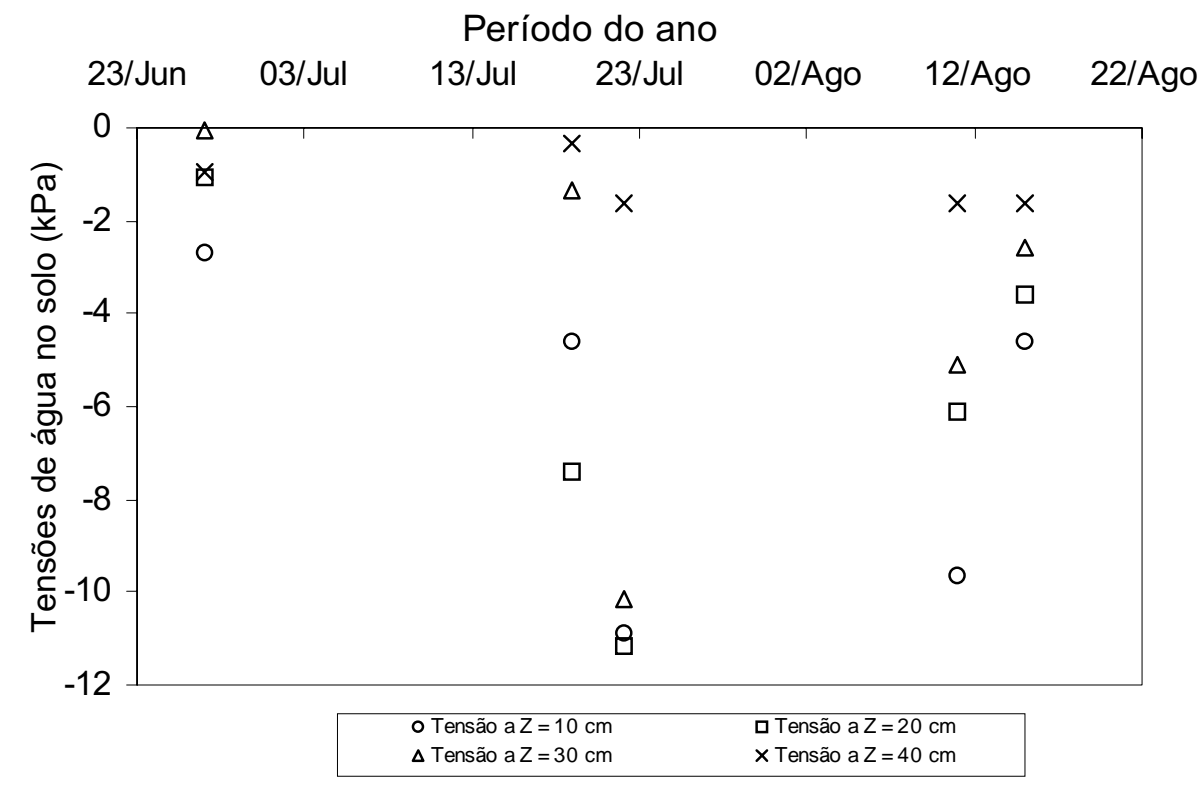

Figura 30 - Tensão de água no solo na zona radicular um dia após as irrigações, na dose de $117 \%$ ETE do microlisímetro. 
Nas primeiras leituras no mês de junho, os potenciais matriciais mantiveram-se muito próximos nas diferentes camadas, ou seja, a transpiração foi pequena. No estágio intermediário da cultura, houve uma tendência dos potenciais se distanciarem nas diferentes camadas, devido à evapotranspiração. Para a profundidade de $40 \mathrm{~cm}$, o teor de água disponível manteve-se estável. A pequena presença de raízes nesta profundidade explica tal fato, pois, conforme Bertonha (1986), o sistema radicular da estévia é de $25 \mathrm{~cm}$.

Dois dias após as irrigações (Figura 31), os potenciais de água no solo foram mais negativos, como conseqüência da evapotranspiração. A diferença mais expressiva constatou-se na camada $40 \mathrm{~cm}$, que acompanhou em menor escala a variação das demais profundidades.

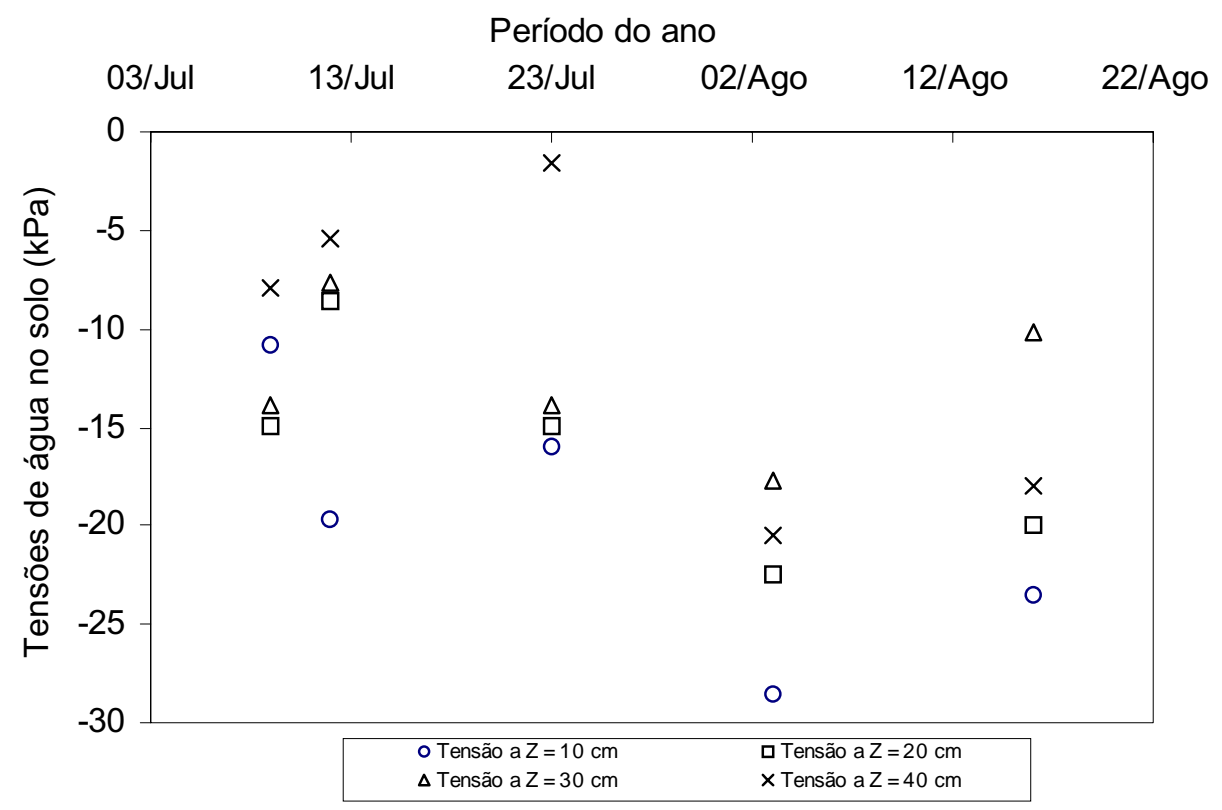

Figura 31 - Tensão de água no solo na zona radicular dois dias após as irrigações, na dose de 117 \% ETE do microlisímetro.

O pequeno gradiente entre a profundidade $40 \mathrm{~cm}$ e $30 \mathrm{~cm}$ foi insuficiente para suplantar o potencial gravitacional já no primeiro dia (Figura 31). 
Pela Figura 32, percebe-se que no intervalo de 3 dias após as irrigações, o potencial matricial atinge valores $-50 \mathrm{kPa}$ na camada de $10 \mathrm{~cm}$ de profundidade. Pelo exposto anteriormente, este é o potencial máximo permitido para se obter o melhor rendimento de folhas. Este parâmetro é importante, pois ao realizar-se um projeto de irrigação é fundamental definir o intervalo das irrigações, parâmetro que interfere no dimensionamento do conjunto motobomba e tubulações do sistema, porém, isto também depende das condições climáticas locais. Além disso, denota-se que os potenciais matriciais apresentaram menor variação ao longo das profundidades.

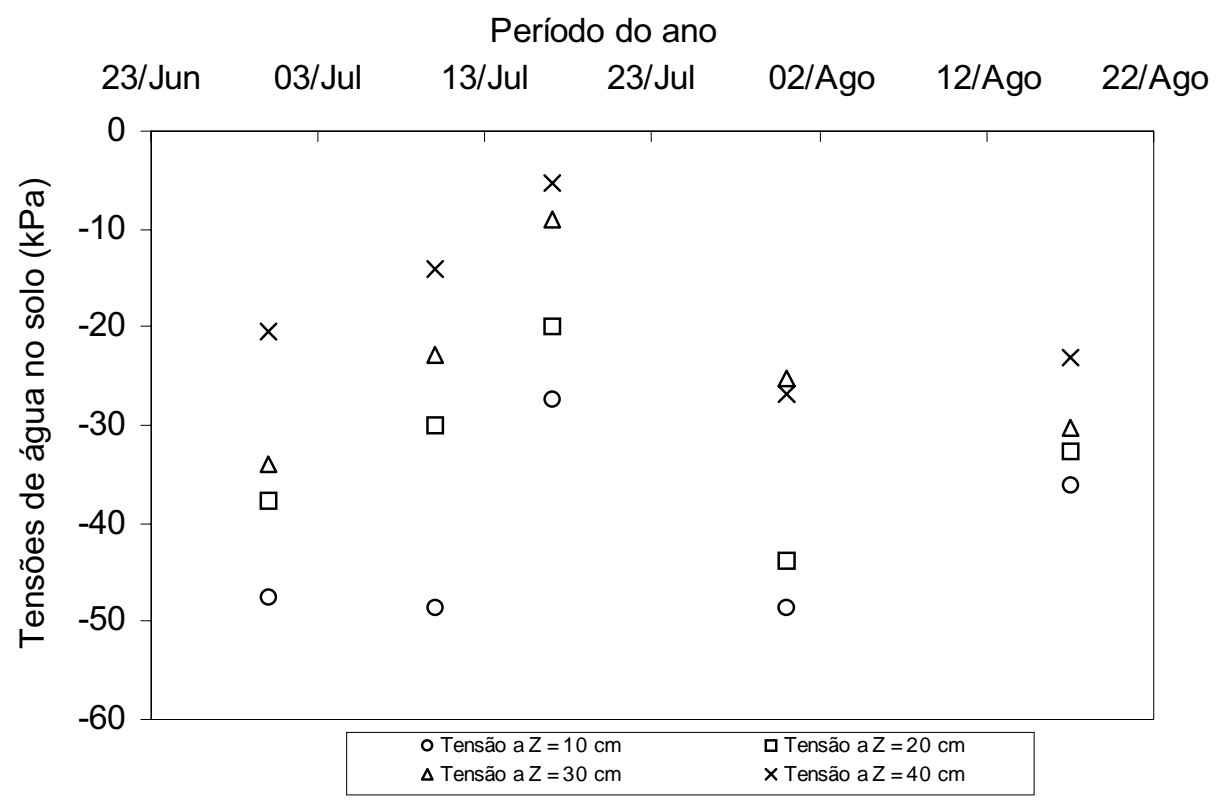

Figura 32 - Tensão de água no solo na zona radicular três dias após as irrigações, na dose de $117 \%$ ETE do microlisímetro.

Apesar de terem sido efetuadas somente quatro irrigações, com 4 dias de intervalo, observa-se, através da Figura 33, que na camada superficial do solo, os potenciais matriciais mantiveram-se abaixo de $-50 \mathrm{kPa}$. Nas demais camadas, os potenciais mantiveram-se acima de $-50 \mathrm{kPa}$ durante todo o período. 


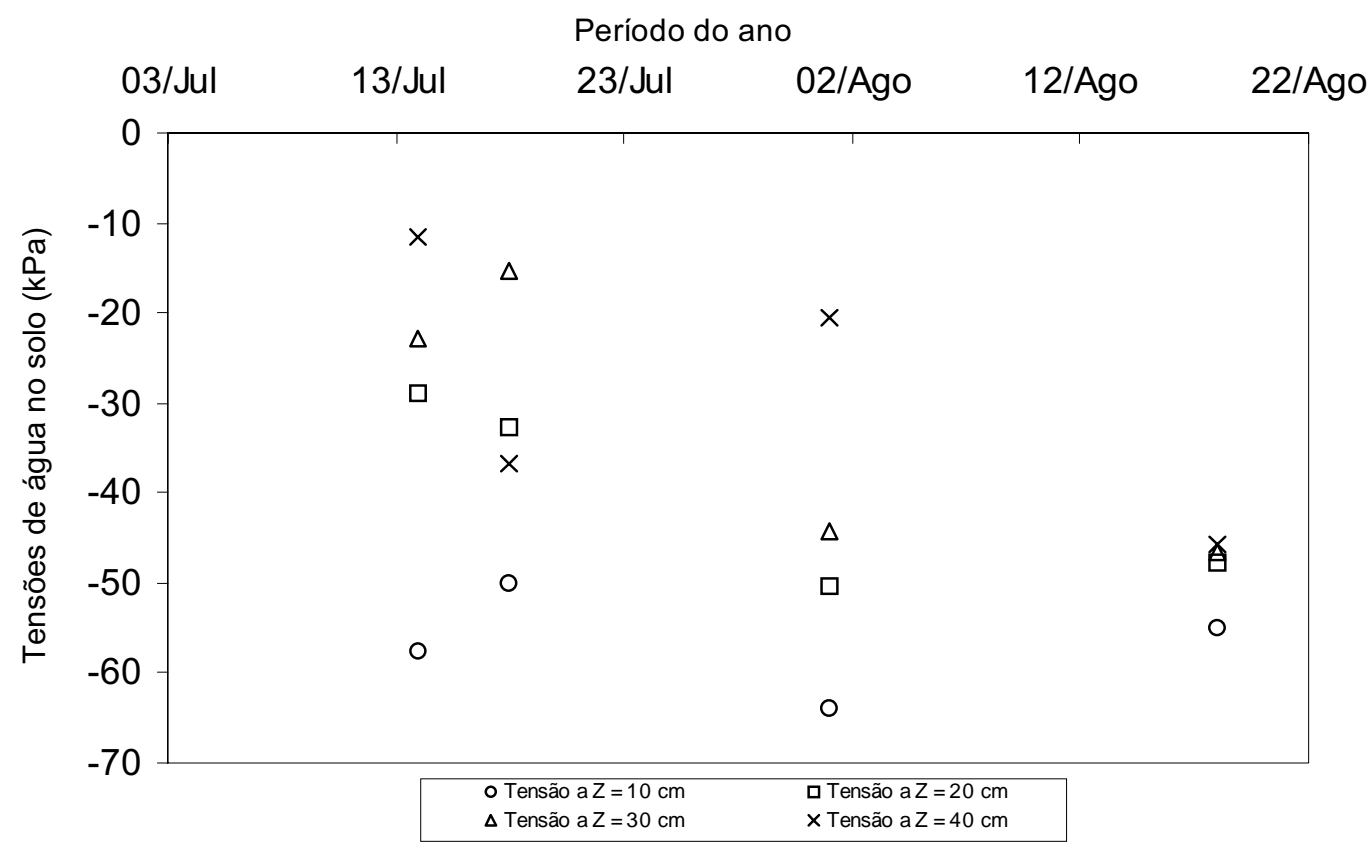

Figura 33 - Tensão de água no solo na zona radicular quatro dias após as irrigações, na dose de $117 \%$ ETE do microlisímetro.

\subsection{Análise de esteviosídeo}

Conforme as análises feitas pelo método HPLC, utilizando padrão: esteviosídeo a $97 \%$, coluna $\mathrm{R}-\mathrm{NH}_{2}$, pode-se observar que não há diferença significativa $(P<0,05)$ entre os tratamentos com relação às diferentes lâminas de irrigação para os três parâmetros. Os resultados estão apresentados na Tabela 12. Os valores de esteviosídeo encontrados nas amostras estão na mesma ordem de grandeza aos apontados por Sakaguchi e Kan (1982) que citam valores de 5 a $15 \%$ de esteviosídeo para a cultura da estévia. Já, os valores aproximados a $2 \%$ do peso seco de rebaudiosídeo $\mathrm{A}$, diferem dos $3 \%$ a $6 \%$ relatados por aqueles autores. O teor de açúcares nas folhas de estévia foi inferior aos encontrados por Bertonha et al. (2000), que foram da ordem de $12 \%$, ou seja, $50 \%$ maiores que na presente pesquisa. Essa diferença pode ser atribuída aos fatores climáticos ou até mesmo ao tipo genético empregado. 
Tabela 12. Análise quantitativa de esteviosídeo, rebaudiosideo $\mathrm{A}$ e rebaudiosideo $\mathrm{C}$ (análise HPLC).

\begin{tabular}{lccc}
\hline Tratamento & Esteviosídeo $(\%)$ & Rebaudiosídeo A(\%) & Rebaudiosídeo C (\%) \\
\hline $117 \%$ ETE & $6,75 \mathrm{a}$ & $1,89 \mathrm{a}$ & $0,20 \mathrm{a}$ \\
$100 \%$ ETE & $4,45 \mathrm{a}$ & $1,45 \mathrm{a}$ & $0,19 \mathrm{a}$ \\
$80 \%$ ETE & $6,68 \mathrm{a}$ & $2,07 \mathrm{a}$ & $0,33 \mathrm{a}$ \\
$64 \%$ ETE & $6,79 \mathrm{a}$ & $1,17 \mathrm{a}$ & $0,28 \mathrm{a}$ \\
$15 \%$ ETE & $7,07 \mathrm{a}$ & $1,72 \mathrm{a}$ & $0,18 \mathrm{a}$ \\
Microlisímetros & $7,22 \mathrm{a}$ & $2,65 \mathrm{a}$ & $0,27 \mathrm{a}$ \\
C.V. $(\%)$ & 11,88 & 36,02 & 52,88
\end{tabular}

Médias seguidas de mesma letra, em cada coluna, não diferem significativamente entre si, a $5 \%$ de probabilidade, pelo teste de Tukey.

O rendimento de açúcares está diretamente relacionado ao rendimento de folhas, uma vez que não há diferença na concentração de açúcares nas folhas em função das lâminas totais de água aplicadas.

\subsection{Avaliação do sistema de irrigação}

Com o intuito de verificar a distribuição de água pelo sistema de irrigação por gotejamento empregado, foram realizadas duas avaliações de uniformidade de aplicação de água, calculando-se o Coeficiente de Uniformidade de Christiansen (CUC).

O coeficiente (CUC) variou de $97,35 \%$, no início do experimento em junho, a 92,13\%, no final do período de irrigações em setembro de 2000 . A aplicação de nutrientes via água de irrigação pouco afetou a uniformidade de distribuição de água nos tratamentos estudados.

\subsection{Rendimento de folhas na segunda colheita}

A segunda colheita da estévia foi realizada em 05 de outubro de 2000, ou seja, 45 dias após a primeira colheita, feita em 20 de agosto do mesmo ano. 
Para este segundo ciclo, fez-se uso da irrigação apenas nos primeiros 10 dias. Posteriormente, começou o período de chuvas na região. A quantificação do rendimento da segunda colheita teve por objetivo verificar a viabilidade ou não de exercê-la. A produtividade média de todos os tratamentos foi de $1050,4 \mathrm{~kg} \cdot \mathrm{ha}^{-1}$. Não houve diferença significativa no rendimento de folhas para as lâminas de irrigação testadas (Tabela 13).

Tabela 13. Rendimento de folhas da cultura da estévia na segunda colheita.

\begin{tabular}{lc}
\hline Tratamento & Rendimento de folhas $\left(\mathrm{kg} \cdot \mathrm{ha}^{-1}\right)$ \\
\hline $117 \%$ ETE & $1086,6 \mathrm{a}$ \\
$100 \% \mathrm{ETE}$ & $1128,1 \mathrm{a}$ \\
$80 \% \mathrm{ETE}$ & $935,5 \mathrm{a}$ \\
$64 \% \mathrm{ETE}$ & $1051,1 \mathrm{a}$ \\
$15 \%$ ETE & $1050,9 \mathrm{a}$ \\
Microlisímetros & 500,2 \\
C.V. $\%)$ & 13,16
\end{tabular}

Médias seguidas de mesma letra, em cada coluna, não diferem significativamente entre si, a 5\% de probabilidade, pelo teste de Tukey.

Foi difícil avaliar o efeito das diferentes lâminas de irrigação devido à ocorrência constante de chuvas fortes na região. As plantas que estavam no interior dos microlisímetros tiveram dificuldade de desenvolvimento, uma vez que o solo permanecia saturado nos dias chuvosos, sem aeração suficiente.

A produtividade média de $1050 \mathrm{~kg} \cdot \mathrm{ha}^{-1}$ é um indicativo da viabilidade de efetivação de uma segunda colheita. Os resultados poderiam ser melhorados recorrendo-se a uma variedade com características específicas, permitindo o rebrote e florescimento uniformes, adiantando a primeira colheita. Efetuando-se a primeira colheita 10 dias antes no mês de agosto, época de alta taxa de fotossíntese, possivelmente haverá incrementar considerável no rendimento de folhas da segunda colheita. 


\subsection{Considerações sobre o desenvolvimento da cultura}

As plantas de estévia começaram a rebrotar no segundo ano de cultivo no final de maio. O rebrote foi desuniforme, possivelmente, devido à inexistência de melhoramento genético da espécie e não haver variedade específica. Este fator foi minimizado com o corte de uniformização feito em 01 de junho de 2000. Imediatamente após esse, fez-se uma adubação e uma irrigação com lâmina de $20 \mathrm{~mm}$, evitando a morte de plantas e induzindo o rápido rebrote.

Houve heterogeneidade na altura de plantas dentro de uma mesma parcela. O mesmo ocorreu para o florescimento, dificultando a escolha do período de colheita, bem como o potencial de rebrota nos diferentes tratamentos. Esta avaliação é importante, pois os cultivos comerciais requerem produção constante, permitindo o ingresso de recursos de forma distribuída para a subsistência do produtor.

O lençol freático da área experimental manteve-se sempre na profundidade de $1,31 \mathrm{~m}$, sendo que o mesmo não interferiu no fornecimento de água por capilaridade nas parcelas experimentais. Isto prejudicaria a avaliação da análise de resposta das lâminas de irrigação sobre os componentes do rendimento de folhas da cultura da estévia.

\subsection{Recomendações para pesquisas futuras}

Em outros experimentos com o microlisímetro descrito, tornam-se fundamental, estudos com diferentes profundidades do lençol freático, em solos de diferente granulometria, em virtude dos efeitos capilares característicos de cada solo. Estes estudos devem ser correlacionados com a profundidade radicular da cultura pesquisada.

Apesar da elevada produtividade da cultura recomenda-se mais estudos com menores freqüências de irrigação e variação nas doses de 
fertilizantes e tipos de fertilizantes, como exemplo o uso de nitrogênio na forma de $\mathrm{NH}_{3}$, substituindo pelo $\mathrm{NH}_{4}{ }^{+}$, pois devido as temperaturas elevadas durante o verão, pois a disponibilidade do elemento é reduzida à cultura, quando fornecida na última formulação (Bar-tal, 2001); ou mesmo fontes diferentes de potássio em locais com presença de níveis críticos de cloro na solução do solo (Zaidan, 1999).

Analisando os resultados obtidos, observou-se que a possibilidade de realizar duas colheitas pode ser viável para a região, pois foram colhidas cerca de 5 ton.ha ${ }^{-1}$ na primeira safra e mais 1 ton. ha ${ }^{-1}$ na segunda colheita. A segunda colheita poderia ser aumentada efetuando-se o corte de uniformização entre $20 \mathrm{e}$ 25 de maio e adiantando-se a primeira safra em alguns dias, 10 a 15 dias. Duas semanas a mais no início de agosto, certamente significaria um importante incremento no rendimento anual da cultura.

É importante o estudo de variedades específicas quanto a resposta a diferentes níveis de irrigação, nutrição mineral, respostas ao fotoperíodo, no rendimento de folhas e esteviosídeo. Outra estudos importantes seriam da mecanização da colheita da estévia, de modo a facilitar os trabalhos executados pelos produtores, resistência das cultivares às doenças, bem como a regionalização de cultivares. 


\section{CONCLUSÕES}

Os resultados obtidos utilizando o microlisímetro de lençol freático constante para estimar a evapotranspiração da cultura da estévia e a resposta das diferentes lâminas de irrigação no rendimento de folhas da cultura, permitiram as seguintes conclusões:

- O uso do microlisímetro de lençol freático constante para a determinação da evapotranspiração da cultura da estévia, superestimou os valores na fase inicial da cultura, ocasionado pela proximidade do lençol freático com a superfície do solo. Os coeficientes de cultura $(\mathrm{Kc})$ foram de 1,45 para os primeiros 25 dias, 1,14 para o período de 26 a 50 dias e de 1,16 para o período de 51 a 80 dias.

- A evapotranspiração da cultura durante a fase de maior desenvolvimento (dos 51 aos 80 dias) foi de $5,44 \mathrm{~mm} \cdot \mathrm{dia}^{-1}$.

- A cultura da estévia apresenta alta resposta de rendimento de folhas ao incremento da lâmina de irrigação. Com um fornecimento de água de irrigação de $538 \mathrm{~mm}$, a produção foi acima de $5.000 \mathrm{~kg} \cdot \mathrm{ha}^{-1}$, indicando a viabilidade técnica de cultivo e do uso da irrigação para estas condições edafoclimáticas.

- A resposta da cultura da estévia, para as doses de irrigação aplicadas, apresentou comportamento linear crescente até a maior dose, de $117 \%$ do 
evapotranspirado no microlisímetro (ETE), com $5.130 \mathrm{~kg} \cdot \mathrm{ha}^{-1}$ em uma única colheita, porém este valor não diferiu estatisticamente da dosagem de $100 \%$ ETE, com rendimento de folhas de $4.932 \mathrm{~kg} \cdot \mathrm{ha}^{-1}$.

- Os tratamentos submetidos a tensão de água no solo de até $50 \mathrm{kPa}$ durante todo o ciclo da cultura apresentaram maior rendimento de folhas, sendo que este decresceu para as tensões maiores.

- A aplicação da irrigação na dosagem de 117\% ETE em intervalos de até 3 dias, demonstrou não afetar o rendimento da cultura da estévia para as condições edafoclimáticas de Pisa, mantendo o potencial matricial superior a $-50 \mathrm{kPa}$.

- O teor de açúcar nas folhas de estévia foi estatisticamente semelhante em todas os tratamentos irrigados, com uma percentagem média de $6,49 \%$ de esteviosídeo, $1,83 \%$ de rebaudeosídeo A e $0,24 \%$ de rebaudeosídeo C.

- A realização da segunda colheita da estévia no mesmo ano propiciou o incremento de $1.050 \mathrm{~kg} \cdot \mathrm{ha}^{-1}$, indicando a viabilidade de sua execução. 


\section{REFERÊNCIAS BIBLIOGRÁFICAS}

ABOUKHALED, A.; ALFARO, A.; SMITH, M. Lysimeters. Rome: FAO, 1982. 68p. (FAO. Irrigation end Drainage, 39).

ALLEN, R.G.; JENSEN, M.E.; WRIGHT, J.L.; BURMAN, R.D. Operation estimates of reference evapotranspiration. Agronomy Journal, v.81, p.650662, 1989.

ALLEN, R.G.; PRUITT.W.O.; JENSEN, M.E. Enviromental requeriments for lysimeter. In: Allen, R.G.; HOWELL,T.A.; PRUITT,W.O.; WATER,I.A.; JENSEN,M.E. Lysimeters for evapotranspiration and enviromental measurements. New York: ASCE, 1991. p.170-181.

ALLEN, R.G.; PEREIRA, L.S.; RAES, D.; SMITH, M. Crop evapotranspiration - guidelines for computing crop water requeriments. Rome: FAO, 1998. 300p. (FAO. Irrigation and Drainage, 56).

ALVAREZ, M. Stevia rebaudiana (Bert.) Bertoni: estado atual do conhecimento. Maringá: Universidade Estadual de Maringá, 1984. 118p.

AMORIM, M. C. de Avaliação da eficácia do lisímetro de lençol freático constante, do tanque classe "A" e do modelo de Penman-Monteith (FAO) para estimativa da evapotranspiração de referência (ETo). Viçosa, 1998, 56p. Dissertação (Mestrado) - Universidade Federal de Viçosa. 
ANDRADE, L.M. Efeitos de diferentes profunidades de lençol freático sobre a produção e os componentes de produção do milho-doce (Zea mays L.). Viçosa, 1991. 53p. Dissertação (Mestrado) - Universidade Federal de Viçosa.

ANGELUCCI, E. Adoçantes e edulcorantes. In: SEMINÁRIO BRASILEIRO SOBRE STEVIA REBAUDIANA (BERT.) BERTONI, 3., Campinas, 1986. Resumos. Campinas: ITAL, 1986. Item 1.

ASSIS, F.N. O uso do evapotranspirômetro no estudo de algumas relações entre evapotranspiração medida e estimada. Piracicaba, 1978. 74p. Dissertação (Mestrado) - Escola Superior de Agricultura "Luiz de Queiroz", Universidade de São Paulo.

AZEVEDO, B.M. Determinação da Evapotranspiração real utilizando lisímetros de drenagem com cultura do milho. Fortaleza, 1993. 38p. Dissertação (Mestrado) - Faculdade de Agronomia - Universidade Federal do Ceará.

AZEVEDO, B.M. Evapotranspiração de referência obtida com a Razão de Bowen, lisímetro de pesagem e equação de Penman-Monteith utilizando sistemas automáticos. Piracicaba, 1999. 81p. Tese (Doutorado) - Escola Superior de Agricultura "Luiz de Queiroz", Universidade de São Paulo.

AZEVEDO, P.V. Coeficiente de cultivo em cultura de tomate irrigado. In: CONGRESSO BRASILEIRO DE AGROMETEOROLOGIA 5., Belém, 1987. Anais. Belém: Sociedade Brasileira de Agrometeorologia, 1987. p.123-125.

BARBIERI, V. Medidas e estimativas de consumo hídrico em cana-de-açúcar. ESALQ/USP. Piracicaba, 1981. 82p. Dissertação (Mestrado) - Escola Superior de Agricultura "Luiz de Queiroz", Universidade de São Paulo. 
BAR-TAL, A. Plant nutrition. Bet-Dagan: Volcani Center/MASHAV, 2001. 24p.

BAVEL, C.H.M. van Lysimeters measurement of evapotranspiration rates in the eastern United States, Soil Science Society of America Proceedings, v.23, n.2, p.138-141, 1961.

BECKER, A.F. Consumo d'água e coeficiente de cultura da alface (Lactuca sativa L) cultivada em Santa Maria. Santa Maria, 1990. 51p. Dissertação (Mestrado) - Centro de Ciências Rurais, Universidade Federal de Santa Maria.

BEGG, J.E.; TURNER, N.C. Crop water deficits. Advances in Agronomy, v.28, p.161-217, 1976.

BERNARDO, S. Manual de irrigação. 6. ed. Viçosa: Imprensa Univ., 1995. $656 \mathrm{p}$.

BeRTOlACCI, M.; MEgALE, P.G. Automazione degli impianti irrigui com microlosimetri. Culture Protette, n.6. p.205-207, 1991.

BERTOLACCI, M.; MEGALE, P.G. Microlisimetri per la stima del fabbisogno irriguo. Pisa: Università di Pisa, Dipartimento di Agronomia e Gestione dell'Agroecosistema, , 1999. 11p.

BERTONHA, A.; MUNIZ, A.S.; CARNEIRO, J.W.P.; MARTINS, E.N.; JABUR, I.C.; THOMAZ, S.I. Estudo de cultivo, reprodução e seleção das variedades mais produtivas de Stevia rebaudiana (BERT) Bertoni, em solos do norte do Paraná. 2. ed. Maringá: UEM, 1984, 103p. (mimeo.). 
BERTONHA, A. Efeito da época de plantio, espaçamento e densidade de plantas na produtividade de Stevia rebaudiana (BERT.) BERTONI. In: SEMINÁRIO BRASILEIRO SOBRE STEVIA REBAUDIANA (BERT.) BERTONI. Campinas, 1986. Resumos. Campinas: ITAL, 1986. p.1-7.

BERTONHA, A.; FRIZZONE, J.A.; PEREIRA, O.C.N. Irrigação e produtividade de açúcares em folhas de stevia (compact disc). In: CONGRESO LATINOAMERICANO DE INGENIERÍA AGRÍCOLA, México, 2000. Anais. México: SLIA, 2000.

BERTONI, M.S. El Ka'a-He'ê (Eupatorium rebaudianum, Species Novas). Revista de Agronomia, v.1, p.35-37, 1899.

BERTONI, M.S. Agenda \& mentor agrícola: guia del agricultor \& colono. 4. ed. Puerto Bertoni: Imprensa y Edicion “EX SYLVIS”", 1927. 512p.

BLACK, T.A.; THURTHELL,G.W.; TANNER,C.B. Hydraulic load lysimeter, construction, calibration and tests. Soil Science, v.32, p.623-629, 1968.

BOUCHET, R.J.; PARCEVAUX, S. de; ARNOUX, J. Amélioration du rendement des végétaux par abaissement de l'évaporatranspiration potentialle. Annuales Agronomiques, v.14, n.5, p.825-834, 1963.

BRANDLE, J.E.; ROSA, N. Heritability for yield, leaft, stem ratio and stevioside content estimated from Landrace Cultivar of Stevia rebaudiana. Canada Journal of Plant Science, v. 72, p.1263-1266, 1998. 
BRASIL. Ministério da Saúde. Divisão Nacional de Vigilância Sanitária de Alimentos. In: ASSOCIAÇÃO BRASILEIRA DAS INDÚSTRIAS DE ALIMENTAÇÃO. Compêndio da legislação de alimentos: consolidação das normas e padrões de alimentos. São Paulo: ABIA, 1991. v.1, cap.3, p.336.

BURMAN, R.D.; NIXON, P.R.; WRIGTH, J.L.; PRUITT, W. Water requeriment. In: JENSEN, M.E. Design and operation of farm irrigation system. St. Joseph: ASAE, 1980. Cap. 6, p.189-232.

CAMARGO, A.P.; SENTELHAS, P.C. Avaliação do desempenho de diferentes métodos de estimativa da evapotranspiração potencial no estado de São Paulo. Revista Brasileira de Agrometeorologia, v.5, n.1, p.89-97, 1997.

CARDELLO, H.M.A.B.; SILVA, M.A.A.P. da; DAMÁSIO, M. H. Análise tempointensidade dos gostos doce e amargo de extrato de folhas de estévia (Stevia rebaudiana Bertoni) em doçura equivalente a sacarose. http://www.scielo.br/cgi-bin (19 maio 2000).

CARLESSO, R. N. Drenagem e aeração do solo. Santa Maria: Universidade Federal de Santa Maria, 1995. 61p. (Série Cadernos Didáticos).

CARNEIRO, J.W.P.; BERTONHA, A.; MARTINS, E.N. Influência da idade da cultura após o corte de uniformização em algumas características agronômicas da Stevia rebaudiana Bertoni. Pesquisa Agropecuária Brasileira, v.24, n.2, p.211-215,1989.

CARNEIRO, J.W.P. Stevia: produção de sementes. Maringá: Universidade Estadual de Maringá, 1990. 65p. 
CARNEIRO, J.W.P.; MUNIZ, A.S.; GUEDES, T.A. Greenhouse bedding plant production of Stevia rebaudiana (Bert.) Bertoni. Canadian Journal of Plant Science, v.77, p.473-474. 1997.

CARTER, C.E.; FLOYD, J.M. Inhibition of sugarcane yields by high water table during dormant season. In: PROCEEDINGS XVI CONGRESS, São Paulo, 1977. Anais. São Paulo: ISSCT, 1077. p.14-18.

CARVALHO, M.A.M. de; ZAIDAN, L.B.P. Obtenção de plantas de Stevia rebaudiana através de estacas. Pesquisa Agropecuária Brasileira, v.30, n.2, p.201-206, fev. 1995.

CIDADE DO DIABÉTICO. Adoçantes. http://www.diabetes.org.br. (21 dez 2001).

CUNHA, G.R. da Evapotranspiração e função de resposta a disponibilidade hídrica em alfafa. Porto Alegre, 1991. 197p. Tese (Doutorado) - Faculdade de Agronomia, Universidade Federal do Rio Grande do Sul.

CURY, D.M.; VILLA NOVA, N.A.A. utilização de um evapotranspirômetro de lençol freático fixo na determinação da demanda de água em hortaliças. Engenharia Agrícola, v.11, p.33-39, 1987.

DOORENBOS, J.; PRUITT, W.O. Crop water requirements. Rome: FAO. 1977. 204p. (FAO. Irrigation and Drainage, 24).

DOORENBOS, J.; KASSAM; A.H. Yeld response to water. Rome: FAO, 1979. 193p. (FAO. Irrigation and Drainage, 33). 
DOORENBOS, J.; PRUITT, W.O. Guidelines for predicting crop water requirementes. Rome: FAO, 1984. 144p. (FAO. Irrigation and Drainage, 24).

ENCARNAÇÃO, C.R.F. Estudo da demanda de água do feijoeiro (Phaseolus vulgaris L.) var. Goiano precoce. Piracicaba, 1980. 62p. Dissertação (Mestrado) - Escola Superior de Agricultura "Luiz de Queiroz", Universidade de São Paulo.

ENCARNAÇÃO, C.R.F.; VILA NOVA, N.A.; ANGELOCCI, L.R. Exigências hídricas e coeficientes culturais da batata (Solanum tuberosum L.). CONGRESSO BRASILEIRO DE.AGROMETEOROLOGIA, 5., Belém, 1987. Anais. Belém: SBA, 1987. p.143-147.

FARIA, R.T. de; COSTA, A.C.S. da Tensiômetro: construção, instalação e utilização. Londrina: IAPAR, 1987. 22p. (IAPAR. Circular, 56).

FELLIPE, G.M.; LUCAS, N.M.C. Estudo da viabilidade dos frutos de Stevia rebaudiana (Bert.) Bertoni. Hoehnea, v.1 p.95-105, 1971.

FELLIPE, G.M. Stevia Rebaudiana Bert.: uma revisao. Ciencia e Cultura, v.29, n.11, p.1240-1248, 1977.

FOLEGATTI, M.V. Avaliação do desempenho de um "Scheduler" na detecção do estresse hídrico em cultura do feijoeiro (Phaseolus vilgaris L.) irrigado com diferentes lâminas. Piracicaba, 1988. 188p. Tese (Doutorado) - Escola Superior de Agricultura "Luiz de Queiroz", Universidade de São Paulo.

FOLEGATTI, M.V. (Coord.) Fertirrigação: citrus, flores, hortaliças. Guaíba: Agropecuária, 1999. 460p. 
FONTES, E.W. da. Evapotranspiração e coeficiente de cultura da couve brócolo (Brassica olerácea var. Itálica) em dois níveis de lençol freático. Botucatu, 1996. 89p. Dissertação (Mestrado) - Faculdades de Ciências Agronômicas, Universidade Estadual Paulista "Júlio de Mesquita Filho".

FREITAS, S. Tire suas dúvidas sobre adoçantes. In: http://www.saudenainternet.com.br. (27 set 2001).

FRIZZONE, J.A. Funções de resposta do feijoeiro (Phaseolus vulgares L.) ao uso de nitrogênio e lâmina de irrigação. Piracicaba, 1986. 133p. Tese (Doutorado) - Escola Superior de Agricultura "Luiz de Queiroz", Universidade de São Paulo.

GONZÀLEZ, R.E. Necesidad de agua para el cultivo de KA'A HE'E (Stevia rebaudiana Bert) bajo riego por goteo, calculado sobre la base de lectura de microlisimetro. San Lorenzo, 2000. 37p. Monografia (Graduacion) Faculdad de Ciencias Agrarias, Universidad Nacional de Asunción.

GROSSI, P.; BERTOLACCI, M.; MEGALE, P.G. Apparecchiatura automatizada per ricerche sperimentali sui rapporti terreno-acqua-pianta. In: GIORNATE TECNICHE DEL PROTAGRI, Pisa. 1990. Anais. Pisa: Instituto de Idraulica Agraria, 1990. p. 240-245.

HANDRO, W.; KERBAUY, G.B. Estabelecimento de culturas e formação de calos em explantes de tecidos de Ocimum mudicale, Sevia rebaudiana e Coffea arabica. Ciencia e Cultura, v.27, p.354-355, 1975.

HANDRO, W.; FERREIRA, C.M. Stevia rebaudiana (Bert.) Bertoni: production of natural sweetners. In: BAJAJ, Y.P.S. (Ed.). Biotechnology in agriculture and foresty. Berlin: Springer-Verlag, 1989. cap.7, p.468-487. 
ISRAELSEN, O.W.; HANSEN, V.E. Irrigation principles and practices. New York: Jonh Willey, 1967. 447p.

JAGTAP, S.S.; JONES, J.W. Stability of crop coefficients under different climatic and irrigation management practices. Irrigation Science, v.10, n.3, p.231-244, 1989.

JONG van LIER, Q. Oxigenação do sistema radicular: uma abordagem física. Revista Brasileira de Ciência do Solo, v.25, n.1 p.233-238, 2001.

KLAR, A.E. A água no sistema solo-planta-atmosfera. São Paulo: Nobel, 1984. 408p.

KLOCKE, N.L.; MARTIN, D.L.; TODD, R.W. Evaporation measurements and predications from soils under crop canopies. Transactions of the ASAE, v.33, n.5, p. 1590-1596, 1990.

KUDREV, T.G. Água: vida das plantas. Trad.: J. G. Resende. São Paulo: Ícone, 1994. 178p.

LEWIS, W.H. Early uses of Stevia rebaudiana (Asteraceae) leaves as a sweetner in Paraguay. Economic Botany, v.46, p.336-337, 1992.

LIBARDI, P.L. Dinâmica da água no solo. Piracicaba: O autor, 1995. 497p.

LIMA FILHO, O.F. de. Distúrbios nutricionais, marchas de absorção de nutrientes, análise do crescimento e teor de esteviosideo em estevia (Stevia rebaudiana Bert.). Piracicaba, 1995. 212p. Tese (Doutorado) - Centro de Energia Nuclear na Agricultura, Universidade de São Paulo. 
LIMA FILHO, O.F. de; MALAVOLTA, E. Estimativa da area foliar em estevia (Stevia rebaudiana Bert. Bertoni). Ciencia e Agrotecnologia, v.21, n.2, p.228-232, 1997.

LIMA FILHO, O.F. de; MALAVOLTA, E.; YABICO, H. Y. Influência de estresses nutricionais no teor e produção de esteiosideo durante o desenvolvimento da estevia. Pesquisa Agropecuaria Brasileira, v.32. n.5 p.485-488, maio, 1997.

LOURENÇO, F.L.; COELHO, R.D.; SORRIA, L.G.; DANTAS NETO, V.; CORSI, M. Coeficiente de cultura $(\mathrm{Kc})$ do capim tanzânia (Panicum maximum Jacq) irrigado por pivô central. In: CONGRESSO BRASILEIRO DE ZOOTECNIA. Piracicaba, 2001. Anais. Piracicaba: SBZ, 1993.

LUNARDI, D.M.C. Efeito da condição de umidade da superfície do solo na evapotranspiração de referência medida e estimada. Botucatu, 2000. 103p. Tese (Livre-Docência) - Faculdades de Ciências Agronômicas, Universidade Estadual Paulista "Júlio de Mesquita Filho".

MAGNANI, G.; BERTOLACCI, M.; OGGIANO, N.; CACCARELLI, E. Ottimizzazione della tecnica irrigua in tunnel coperti com diversi materiali plastici rigidi (PMMA,PVC e PRFV). Colture Protette. v.7. p.25-32. 1990.

MANARA, W.; VEIGA, P.; TARRAGÓ, M.F.S.; MANARA, N.T.F. Estévia -Stevia rebaudiana (Bert.) - aspectos do cultivo no Rio Grande do Sul. Santa Maria: UFSM, Centro de Ciências Rurais,1986. 24p.

MANTOVANI, E.C. Desarrollo y evaluación de modelos para el manejo del riego: estimación da la evapotranspiración y efectos de la uniformidad de aplicación de riego sobre la produción de los cultivos. Córdoba, 1993. 184p. Tese (Doutorado) - Faculdad de Agronomia, Universidad de Cordoba. 
MARTIM DE SANTA OLALLA, F.; De JUAN VALERO, J.A. Agronomia del riego. Madrid: Mundi-Prensa, 1993. 732p.

MATZENAUER, R. Evapotranspiração de plantas cultivadas e coeficiente de cultura. In: BERGAMASCHI, H. Agrometeorologia aplicada a irrigação. 2 ed. Porto Alegre: Ed. UFRGS, 1999. p.33-47.

MEGALE, P.G.; BERTOLACCI,M. Stima dei coefficiente colturali tramite microlisimetri. Pisa: Università di Pisa, Dipartimento di Agronomia e Gestione dell'Agroecosistema, 1999. 10p.

METIVIER, J.; VIANA, A.M. The effect of long and short day lenght upon the growth of whole plants and the level of soluble proteins, suggars, and stevioside in leaves of Stevia rebaudiana Bert. Journal of Experimental Botany, v.30 n.119, p.1211-1222, 1979.

MILLAR, A.A. Respuesta de los cultivos al déficit de agua como información básica para el manejo del riego. Brasília: CODEVASP, FAO, USAID, ABID, 1976. 62p.

MILLAR, A.A. Manejo racional da irrigação: uso de informações básicas sobre diferentes culturas. 2 ed. Brasília: PRONI/IICA, 1989. 57p.

MONTEIRO, R. Estudos taxonômicos em Stevia série Multiaristae no Brasil. Revista Brasileira de Botânca, v.5, n.2, p.5-15, 1982.

MONTEIRO, R. Taxonomia e biologia da reprodução de Stevia rebaudiana (BERT.) BERTONI. Campinas, 1986. 104p. Dissertação (Mestrado) Instituto de Biologia, Universidade Estadual de Campinas. 
MOURA, M.V.T. de; BOTREL, T.A.; FRIZZONE, J.A.; MARQUES JUNIOR, S. Determinação do consumo de água na cultura da cenoura (Dactus carota $\mathrm{L}$ ) através do método lisimétrico. Engenharia Rural, v.4, p.89-101, jul./dez, 1993.

PENMAN, H.L. Evaporation: introduction survey. Netherland Journal of Agricultural Science, v.4, n.1, p.9-29, 1956.

PARDOSSI, A . BERTOLACCI, M.; GEMIGNANI, S.; MEGALE, P.G., TOGNONI, F.; CAMPIONTTI, C.A - L'uso di un microlisimetro per l'automazione dell'irrigazione del melone in coltura protetta. Irrigazione e Drenaggio, v.1, p.14-19,1993

PEREIRA, A.R.; VILLA NOVA, N.A.; SEDIYAMA, G.C. Evapo(transpi)ração. Piracicaba: FEALQ, 1997. 183 p.

PEREIRA, L.S.; ALLEN, R.G. Novas aproximações aos coeficientes culturais. Piracicaba. Engenharia Agrícola, v.16, n.4, p.118-143, 1997.

PEREIRA, F.A.C. Efeitos de diferentes profundidades do lençol freático sobre a evapotranspiração, o coeficiente de cultura, a produção e os componentes de produção da alface (Lactuca sativa L.). Viçosa, 1994. 55p. Dissertação (Mestrado) - Universidade Federal de Viçosa.

PEREIRA, F.A.C. Desempenho do modelo de Penman-Monteith e de dois evaporímetros na estimativa da evapotranspiração de referência $\left(E T_{0}\right)$ em relação a um lisímetro de pesagem. Piracicaba, 1998. 87p. Tese (Doutorado) - Escola Superior de Agricultura "Luiz de Queiroz", Universidade de São Paulo. 
PEREIRA, L.S.; PERRIER, A.; RICHARD, G.A.; ALVES, I. Evapotranspiration: Concepts and Future Trends. Journal of Irrigation end Drainage Engineering ASCE, v.125, n.2, p.45-51, Mar./Apr. 1999.

PERES, J.G.; SCARDUA, R.; VILLA NOVA, N.A. Coeficiente de cultura (Kc) para cana-de-açucar: ciclo de cana-soca. Alcool \& Açúcar, n.62, p34-42. 1992.

PERES, J.G.; PEREIRA, A.R.; FRIZZONE, J.A. Avaliação do modelo de Penman-Monteith para estimativa da evapotranspiração de referência padronizada pela FAO. Engenharia Rural, v.6, n.1, p.65-75, 1995.

PRUITT. W.O. Development of crop coefficients using lysimeters. In: ALLEN, R.G.; HOWELL, T.A.; PRUITT, W.O.; WATER, I.A.; JENSEN, M.E. Lysimeters for evapotranspiration and enviromental measurements. New York: ASCE, 1991. p.182-190.

PRUITT, W.O.; ANGUS, D.E. Large weighting for measuring evapotranspiration. Transactions of the ASAE, v.3, n.2, p.13-18, 1960.

PRUITT, W.O.; JENSEN, M.C. Determining when to irrigated. Agricultural Engeneering, v.36, p.389-393, 1955.

PRUITT, W.O.; OETTINGEN, S. von; MORGAN, D.L. Central California evapotranspiration frequences. ASCE Irrigation and Drainage, v.98, p.177184, 1972,

RANDI, A.M.; FELLIPE, G.M. Efeito da temperatura, luz e reguladores de crescimento na germinação de Stevia rebaudiana BERT. Ciência e Cultura, v. 33, n.3, p.404-411, 1981. 
REICHARDT, K. Dinâmica da matéria e da energia em ecossistemas. 2. ed. Piracicaba: ESALQ, Depto. de Física e Meteorologia, 1996. 513p.

REIS, E.F. Efeitos de quatro profundidades freáticas sobre o uso consultivo e o crescimento da alface (Lactuca satival L.). Viçosa, 1991. 53p. Dissertação (Mestrado) - Universidade Federal de Viçosa.

RICHIE, J.T.; BURNETT, E.A. A precision weighing lysimeters for row crop water use studies. Agronomy Journal, v.60, p. 545-549, 1968.

RISALITI, R.; MACHIA, M.; ANGELINI, L. Stevia rebaudiana Bertoni, aspetti biologici e tecnica colturale. Pisa: Università di Pisa, Scuola di Specializzazione in Scienza e tecnica delle Piante Officinali, Facoltà di Farmacia, 1997. 23p.

ROCHA, R.F.; VALIO, I.F.M. Nota prévia sobre floração em Stevia rebaudiana Bert. Ciencia e Cultura. v.24, p.331, 1972. (Suplemento).

ROSENBERG, N.J. Microclimate: the the biological environment. New York: John Wiley, 1974. 315p.

SAAD, J.C.C.; SCALLOPI, E.J. Análise dos principais métodos climatológicos para estimativa da evapotranspiração. In: CONGRESSO NACIONAL DE IRRIGAÇÃO E DRENAGEM, 8., Florianópolis, 1988. Anais. Florianópolis: ABID, 1988. p.999-1021.

SAKAGUCHI, M.; KAN, T. As pequisas japonesas com Stevia rebaudiana (Bert.) Bertoni e o esteviosídeo. Ciencia e Cultura, v.34, n.2, p.235-248, 1982. 
SANTOS, A.O.; BERGAMASCHI, H.; CUNHA, G.R. Necessidades hídricas da alfafa: Coeficiente de cultura $(\mathrm{Kc})$ no período pós corte. Revista Brasileira de Agrometeorologia, v.4, n.1. p.37-40, 1996.

SANTOS, G.A.S. Evapotranspiração e coeficiente de tanque $(\mathrm{kp})$ e da cultura $(\mathrm{kc})$ do melão (Cucunis melo L.). ITEM. Irrigação e Tecnologia Moderna, v.34, p.32-39, set. 1988.

SCALOPPI, J.E. Métodos climatológicos para avaliar a evapotranspiração. Piracicaba, 1972. 80p. Dissertação (Mestrado) - Escola Superior de Agricultura "Luiz de Queiroz", Universidade de São Paulo.

SEDIYAMA, G.C. A versão/proposta para o conceito de evapotranspiração de referência. Campina Grande: Sociedade Brasileira de Agrometeorologia, 1995. 14p.

SEDIYAMA, G.C. Evapotranspiração: necessidade de água para as plantas cultivadas. Brasília: ABEAS, 1996. 173p. (Curso por tutoria à distância).

SEDIYAMA, G.C. Estimativa da evapotranspiração: histórico, evolução e análise crítica. Revista Brasileira de Agrometeorologia, v.4. n.1, p.1-12, 1996.

SENTELHAS, P.S. Estimativa da evapotranspiração de referência com dados de estação meteorológica convencional e automática. Piracicaba, 1998. 97p. Tese (Doutorado) - Escola Superior de Agricultura "Luiz de Queiroz", Universidade de São Paulo. 
SENTELHAS, P.C. Agrometeorologia aplicada á irrigação. In: MIRANDA, J.H.; PIRES, R.C.M. Irrigação. Piracicaba: FUNEP, 2001. 410p. (Série Engenharia Agrícola, 1).

SILVEIRA, P.M. da; STONE, L.F. Manejo da irrigação do feijoeiro: uso do tensiômetro e avaliação do desempenho do pivô central. Brasília: EMBRAPA, SPI, 1994. 46p. (EMBRAPA. CNPAF. Circular Técnica, 27).

SMITH, M. Report on the expert consultation on revision of FAO methodologies for crop water requirements. Rome: FAO, 1991. 45p.

SMITH, M.; ALLEN, R.; PEREIRA, L.S. Revised FAO Methodology for Crop Water Requerements. In: CAMP,C.R.; SADLER, E.J.; YODER, R.E. Evapotranspiration and irrigation scheduling. Texas: ASAE. 1996. p.124 132.

SOARES, W.R. Coeficientes de cultura no estádio de desenvolvimento inicial para diferentes texturas de soos e condições de molhamento. Viçosa, 1999. 67p. Dissertação (Mestrado) - Universidade Federal de Viçosa.

SOEJARDO, D.D.; COMPADRE, C.M.; MEDON, P.J.; KAMATH, S.R.; KINGHORN, A.D. Potencial sweetening agents of plant origin. II Field search for sweet-tasting Stevia species. Economic Botany, v.3, p.71-79, 1983 a.

SOEJARDO, D.D.; COMPADRE, C.M.; KINGHORN, A.S. Ethno-botanical on Stevia. Botanical Museum Leaflets, v.29, n.1, p.1-25, 1983 b. 
SOUSA, J.L.M. de. Evapotranspiração e coeficiente de cultura do algodoeiro submetido a diferentes profundidades do lençol freático. Piracicaba, 1992. 70p. Dissertação (Mestrado) - Escola Superior de Agricultura "Luiz de Queiroz", Universidade de São Paulo.

TANNER, C.B.; JURY, W.A. Estimating evaporation and transpiration from a row crop during incomplete cover. Agronomy Journal, v.68, p.239-242, 1976.

TATEO, F.; MARIOTTI, M.; BONONI, M.; LUBLIN, E.; MARTELLO,S.; CORNARA, T. Contenuto in steviosideo e variabilità morfologica in una popolazione di Stevia rebaudiana (Bert.) Bertoni del Paraguay. Italian Journal of Food Science. v.10, n.3, p.261-267, 1998.

TOZZI, M. Coefficiente colturali del peperone nella zona litoranea della Toscana Settentrionale e verifica funzionale di una semplice attrezzatura per la stima dei consumi idrici delle colture. Pisa, 1995. 76p. Tesi (Laurea) Facultá di Agraria, Università degli Studi di Pisa.

UTUMI, M.M. Deficiências minerais em estévia (Stevia rebaudiana (Bert.) Bertoni): sintomas visuais, composição mineral, crescimento e produção de esteviosídeo. Viçosa, 1994. 101p. Dissertação (Mestrado) - Universidade Federal de Viçosa.

VALADÃO, L.F. Evapotranspiração e coeficiente de cultura do feijoeiro (Phaseolus vulgaris L.) em dois niveis de lençol freático. Botucatu, 1995. 107 p. Dissertação (Mestrado) - Faculdade de Ciências Agronômicas, Universidade Estadual Paulista "Júlio de Mesquita Filho". 
VALIO, I.F.M.; ROCHA, R.F. Effect of photoperiod and growth regulator on growth and floweing of Stevia rebaudiana Bertoni. Japan Journal Crop Science, v.46, p.243-248, 1977.

VERMEIREN, L.; JOBLING, G.A. Irrigação localizada. Roma: FAO, 1980. 184p. (FAO. Irrigação e Drenagem, 36).

VIANA, A.M.; METIVIER, J. Changes in the levels of total soluble proteins and sugars during leaf ontogeny in Stevia rebaudiana Bert. Annals of Botany, v.45, p.4. 1980.

VILLA NOVA, N.A.; REICHARDT, K. Evaporação e evapotranspiração. In: RAMOS, F.; OCCHIPINTI, A.G.; VILLA NOVA, N.A.; REICHARDT, K.; MAGALHÃES, P.C. de; CLEIRU, R.W. (Ed.) Engenharia hidrológica. Rio de Janeiro: UFRJ, 1989. cap.3, p, 143-197.

VILLA NOVA, N.A.; PEREIRA, A.R.; BARBIERI, V. Evapotranspiration as a function of leaf area index and a class $A$ para evaporation. Revista Brasileira de Agrometeorologia, v.4, n.2, p.35-37, 1996.

VILLA NOVA, N.A.; SENTELHAS, P.C. Evaporação máxima de feijoeiro C.V. Goiano Precoce, em função dos dados de área foliar e da evapotranspiração do tanque classe A. In: CONGRESSO BRASILEIRO DE AGROMETEOROLOGIA, 11., Florianópolis, 1999. Anais. Florianópolis: S.B.A., 1999. v.1, p.2192-2198.

VOLTOLINI, J.; SILVA, J.A. Curso sobre manejo da irrigação e manutenção de equipamentos. Florianópolis: EPAGRI, GTZ, 1995. 63p. 
WELLES, J.M.; NORMAN, J.M. Instrument for Indirect Measurement of Canopy Architecture. Agronomy Journal. v.83, n.5, p.818-825. 1991.

WILLIANSON, R.E.; KRIZ, G.E. Response of agricultural crops to flooding, depth of water table, and soil gaseous composition. Transactions of ASAE. v.13, p.216-220, 1970.

WINTER, E.J. A água o solo e a planta: aproveitando os recursos naturais de água para a horticultura. 2.ed. São Paulo: Nobel, 1986. 170p.

ZAIDAN, O. Practices in tomato production. Bet Dagan: MASHAV-CINADCO, 1999. 67p. 
APÊNDICES 
Tabela 14. Dados meteorológicos coletados em junho de 2000 na área experimental.

\begin{tabular}{|c|c|c|c|c|c|c|c|c|}
\hline Dia & Tmax & Tmin & Vento & Rs (W. $\mathrm{m}^{-2} \cdot$ dia) & $\mathrm{Rs}\left(\mathrm{MJ} \cdot \mathrm{m}^{-2} \mathrm{dia}^{-1}\right)$ & UR & UR max. & UR min. \\
\hline 1 & 28,4 & 11,7 & 1,2 & 301 & 26,018 & 75 & 100 & 54 \\
\hline 2 & 28,4 & 13,9 & 1,4 & 305 & 26,364 & 71 & 98 & 48 \\
\hline 3 & 30,9 & 12,5 & 1,1 & 312 & 26,969 & 75 & 99 & 54 \\
\hline 4 & 30 & 14,1 & 1 & 305 & 26,364 & 73 & 100 & 59 \\
\hline 5 & 29,9 & 12,1 & 1,3 & 313 & 27,056 & 68 & 98 & 51 \\
\hline 6 & 29,5 & 14,7 & 1,7 & 257 & 22,215 & 74 & 94 & 60 \\
\hline 7 & 28,7 & 16,4 & 1,6 & 228 & 19,708 & 83 & 100 & 69 \\
\hline 8 & 32,3 & 14,7 & 1,4 & 298 & 25,759 & 73 & 100 & 47 \\
\hline 9 & 32,2 & 16 & 1,2 & 303 & 26,191 & 70 & 96 & 60 \\
\hline 10 & 30,6 & 16,3 & 1,4 & 257 & 22,215 & 81 & 98 & 56 \\
\hline 11 & 19,9 & 17,2 & 2 & 39 & 3,371 & 97 & 100 & 100 \\
\hline 12 & 24,2 & 17 & 1,4 & 127 & 10,978 & 92 & 100 & 83 \\
\hline 13 & 25,6 & 16,3 & 1,1 & 268 & 23,166 & 87 & 100 & 74 \\
\hline 14 & 25,8 & 15,8 & 1,1 & 312 & 26,969 & 87 & 100 & 72 \\
\hline 15 & 25,2 & 16 & 1,6 & 283 & 24,463 & 91 & 100 & 82 \\
\hline 16 & 26,2 & 16,9 & 1,2 & 292 & 25,240 & 92 & 100 & 82 \\
\hline 17 & 31,2 & 17,4 & 1,7 & 281 & 24,290 & 68 & 100 & 45 \\
\hline 18 & 28,3 & 14,4 & 2 & 320 & 27,661 & 54 & 97 & 44 \\
\hline 19 & 31 & 12,1 & 0,9 & 325 & 28,093 & 68 & 99 & 40 \\
\hline 20 & 28,4 & 13,3 & 0,9 & 324 & 28,007 & 72 & 99 & 46 \\
\hline 21 & 29,1 & 13 & 0,9 & 327 & 28,266 & 73 & 100 & 49 \\
\hline 22 & 28 & 12,6 & 0,9 & 324 & 28,007 & 80 & 100 & 100 \\
\hline 23 & 27,6 & 15,5 & 0,8 & 269 & 23,252 & 80 & 100 & 56 \\
\hline 24 & 26,7 & 17,2 & 1,8 & 291 & 25,154 & 81 & 100 & 71 \\
\hline 25 & 25,5 & 17,1 & 1,5 & 197 & 17,029 & 75 & 96 & 66 \\
\hline 26 & 29,2 & 11,9 & 1 & 320 & 27,661 & 74 & 100 & 56 \\
\hline 27 & 26,9 & 14,2 & 1,3 & 313 & 27,056 & 81 & 100 & 64 \\
\hline 28 & 25 & 15,9 & 0,6 & 94 & 8,125 & 92 & 100 & 85 \\
\hline 29 & 27,8 & 16,5 & 1,3 & 311 & 26,883 & 78 & 100 & 60 \\
\hline 30 & 28,8 & 14,5 & 1 & 306 & 26,451 & 79 & 100 & 65 \\
\hline
\end{tabular}

Tmax - temperatura máxima do dia em ${ }^{\circ} \mathrm{C}$; Tmin - temperatura mínima do dia em ${ }^{\circ} \mathrm{C}$; Vento - velocidade do vento em $\mathrm{m} . \mathrm{s}^{-1}$; Rs - radiação solar; UR - umidade relativa do ar média, máxima e mínima em \%, respectivamente. 
Tabela 15. Dados meteorológicos coletados em julho de 2000 na área experimental.

\begin{tabular}{|c|c|c|c|c|c|c|c|c|}
\hline Dia & Tmax & Tmin & Vento & Rs (W.m-2.dia) & $\mathrm{Rs}\left(\mathrm{MJ} \cdot \mathrm{m}^{-2} \mathrm{dia}^{-1}\right)$ & UR & UR max. & UR min. \\
\hline 1 & 28,3 & 16,8 & 0,9 & 288 & 24,895 & 80 & 100 & 60 \\
\hline 2 & 32,1 & 18,2 & 1 & 284 & 24,549 & 80 & 98 & 68 \\
\hline 3 & 33,6 & 16,2 & 1,5 & 227 & 19,622 & 66 & 97 & 52 \\
\hline 4 & 30,4 & 18,5 & 1,5 & 205 & 17,720 & 79 & 99 & 67 \\
\hline 5 & 27,1 & 14,9 & 1,6 & 314 & 27,142 & 78 & 99 & 62 \\
\hline 6 & 30,5 & 13,5 & 0,8 & 313 & 27,056 & 72 & 100 & 46 \\
\hline 7 & 33,8 & 14,8 & 1,2 & 286 & 24,722 & 70 & 95 & 45 \\
\hline 8 & 25,1 & 19,5 & 2,8 & 201 & 17,374 & 77 & 99 & 71 \\
\hline 9 & 27,8 & 14,5 & 1,6 & 314 & 27,142 & 69 & 91 & 58 \\
\hline 10 & 26,1 & 17,7 & 2,8 & 147 & 12,707 & 81 & 99 & 70 \\
\hline 11 & 23,1 & 13,7 & 4,2 & 266 & 22,993 & 77 & 100 & 66 \\
\hline 12 & 21,5 & 11,8 & 1,7 & 183 & 15,819 & 78 & 98 & 66 \\
\hline 13 & 23,5 & 10,1 & 1,4 & 313 & 27,056 & 80 & 100 & 65 \\
\hline 14 & 22,8 & 12,2 & 0,7 & 132 & 11,410 & 89 & 100 & 94 \\
\hline 15 & 24,6 & 14,4 & 2,2 & 289 & 24,981 & 76 & 97 & 70 \\
\hline 16 & 25,1 & 10,2 & 1,3 & 326 & 28,179 & 73 & 100 & 53 \\
\hline 17 & 26,6 & 10,1 & 1 & 319 & 27,574 & 72 & 100 & 51 \\
\hline 18 & 25,6 & 9,8 & 1 & 314 & 27,142 & 73 & 98 & 53 \\
\hline 19 & 25,4 & 12 & 1,2 & 306 & 26,451 & 83 & 100 & 66 \\
\hline 20 & 26,8 & 12,6 & 1,1 & 254 & 21,956 & 80 & 100 & 62 \\
\hline 21 & 31,2 & 12,9 & 0,9 & 305 & 26,364 & 72 & 100 & 38 \\
\hline 22 & 29,3 & 12,2 & 0,9 & 294 & 25,413 & 75 & 100 & 56 \\
\hline 23 & 29,5 & 14,2 & 0,9 & 247 & 21,351 & 75 & 97 & 67 \\
\hline 24 & 27,1 & 18,6 & 2,2 & 103 & 8,903 & 68 & 92 & 65 \\
\hline 25 & 27,6 & 16,8 & 1,6 & 223 & 19,276 & 82 & 99 & 77 \\
\hline 26 & 28,1 & 15,9 & 1,4 & 271 & 23,425 & 85 & 100 & 77 \\
\hline 27 & 28,7 & 16,2 & 0,9 & 297 & 25,673 & 84 & 100 & 64 \\
\hline 28 & 28,3 & 17,5 & 1,2 & 246 & 21,264 & 88 & 100 & 67 \\
\hline 29 & 28,2 & 14,2 & 1,2 & 303 & 26,191 & 80 & 100 & 61 \\
\hline 30 & 29,8 & 12,7 & 1 & 301 & 26,018 & 72 & 100 & 51 \\
\hline 31 & 30,8 & 13,9 & 1,3 & 299 & 25,846 & 60 & 95 & 39 \\
\hline
\end{tabular}

Tmax - temperatura máxima do dia em ${ }^{\circ} \mathrm{C}$; Tmin - temperatura mínima do dia em ${ }^{\circ} \mathrm{C}$; Vento - velocidade do vento em m.s ${ }^{-1}$; Rs - radiação solar; UR - umidade relativa do ar média, máxima e mínima em \%, respectivamente. 
Tabela 16. Dados meteorológicos coletados em agosto de 2000 na área experimental.

\begin{tabular}{|c|c|c|c|c|c|c|c|c|}
\hline Dia & Tmax & Tmin & Vento & Rs (W.m-2.dia) & Rs (MJ.m $\left.\mathrm{m}^{-2} \mathrm{dia}^{-1}\right)$ & UR & UR max. & UR min. \\
\hline 1 & 30,9 & 12,6 & 1 & 299 & 25,846 & 67 & 99 & 47 \\
\hline 2 & 30,3 & 13,7 & 1 & 285 & 24,635 & 77 & 100 & 44 \\
\hline 3 & 30,3 & 14,6 & 0,8 & 253 & 21,869 & 79 & 100 & 55 \\
\hline 4 & 21,3 & 16,6 & 1,1 & 30 & 2,593 & 96 & 100 & 98 \\
\hline 5 & 24,5 & 16,2 & 1,4 & 175 & 15,127 & 86 & 100 & 68 \\
\hline 6 & 25,6 & 12,6 & 1 & 250 & 21,610 & 83 & 100 & 64 \\
\hline 7 & 25,6 & 13,5 & 1,1 & 288 & 24,895 & 85 & 100 & 67 \\
\hline 8 & 28 & 14,2 & 0,9 & 285 & 24,635 & 84 & 100 & 68 \\
\hline 9 & 28,1 & 13,7 & 1,1 & 255 & 22,042 & 82 & 100 & 53 \\
\hline 10 & 28,4 & 14,1 & 1,1 & 276 & 23,857 & 85 & 100 & 61 \\
\hline 11 & 28,4 & 16 & 1 & 268 & 23,166 & 85 & 100 & 59 \\
\hline 12 & 29,5 & 16 & 0,9 & 252 & 21,783 & 82 & 100 & 62 \\
\hline 13 & 32,5 & 15,9 & 0,8 & 226 & 19,535 & 74 & 99 & 49 \\
\hline 14 & 28,9 & 14,7 & 1,2 & 263 & 22,734 & 79 & 99 & 58 \\
\hline 15 & 30,8 & 15,8 & 1 & 268 & 23,166 & 81 & 100 & 65 \\
\hline 16 & 32,7 & 17,1 & 1,1 & 266 & 22,993 & 78 & 100 & 47 \\
\hline 17 & 30,7 & 16,1 & 1,1 & 258 & 22,302 & 85 & 100 & 57 \\
\hline 18 & 32,9 & 16,4 & 0,7 & 255 & 22,042 & 60 & 100 & 49 \\
\hline 19 & 35,2 & 13,9 & 0,8 & 268 & 23,166 & 40 & 100 & 33 \\
\hline 20 & 32,7 & 13,3 & 0,9 & 257 & 22,215 & 84 & 100 & 54 \\
\hline 21 & 34,5 & 14,7 & 0,9 & 241 & 20,832 & 72 & 100 & 46 \\
\hline 22 & 32,6 & 17,5 & 0,9 & 237 & 20,486 & 57 & 98 & 63 \\
\hline
\end{tabular}

Tmax - temperatura máxima do dia em ${ }^{\circ} \mathrm{C}$; Tmin - temperatura mínima do dia em ${ }^{\circ} \mathrm{C}$; Vento - velocidade do vento em $\mathrm{m} . \mathrm{s}^{-1}$; Rs - radiação solar; UR - umidade relativa do ar média, máxima e mínima em \%, respectivamente. 